\title{
38. GEOCHEMISTRY AND ORIGIN OF IGNEOUS ROCKS FROM THE OUTER TONGA FOREARC (SITE 841) ${ }^{1}$
}

\author{
Sherman H. Bloomer, ${ }^{2}$ Anthony Ewart, ${ }^{3}$ Janet M. Hergt, ${ }^{4}$ and Wilfred B. Bryan ${ }^{5}$
}

\begin{abstract}
Two igneous rock units were recovered at Site 841 . More than $200 \mathrm{~m}$ of island-arc rhyolites, rhyolitic tuffs, lapilli tuffs, and pumice breccias, divided into five units, compose the basement at the site. These rhyolitic volcanics are late middle Eocene or older and formed part of a subaerial rhyolitic volcano. These low-K rhyolites were produced by fractional crystallization of a more mafic arc-tholeiitic lava or by dehydration melting of lower crustal arc tholeiites. The Site 841 basement rocks are similar in composition to high- $\mathrm{SiO}_{2}$ lavas in the Eocene basement on 'Eua and crystallized from depleted island-arc-tholeitic basalts like those exposed on 'Eua. No evidence is present in the rhyolites, or in the clasts enclosed within them, for boninite series magmas at Site 841 . The Site 841 rhyolitic complex bears no resemblance to Cretaceous rhyolites from the Lord Howe Rise, which are enriched in $\mathrm{K}$ and incompatible elements. The volcanic rocks at Site 841 are part of a widely distributed Eocene volcanic episode that marked the earliest phases of subduction in the Tonga region; they are not part of an older crustal fragment.

The second igneous sequence is a series of basaltic dikes and sills that intruded Miocene sediments. These basalts have trace element abundances and ratios identical to upper Miocene lavas from the Lau Ridge. The Site 841 basalts do not have any geochemical characteristics that suggest they were generated by unusual thermal conditions in the shallow sub-forearc mantle. They are most reasonably interpreted as intrusions fed by basement dikes propagated from the associated active arc.

No evidence for local serpentinite exposures, like those that are common in the Mariana forearc, was found at Site 841. The results from Site 841 provide strong support for hypotheses of forearc evolution that have been advanced for the Izu-BoninMariana system.
\end{abstract}

\section{INTRODUCTION}

Forearcs are an integral part of intraoceanic convergent margins. Their basement contains a record of the early evolution of the subduction system (e.g., Hussong and Uyeda, 1982; Bloomer, 1983; Taylor, 1992) and the volcaniclastic sediments covering them document the tectonic and geochemical evolution of the arc.

Marine geologic studies and Deep Sea Drilling Project (DSDP) and Ocean Drilling Program (ODP) transects of the intraoceanic IzuBonin-Mariana (IBM) forearcs have generated four important new ideas about the origin and evolution of these terranes. The first, and most striking, is the recognition that the initial phases of volcanism in these subduction zones developed nearly synchronously in the middle to late Eocene over a zone up to $300 \mathrm{~km}$ wide (Taylor, 1992) and thousands of kilometers long (Stern and Bloomer, 1992; Taylor, 1992). This early, or "infant," arc volcanism was characterized by the eruption of very depleted boninitic and arc-tholeiitic lava compositions (e.g., Meijer, 1980; Ishii, 1985; Bloomer, 1987; Murton et al., 1992) and developed in an extensional setting (as evidenced by dikes on Chichijima in the Bonin Islands; Umino, 1985), in places possibly to the point of true seafloor spreading (Stern and Bloomer, 1992). This mode of arc volcanism is unlike that developed during the "normal" or mature phases of arc activity and is a plausible mechanism for developing supra-subduction zone ophiolites (what Pearce et al. [1984] termed "pre-arc" ophiolites; Robertson, 1990; Stern and Bloomer, 1992).

A second new observation is that the exposure of Eocene arc basement immediately adjacent to the axis of the Mariana-Bonin

\footnotetext{
'Hawkins, J., Parson, L., Allan, J., et al., 1994. Proc. ODP, Sci. Results, 135: College Station. TX (Ocean Drilling Program).

2Department of Earth Sciences, Boston University, Boston, MA 02215, U.S.A.

${ }^{3}$ Department of Geology and Mineralogy. University of Queensland. St. Lucia, Brisbane, Queensland, 4067. Australia.

${ }^{4}$ Department of Earth Sciences. The Open University, Walton Hall, Milton Keynes, MK7 6AA, United Kingdom (present address: School of Earth Sciences. The University of Melbourne, Parkville, Victoria, 3052, Australia).

${ }^{5}$ Department of Geology and Geophysics. Woods Hole Oceanographic Institution. Woods Hole, MA 02543, U.S.A.
}

Trench requires some subduction erosion since the Eocene (Hussong and Uyeda, 1982; Bloomer, 1983). However, if the Eocene basement did form by unusual, voluminous volcanism in an extensional environment, the required amount of erosion may only be $20-50 \mathrm{~km}$ (Johnson et al., 1991; Stern and Bloomer, 1992; Taylor, 1992). Clear evidence is also present of episodic, post-Eocene accretion of Pacific Plate sediments and crustal fragments to the outer forearc (Karig and Ranken, 1983; Bloomer, 1983; Johnson et al., 1991).

The large volume of serpentinite in the outer forearc has been a surprising discovery. The serpentinites occur as diapirs, with associated serpentine mud flows (Fryer et al., 1985; Bloomer, 1983). Porewater geochemical studies suggest that the fluids responsible for the serpentinization are derived in part by dehydration of the downgoing slab (Haggerty, 1987; Mottl et al., 1989).

Finally, the drilling transects documented episodes of magmatic rejuvenation in supposedly "cold" forearcs. Sills and dikes cutting Miocene and younger sediments were found in two holes drilled in the outer Mariana-Bonin forearc (Shipboard Scientific Party, 1990a, 1990b). These intrusions were emplaced in the forearc at a time when the active arc was well to the west, and indicate either a reheating of the forearc or intrusion of long dikes and sills from the active arc. Leg 126 also found evidence for rifting and volcanism within the IzuBonin forearc during the Oligocene, at a time when the main active arc farther to the west (Taylor, 1992).

These observations in the Izu-Mariana-Bonin system have painted a far different picture of intraoceanic forearcs than existed $11 \mathrm{yr}$ ago when the results of DSDP Leg 60 documented in-situ Eocene boninitic basement in the outer Mariana forearc (Hussong and Uyeda, 1982). These forearcs are geologically complex, and are clearly direct products of subduction, not just trapped pieces of oceanic crust. They have geologic and geochemical similarities to supra-subduction zone ophiolites like those in Troodos and Oman and represent a previously unappreciated type of crustal construction.

Before Leg 135, it was not known whether the hypotheses of forearc evolution derived from the IBM studies were generally applicable to other intraoceanic forearcs. Seismic and dredging studies in the Tonga forearc had suggested that arc basement did occur in the 
outer forearc (cf. Fisher and Engel, 1969; Bloomer and Fisher, 1987), but there were not good constraints on the age and composition of this basement. Site 841 was drilled just west of the outer trench-slope break to determine the age and composition of the forearc basement and to examine the evolution of the Tonga forearc as a test of the hypotheses proposed for the Izu-Marian-Bonin system. A second objective at the site was to recover the volcaniclastic sediments overlying the basement to constrain the variation of arc volcanic compositions through time and the uplift and subsidence history of the forearc.

Two igneous sequences were recovered from Hole $841 \mathrm{~B}$. The uppermost is a series of basaltic dikes and sills intruded into Miocene sediments and the lower one is a sequence of low-K rhyolitic tuffs, rhyolites, and pumice breccias that constitute the forearc basement at this location. This silicic complex is older than late middle Eocene, as there are late middle Eocene calcareous volcanic sandstones, containing rhyolitic clasts, normally faulted against the volcanics.

The purpose of this paper is to present detailed geochemical analyses of the two major igneous groups from Hole $841 \mathrm{~B}$ and to examine the tectonic implications of their compositions. We will also draw some comparisons with the evolution of the Izu-Mariana-Bonin forearc.

\section{BACKGROUND}

\section{Regional Geology}

The Tonga forearc is a part of a complex array of arcs and backarcs that have developed as a result of the subduction of the Pacific Plate below the Indo-Australia Plate since at least middle Eocene time (e.g., Herzer and Exon, 1985). This subduction is presently near perpendicular to the trench at a rate of about $16 \mathrm{~cm} / \mathrm{yr}$ (including an $8 \mathrm{~cm} / \mathrm{yr}$ opening rate in the Lau Basin; Pelletier and Louat, 1989). There are two chains of islands parallel to the trench (Fig. 1), separated from each other by the deep, sedimented Tofua Trough (Raitt et al., 1955). The eastern chain, the Tonga platform, includes extinct, corallinecapped Eocene to Miocene volcanic islands and the western chain, the Tofua Arc, comprises active submarine and subaerial volcanoes erupting basalt, basaltic andesite, and minor dacite (e.g., Ewart et al., 1977). West of the Tofua Arc lies the actively spreading Lau Basin. which is bounded on the west by the inactive Lau Ridge, a remnant arc (Cole et al., 1990).

The Tonga forearc and platform have existed since Eocene time, when they formed as part of the ancient Melanesian arc, which included fragments of what are now the Fiji, Lau, Tonga, and New Hebrides arcs. The development of the subduction zones associated with these arcs was preceded by rifting of the eastern Australian margin in Late Cretaceous time; the Lord Howe Rise and the Norfolk Ridge are blocks of this margin that were rafted to the east (Burns and Andrews, 1973). These ridges were separated from the margin by seafloor spreading in the New Caledonia Basin in late Paleocene time and in the Tasman Basin and Coral Sea through early Eocene time (Bentz, 1974).

The west-dipping subduction that built the Melanesian arc was initiated sometime after the early Eocene (Herzer and Exon, 1985). The early growth of the arc was accompanied by spreading in the South Fiji Basin, which continued until about $26 \mathrm{Ma}$ (Malahoff et al., 1982). The New Hebrides arc separated from the Lau-Fiji-Tonga arc during the late Miocene, after the initiation of an east-dipping subduction zone beneath the New Hebrides arc (Herzer and Exon, 1985). Volcanism in the Tonga system continued through the Miocene, along the Lau Ridge. The Tonga platform accumulated a thick clastic sedimentary cover during the Miocene, as it was the forearc east of the active Lau Ridge (Herzer and Exon, 1985). This forearc sedimentary fill is cut locally by Miocene dikes and sills (21.3 and 13.9 Ma; Cunningham and Anscombe, 1985). The main phase of this period of arc volcanic activity is represented by the Lau Group volcanics on the Lau Ridge (Cole et al., 1985). A regional unconformity developed over the Tonga platform in the late Miocene or early Pliocene, as a consequence of uplift associated with the initiation of spreading in the Lau Basin (Herzer and Exon, 1985; Packham, 1985). This opening

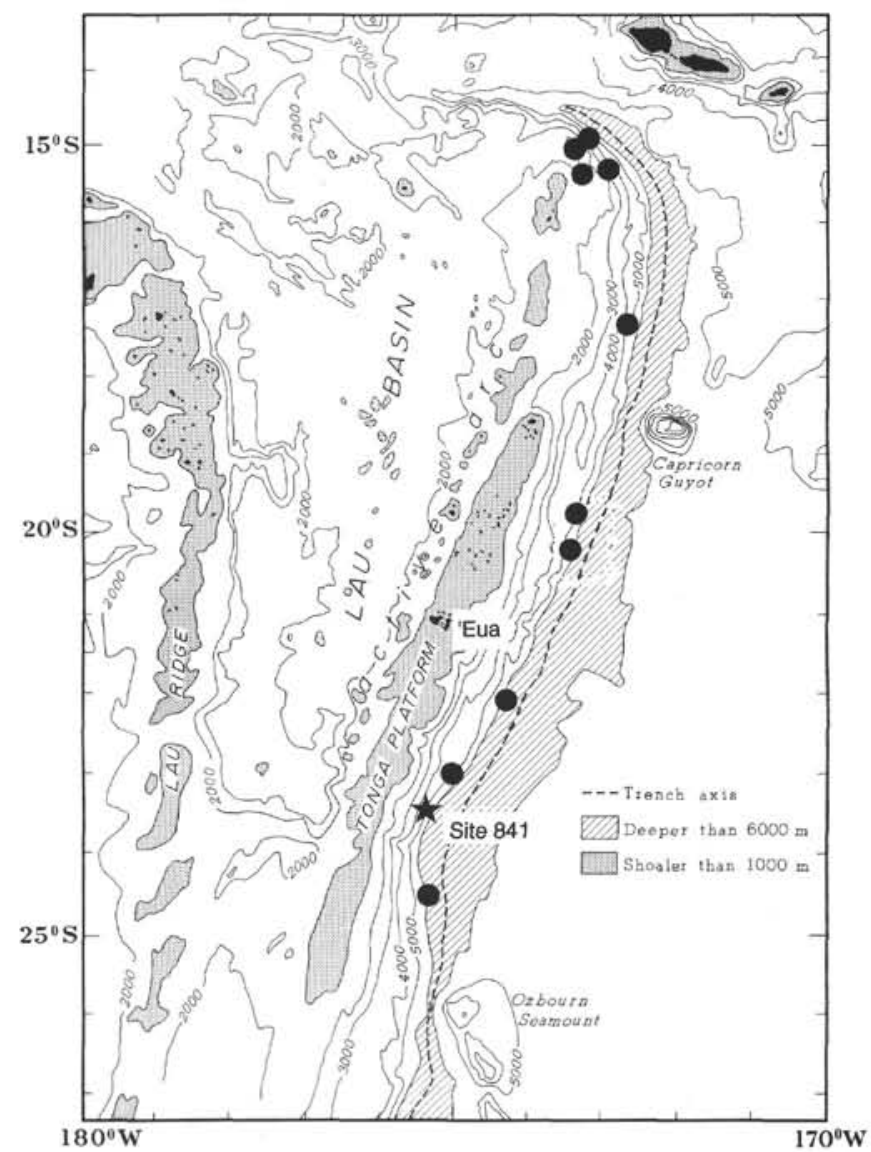

Figure 1. Location of Site 841 (star). Filled circles show places where volcanic or plutonic rocks of island arc affinities have been dredged from the forearc and trench slope (Fisher and Engel, 1969; Bloomer and Fisher, 1987; Vallier, O'Connor, et al., 1985; Gnibidenko et al., 1985; Sharaskin et al., 1983; Falloon et al., 1987). Bathymetry in meters.

of the Lau Basin about 6 Ma ago (Parson, Hawkins, Allan, et al., 1992) split the Lau Ridge from the Tonga Platform and led to the development of the presently active arc to the west of the Tonga platform (Fig. 2). Volcanism continued on the Lau Ridge till about 2.4 Ma, as the Lau Basin opened. This volcanism produced the Korobasaga Group, a large-ion-lithophile-enriched, slightly alkalic, arc series (Cole et al., 1985). The opening of the Lau Basin has rafted the Tonga platform to the east, and rotated the entire forearc clockwise (see Sager and MacLeod, this volume).

\section{Forearc Geology}

The forearc is flanked on the west by the Tonga platform, an inactive frontal arc now covered by a thick sedimentary sequence (Fig. 1). The basement of the Tonga platform is exposed only on the island of 'Eua (Fig. 1). That basement comprises depleted island-arctholeiitic basalts, andesites, and dacites (Ewart and Bryan, 1972; Hawkins and Falvey, 1985; Cunningham and Anscombe, 1985). The basement rocks yield radiometric ages of 46 to $40 \mathrm{Ma}$ (Ewart et al., 1977; Duncan et al., 1985) and, locally, are unconformably overlain by upper middle Eocene calcareous conglomerates and breccias (Cunningham and Anscombe, 1985). Oligocene lava flows (33-31 Ma) and Miocene dikes (19-17 Ma) indicate later episodes of arc activity (Duncan et al., 1985) that predate the opening of the Lau Basin when the Tonga platform was still part of the Lau Ridge.

Seismic reflection profiles suggest that the Eocene basement on 'Eua can be traced across the forearc and crops out on the landward 


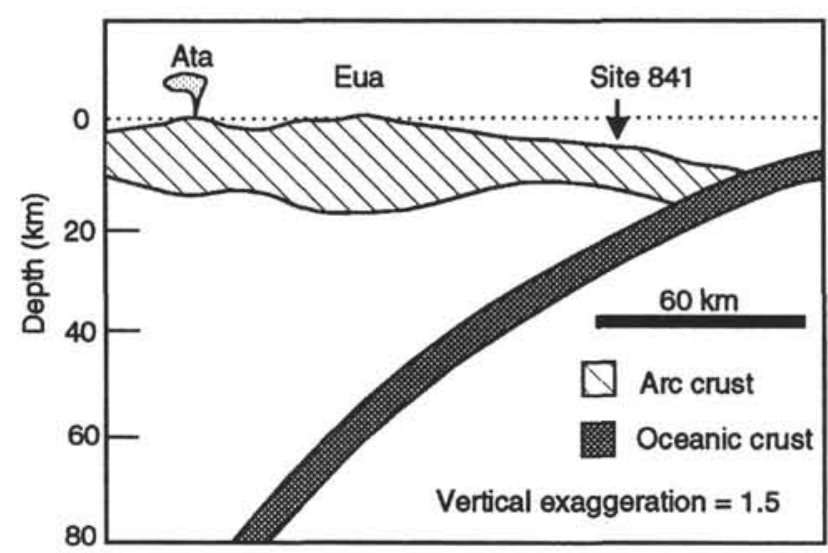

Figure 2. Schematic cross section of the Tonga forearc showing the relative positions of 'Ata, the active arc, 'Eua, on the eastern Tonga Ridge, and Site 84I on the trench-slope break. Crustal thicknesses are roughly after Raitt et al. (1955); these are not well constrained. Depth to Benioff zone from Billington (1980).

trench slope, just outboard of the trench-slope break (Greene and Wong, 1983; Gnibidenko et al., 1985). Fragments of arc-tholeiitic basalts and andesites, boninites, highly depleted serpentinites, and gabbros have been dredged from a number of places on the landward slope (Fig. 1) supporting this suggestion that the entire forearc is floored by arc crust. The age of the outer forearc basement is not constrained by these dredge samples. Boninite glasses from the northern trench have yielded ages of $<10 \mathrm{Ma}$ (A. Crawford, pers. comm., 1992), but gabbroic rocks from the same suite have a $50 \mathrm{Ma}$ age (Acland et al., 1992). Boninitic glasses commonly yield anomalously young ages (Tsunakawa, 1983); the boninites at the northern trench slope are in a complicated region at the terminus of the active arc and Lau Basin, along a trench-trench transform. They may indeed be young, but their tectonic significance is difficult to assess at present. This ambiguity concerning the age of the forearc basement made one of the principal objectives of Site 841 to determine the basement age in a portion of the forearc that has undergone only normal convergence and is well-removed from the loci of Oligocene and younger arc volcanism.

The exposure of arc volcanic rocks in the mid- and upper-landward trench slopes has been taken as evidence for subduction erosion of the forearc (Bloomer and Fisher, 1987; Vallier, O'Connor, et al., 1985) since such exposures are unlikely to have been generated in situ. Lonsdale (1986) has postulated that subduction erosion has been accelerated by the passage of the Louisville Ridge southward along the forearc. There has been, however, minor accretion of seamount fragments and offshore pelagic sediments to the lower landward slopes (Bloomer and Fisher, 1987; Vallier, O'Connor, et al., 1985).

The forearc has been affected by a number of tectonic events. Drilling at Site 840 on the Tonga platform documented two periods of rapid subsidence on the crest of the ridge, one after $9 \mathrm{Ma}$, coinciding with the breakup of the Melanesian Arc, and one dating from 5.25 $\mathrm{Ma}$, related to arc rifting during the opening of the Lau Basin (Clift, this volume). The passage of the Louisville Seamount Chain southward down the forearc does not appear to have produced any documentable uplift or subsidence in the forearc (Clift, this volume), though it does appear to have produced some faulting and fracturing of the forearc (Gnibidenko et al., 1985; Bloomer et al., 1988).

\section{Site 841}

Site 841 was located just west of the trench-slope break (Figs. $1-2), 48 \mathrm{~km}$ inboard of the axis of the Tonga Trench, $140 \mathrm{~km}$ outboard of the active arc island of 'Ata, and about $70 \mathrm{~km}$ outboard of the eastern edge of the Tonga platform (the equivalent position of 'Eua). The major objective for the site was to determine the age and composition of the forearc basement, to develop a model for the origin of

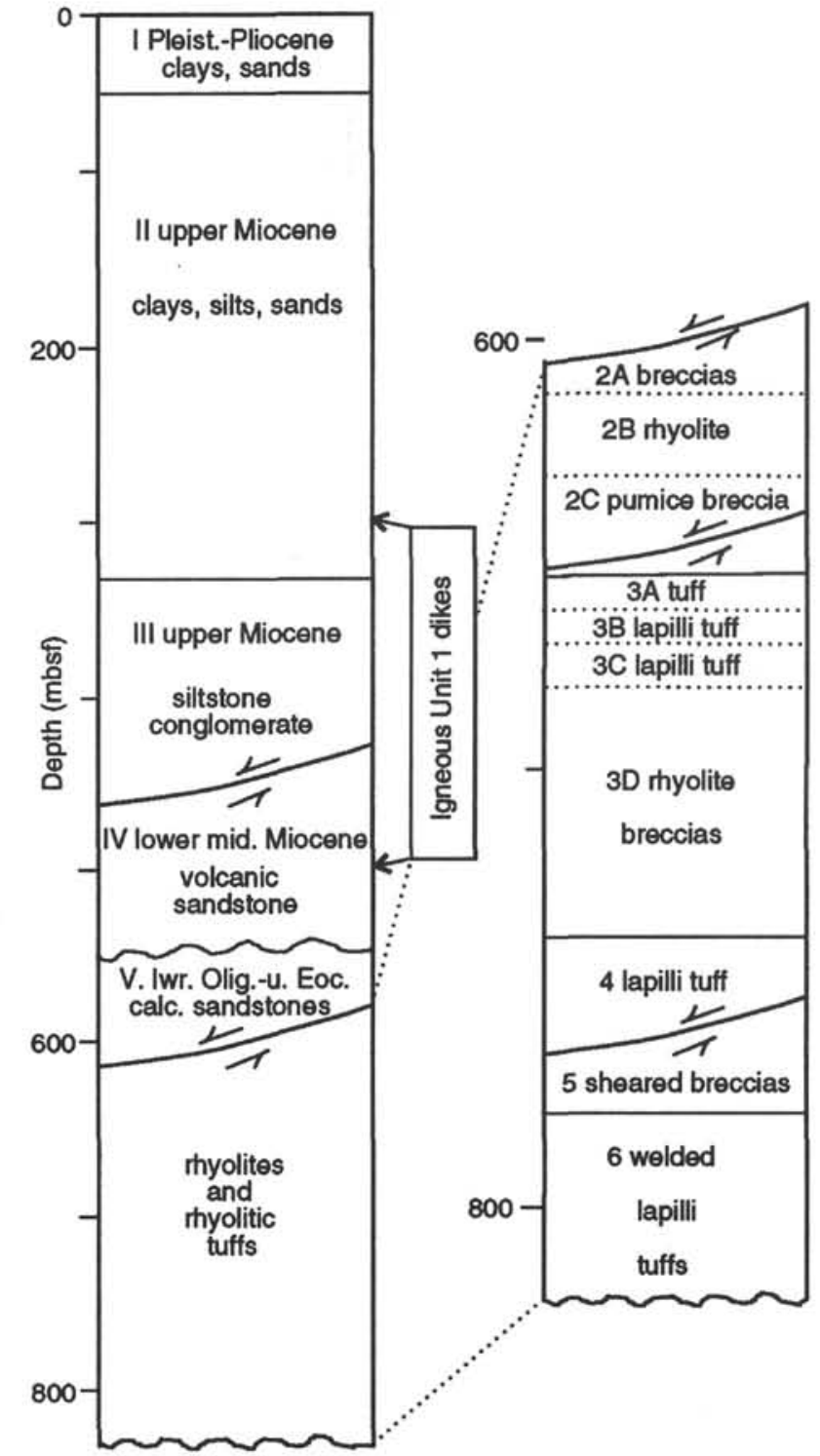

Figure 3. Schematic stratigraphy of the principal sedimentary and igneous units found at Site 841 (from Shipboard Scientific Party, 1992).

the forearc, and to compare the evolution of the Tonga forearc to hypotheses of forearc evolution derived in the IBM region. A secondary objective was to recover the overlying sedimentary section, which could be used to understand the tectonic history of the forearc and the geochemical evolution of the adjacent island arc.

Hole $841 \mathrm{~B}$ penetrated $834.2 \mathrm{mbsf}$ in a water depth of $4810 \mathrm{~m}$. The $210.55 \mathrm{~m}$ of drilled igneous basement (with about $14 \%$ recovery) at the site is composed of low-K rhyolites, rhyolitic tuffs, breccias, welded tuffs, and lapilli tuffs (Fig. 3). The welded fragments, the absence of interbedded sediments and marine fauna, and the lack of density sorting within the pumice breccias indicate a subaerial origin for the rhyolitic complex. Two possibilities were considered for the origin of this complex (Parson, Hawkins, Allan, et al., 1992). First, this could be an Eocene construct equivalent to the rocks that are exposed on 'Eua. Alternatively, the Site 841 basement could be a fragment of a rifted block like the Cretaceous $(93.7 \pm 1.2 \mathrm{Ma}$; van der Lingen, 1973) Lord Howe Rise, which also comprises high-silica lapilli tuffs and rhyolites. Preliminary K-Ar dating of one of the rhyolites yielded ages of 44 and $45 \mathrm{Ma}$, and a suspect date of $67 \mathrm{Ma}$ (see McDougall, this volume). Illites from the rhyolitic tuffs yield 
K-Ar ages of 52.8,51.4 and 31.2 Ma (D. Schöps, pers. comm., 1993). These ages cluster in the Eocene, supporting the former hypothesis (see McDougall, this volume).

Fifty-five $\mathrm{m}$ of Eocene and lower Oligocene calcareous volcanic sandstones, with basal ages of about 41.3 Ma (foraminifer Zone P14: Parson, Hawkins, Allan, et al., 1992), are faulted against the silicic basement. This fault strikes north to northeast and dips east at about $10^{\circ}-30^{\circ}$ (see MacLeod, this volume). Parasitic structures are consistent with normal motion on this fault. The fauna in the Eocene sediments indicate very shallow-water (photic zone) depositional conditions (see Chaproniere, this volume). In combination with the evidence for subaerial eruption of the rhyolitic basement complex, it is clear that the basement at Site 841 has subsided over $5000 \mathrm{~m}$ since the late Eocene.

The Eocene-Oligocene sediments are overlain by $91 \mathrm{~m}$ of lower middle Miocene turbiditic sandstones and siltstones; these are unconformably overlain by $125 \mathrm{~m}$ of upper Miocene siltstones, sandstones, and volcanic conglomerates, some with reworked Eocene fauna, and $277 \mathrm{~m}$ of late Miocene vitric silts and sandstones. This Miocene section is intruded by several orthopyroxene-clinopyroxene-plagioclase-phyric basaltic dikes and sills. Fifty-six $m$ of Pleistocene to Pliocene clays, sands, and ashes cap the section. The entire sedimentary sequence is cut by microfaults, most of which are normal faults, although minor reverse faults also occur (see MacLeod, this volume). Two major faults cut the sections at $449-458$ and 605 mbsf. The upper faults dips about $60^{\circ}$, has a normal displacement, and may have accommodated over $1 \mathrm{~km}$ of motion (see MacLeod, this volume). The lower fault separates the Eocene calcareous sediments from the rhyolitic basement.

The two igneous groups at the site-the intrusives into the Miocene sediments and the pre-late Eocene rhyolitic basement-record two different magmatic pulses in the history of the Tonga forearc. We will examine the geochemistry and significance of each igneous group separately.

\section{METHODS}

Major and trace element data reported here for igneous rocks from Site 841 are from the JOIDES Resolution shipboard analyses, Boston University, the Woods Hole Oceanographic Institution, the University of Durham, the University of Queensland, Monash University, and the Australian National University. Shipboard analyses were by Xray fluorescence (XRF); methods are discussed in Parson, Hawkins, Allan, et al. (1992). Samples were ignited at $1100^{\circ} \mathrm{C}$ before being analyzed. A discussion of shipboard precision and sample contamination during grinding are presented in Hergt and Sims (this volume).

Analyses at the Woods Hole Oceanographic Institution are of whole-rock powders by XRF. Techniques are discussed in Bryan et al. (this volume). Samples were ignited before being analyzed. Analyses from the University of Queensland for major elements and for Rb, $\mathrm{Zr}, \mathrm{Zn}, \mathrm{Y}, \mathrm{Ni}, \mathrm{Cr}, \mathrm{V}, \mathrm{Sc}, \mathrm{Co}, \mathrm{Cu}$, and $\mathrm{Zn}$ were also by XRF. Be and $\mathrm{Na}$ on the same samples were determined by atomic absorption spectrometry; some of these samples were analyzed for rare earths by instrumental neutron activation analysis (INAA) at the Australian National University (B.W. Chappell, analyst) and for rare-earth elements (REEs), Cs, Ba, Nb, U, Th, Pb, Ta, Hf, W, Tl, and Ga by inductively coupled plasma source mass spectrometry (ICP-MS) at Monash University (W.W. Ahlers, analyst). Samples were ignited before being weighed and analyzed. All analyses were of bulk-rock powders, except for the analysis of Sample 135-841B-50R-1,5-9 cm, which was of glass separated from a plagioclase-quartz phyric pitchstone. Details of the analytical methods and errors are included in Ewart et al. (this volume).

Analyses from the University of Durham were of glass separates and were done by ICP-MS. The methodology is given in Hergt and Nilsson (this volume). Samples were not ignited before being analyzed and major element analyses were normalized to $100 \%$.
Analyses from Boston University were by inductively coupled plasma emission (ICP) spectrometry. Samples were dried at $110^{\circ} \mathrm{C}$ before being weighed, but they were not ignited. Loss on ignition (LOI) was not determined for the samples because of the small size of many of them. Analyses of samples from Sections 135-841B-57R1 and -59R-1 were of whole-rock samples crushed in diamonite mortars. Glass was separated from a pitchstone from Section 135 841B-47R-2; analyses from Sections 135-841B-23R-4, -25R-4, and $-26 \mathrm{R}-2$ are of hand-picked separates from crushed and sieved bulk rock. This separation was done to try to remove the ubiquitous siliceous and carbonate veining in the dike and sill samples. The cleaned samples were powdered in a diamonite mortar, dried at $110^{\circ} \mathrm{C}$, and mixed 1:3 with a lithium metaborate flux. The mixtures were fused at $1000^{\circ} \mathrm{C}$ for $20 \mathrm{~min}$ and the glasses then dissolved in $50 \mathrm{~mL}$ of $10 \%$ $\mathrm{HNO}_{3}$. These solutions were used for trace element determinations; major elements were determined on $1-\mathrm{mL}$ aliquots from the trace element solutions, which were diluted with $25 \mathrm{~mL}$ of $10 \% \mathrm{HNO}_{3}$ and spiked with $\mathrm{Li}_{2} \mathrm{CO}_{3}$ as a matrix modifier. Standard curves were calculated using aqueous standards and USGS reference rock powders.

A number of small volcanic rock inclusions from the sedimentary section and from the igneous basement were analyzed at Boston University. These inclusions range from large clasts (over $1 \mathrm{~g}$ ) to small, individual grains picked from crushed sediment or basement samples. The latter were as small as $1 \mathrm{mg}$. These samples were crushed in a diamonite mortar, or if less than $0.1 \mathrm{~g}$, simply mixed directly with lithium metaborate flux, after being washed and dried. A flux:rock ratio of $3: 1$ was used for samples larger than $0.02 \mathrm{~g}$; these mixtures were fused and dissolved at 50:1 in dilute nitric acid. Smaller samples were mixed with $0.05 \mathrm{~g}$ flux and dissolved in $13 \mathrm{~mL}$ of solution. Some of the solutions were too dilute to obtain reliable minor and trace element analyses. Weighing errors for the very small samples produced sums ranging from $90 \%$ to $117 \%$. Sums outside this range were discarded, and sums less than $95 \%$ and greater than $105 \%$ were then normalized to $100 \%$.

Analyses of interlaboratory reference powders, prepared aboard ship in an agate mill, are listed in Table 1. The analyses from the different laboratories and different techniques generally agree very well. Also listed are analyses of USGS reference rocks W-2 and BHVO, and an estimate of precision for the Boston University lab, based on replicate analyses of the interlaboratory reference powders.

The $\mathrm{Pb}-, \mathrm{Nd}-$, and $\mathrm{Sr}$-isotopic analyses were performed at the Open University. Techniques are described in Hergt and Hawkesworth (this volume).

Analyses of rocks from Site 841 are plotted normalized to normal mid-ocean-ridge basalt (N-MORB) compositions in several figures. The normalizing values used are from Sun and McDonough (1989).

\section{POST-LATE MIOCENE DIKES AND SILLS (UNIT 1) Description}

Nine intervals of basalt, ranging in thickness from $7 \mathrm{~cm}$ to $18 \mathrm{~m}$, were drilled within Miocene sediments between 324.76 and 497.68 mbsf. These basalts are petrographically similar and were denoted as Subunits IA through II. The basalt-sediment contacts, when recovered, are near horizontal to steeply dipping. Contacts include glassy margins on basalts, brecciated hyaloclastite zones, and baked sediments, suggesting that the units are dikes and sills rather than flows. Subunits $1 \mathrm{~A}-1 \mathrm{G}$ are intruded into upper Miocene sediments. Subunit $1 \mathrm{H}$ occurs as broken fragments at the base of a major fault that juxtaposes upper Miocene and lower middle Miocene sediments. Subunit $1 \mathrm{I}$ is within lower mid-Miocene sediments.

Formation MicroScanner (FMS) records show that the distribution of the basaltic sills and dikes is more complex than shown by the recovered core. For example, Subunit ID was defined as a $17-m$-thick sill between 383 and 400 mbsf. The FMS images show that the unit actually occurs between 380 and 396 mbsf as 11 individual intrusions with thicknesses from 5 to $134 \mathrm{~cm}$. The contacts of the dikes strike 


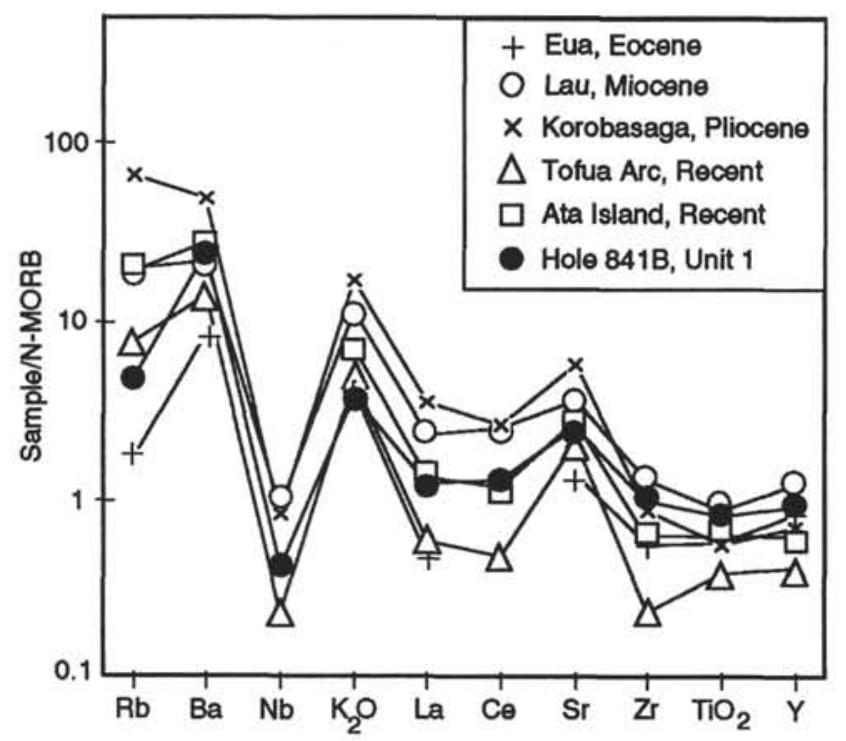

Figure 4. Comparison of compositions of average Unit 1 basalt with arc volcanic units in the Tonga region with $52 \%-56 \% \mathrm{SiO}_{2}$, normalized to $\mathrm{N}$ MORB (values from Sun and McDonough, 1989). Analyses from 'Eua from Cunningham and Anscombe (1985) and Hawkins and Falvey (1985); Lau and Korobasaga analyses from Cole et al. (1985); Tofua Arc (active arc) average compositions from Ewart and Hawkesworth (1987), and average for 'Ata Island (active arc) from Vallier, Stevenson, Scholl et al. (1985).

$211^{\circ}$ to $31^{\circ}$ and, with one exception, dip toward the trench at $2^{\circ}$ to $59^{\circ}$ (see MacLeod, this volume; dips are calculated after rotation of sedimentary layering to horizontal).

The sills and dikes are orthopyroxene-clinopyroxene-plagioclase phyric basalts. Plagioclase is the dominant phenocryst, constituting 4-12 modal \%. Clinopyroxene ranges from trace amounts to 5 modal $\%$ and up to 2 modal\% orthopyroxene was found, though it is absent in some samples. The basalts have $3 \%-5 \%$ vesicles, which tend to be concentrated toward the contacts of the intrusions. A detailed petrography of each subunit can be found in Parson, Hawkins, Allan, et al. (1992).

Most of the samples have been affected by a low-temperature alteration. Siliceous, carbonate, $\mathrm{K}$-feldspar, and thaumasite veins are common. Minor amounts of sulfides, principally pyrite, are developed in some of the veins. The groundmass is typically $5 \%-50 \%$ replaced by clays, chlorite, and zeolites. The basalt in Subunit II is unusual in its lack of alteration.

\section{Geochemistry}

Eleven different sill or dike samples were analyzed; all are from the intrusions in upper Miocene sediments. $\mathrm{SiO}_{2}$ ranges from $50 \%$ to $54 \%$; the shipboard analyses appear to be high in comparison with the Queensland and Boston University analyses, even with corrections for LOI (Table 2). The average composition for the intrusions is $51.7 \% \mathrm{SiO}_{2}$, including the shipboard analyses, and the samples should be referred to as basalts (Le Bas et al., 1986).

All of the samples have essentially identical compositions, within interlaboratory errors (Tables $2-3$ ). The samples are relatively enriched in $\mathrm{Ba}, \mathrm{K}$, and $\mathrm{Sr}$; they are depleted in $\mathrm{Nb}$ and $\mathrm{Ta}$; and they have slight light-rare-earth-element (LREE) depletions (Fig. 4 and Table 2). Their very similar compositions support the shipboard conclusion, based on petrography, that the individual basalts are all part of a single intrusive event. There are no analyses from Subunits $1 \mathrm{C}, 1 \mathrm{G}, 1 \mathrm{H}$, or 1I, but their igneous mineralogy and textures are identical to the analyzed basalts; we interpret them to be part of the same intrusive episode.

Three of the basalt samples have Ba concentrations greater than $250 \mathrm{ppm}$, and $\mathrm{Ba}$ in general varies more than other elements (Table 2). The three high-Ba samples are all noted as being extensively veined;
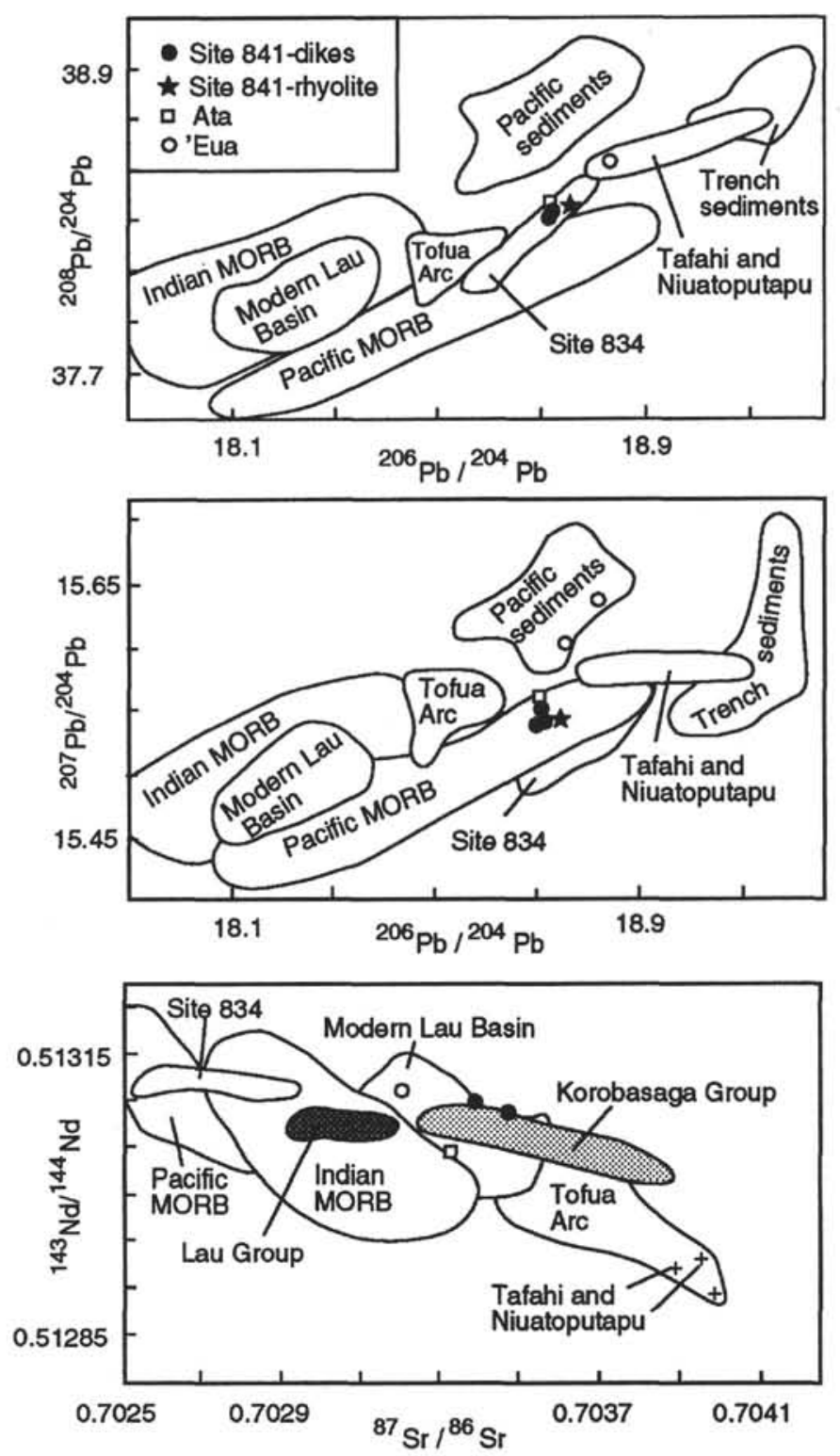

Figure 5. Isotopic compositions of Site 841 igneous rocks compared to fields for Pacific and Indian MORB, modern Lau Basin Basalts, the southern Tonga Arc (Tofua Arc), Tafahi Island (northern Tonga Arc), and Pacific and Tonga Trench sediments. For a discussion of the analytical methods and sources of reference fields, see Hergt and Nilsson (this volume). Dark-shaded Sr-Nd field $=$ Lau Group volcanics, and light-shaded field = Korobasaga Group (both from Cole et al., 1990).

the high $\mathrm{Ba}$ concentrations are likely a consequence of alteration, perhaps from the development of authigenic alkali feldspar veins.

The compositions of the basalt intrusives are typical for arc volcanics of all ages from the Tonga system (Fig. 4 and Table 3). They have the same element enrichments and depletions and fall well within the range of arc compositions of similar $\mathrm{SiO}_{2}$. Their isotopic ratios are within the range of modern Tonga Arc and Lau Basin basalts (Table 4 and Fig. 5) and do not show a pronounced sediment contamination signature (see Hergt and Nilsson, this volume). Their elemental and isotopic compositions indicate that the Unit 1 basalts, like most arc lavas in the Tonga region, are fractionates of mantle-derived melts.

The Unit 1 basalts are not as depleted in large-ion-lithophile elements (LILEs) and high-field-strength elements (HFSEs) as are the Eocene lavas on 'Eua (Table 3). Neither are the basalts as depleted as 
Table 1. Comparison of major and trace element analyses of shipboard powders (ground in agate) used for interlaboratory comparison.

\begin{tabular}{|c|c|c|c|c|c|c|c|c|c|c|c|c|c|}
\hline \multirow{2}{*}{$\begin{array}{l}\text { Sample } \\
\text { Laboratory } \\
\text { Method }\end{array}$} & \multicolumn{2}{|r|}{ W-2 } & \multicolumn{2}{|c|}{ BHVO } & \multirow{2}{*}{$\begin{array}{c}\begin{array}{c}\text { Precision of } \\
\text { replicates }\end{array} \\
\text { BU } \\
\text { ICP }\end{array}$} & \multicolumn{4}{|c|}{$135-834 \mathrm{~B}-33 \mathrm{R}-2,105-110 \mathrm{~cm}$} & \multicolumn{4}{|c|}{$135-836 \mathrm{~B}-5 \mathrm{R}-2,65-74 \mathrm{~cm}$} \\
\hline & $\begin{array}{l}\text { BU } \\
\text { ICP }\end{array}$ & Reported & $\begin{array}{l}\mathrm{BU} \\
\mathrm{ICP}\end{array}$ & Reported & & $\begin{array}{c}\text { Queensland } \\
\text { XRF, AA }\end{array}$ & $\begin{array}{l}\text { WHOI } \\
\text { XRF }\end{array}$ & $\begin{array}{l}\mathrm{BU} \\
\mathrm{ICP}\end{array}$ & $\begin{array}{l}\text { Durham } \\
\text { ICP-MS }\end{array}$ & $\begin{array}{l}\text { Queensland } \\
\text { XRF, AA }\end{array}$ & $\begin{array}{l}\text { WHOI } \\
\text { XRF }\end{array}$ & $\begin{array}{l}\mathrm{BU} \\
\mathrm{ICP}\end{array}$ & $\begin{array}{l}\text { Durham } \\
\text { ICP-MS }\end{array}$ \\
\hline \multicolumn{14}{|c|}{ Major elements (wt\%): } \\
\hline $\mathrm{SiO}_{2}$ & 52.84 & 52.81 & 49.16 & 49.90 & 0.32 & 49.32 & 49.56 & 48.64 & - & 49.45 & 49.30 & 48.21 & - \\
\hline $\begin{array}{l}\mathrm{TiO}_{2}^{-} \\
\mathrm{Al}_{2} \mathrm{O}_{3}\end{array}$ & $\begin{array}{r}1.04 \\
15.49\end{array}$ & $\begin{array}{r}1.06 \\
15.49\end{array}$ & $\begin{array}{r}2.90 \\
13.47\end{array}$ & 2.69 & 0.01 & 1.27 & 1.23 & 1.24 & 1.18 & $\begin{array}{r}0.83 \\
15.95\end{array}$ & $\begin{array}{r}0.78 \\
15.82\end{array}$ & 0.83 & 0.81 \\
\hline $\begin{array}{l}\mathrm{Al}_{2} \mathrm{O}_{3} \\
\mathrm{Fe}_{2} \mathrm{O}_{3} \mathrm{y}\end{array}$ & $\begin{array}{l}15.49 \\
10.54^{*}\end{array}$ & $\begin{array}{l}15.49 \\
1086^{*}\end{array}$ & $\begin{array}{l}13.47 \\
12.29 *\end{array}$ & $\begin{array}{l}13.85 \\
12.23 *\end{array}$ & $\begin{array}{l}0.06 \\
0.03\end{array}$ & $\begin{array}{r}17.77 \\
3.80\end{array}$ & $\begin{array}{l}18.01 \\
8.47^{*}\end{array}$ & $\begin{array}{l}17.70 \\
8.57 *\end{array}$ & $\overline{-}$ & $\begin{array}{r}15.95 \\
3.58\end{array}$ & $\begin{array}{c}15.82 \\
9.14^{*}\end{array}$ & * $\begin{array}{r}15.28 \\
9.49 *\end{array}$ & $\overline{-}$ \\
\hline $\mathrm{FeO}$ & - & $10.86^{\circ}$ & - & $12.23^{\circ}$ & 0.03 & 4.53 & - & - & - & 5.28 & $9.14^{\circ}$ & - & Z \\
\hline $\mathrm{MnO}$ & 0.162 & 0.167 & 0.167 & 0.170 & 0.001 & 0.13 & 0.14 & 0.131 & 0.142 & 0.15 & 0.14 & 0.140 & 0.139 \\
\hline $\mathrm{MgO}$ & 6.15 & 6.39 & 7.21 & 7.31 & 0.07 & 8.17 & 8.08 & 7.78 & - & 9.59 & 9.87 & 9.44 & - \\
\hline $\mathrm{CaO}$ & 10.60 & 10.89 & 11.31 & 11.33 & 0.09 & 11.80 & 12.27 & 11.64 & - & 13.51 & 14.06 & 13.25 & - \\
\hline $\mathrm{Na}_{2} \mathrm{O}$ & 2.26 & 2.21 & 2.25 & 2.29 & 0.04 & 3.19 & 2.77 & 2.94 & - & 2.17 & 1.82 & 2.10 & - \\
\hline $\mathrm{K}_{2} \mathrm{O}$ & 0.63 & 0.63 & 0.51 & 0.54 & 0.01 & 0.07 & 0.08 & 0.075 & - & 0.05 & 0.06 & 0.045 & - \\
\hline $\mathrm{P}_{2}^{2} \mathrm{O}_{5}$ & 0.15 & 0.14 & 0.29 & 0.28 & 0.003 & 0.10 & 0.13 & 0.13 & - & 0.04 & 0.06 & 0.06 & - \\
\hline Sum & 99.85 & & 99.30 & & & $100.15 \dagger$ & $99.97 \dagger$ & 98.85 & & $100.60 \dagger$ & $100.22 \dagger$ & $\dagger 98.33$ & \\
\hline LOI & - & & - & & - & 3.16 & - & - & - & 3.21 & - & - & - \\
\hline \multicolumn{14}{|c|}{ Trace elements (ppm): } \\
\hline $\mathrm{Zn}$ & 87 & 80 & 111 & 105 & 5.5 & 64 & 57 & 70 & 65 & 69 & 62 & 70 & 64 \\
\hline $\mathrm{Ni}$ & 69 & 70 & 128 & 120 & 0.1 & 88 & 100 & 89 & 100 & 95 & 107 & 98 & 106 \\
\hline $\mathrm{Cr}$ & 97 & 92 & 298 & 300 & 1.1 & 313 & 264 & 326 & 301 & 254 & 213 & 314 & 317 \\
\hline $\mathrm{V}$ & 268 & 260 & 315 & 320 & 1.4 & 187 & 208 & 210 & 211 & 248 & 239 & 266 & 271 \\
\hline $\mathrm{Cu}$ & 111 & 105 & 138 & 140 & 0.9 & 56 & 65 & 74 & 73 & 108 & 110 & 108 & 104 \\
\hline $\mathrm{Zr}$ & 100 & 100 & 175 & 180 & 0.7 & 95 & 97 & 92 & 81 & 39.5 & 41 & 37 & 34 \\
\hline Sc & 36 & 36 & 31 & 31 & 0.3 & 31 & - & 34 & 35.9 & 30 & & 47.5 & 49 \\
\hline $\mathrm{Y}$ & 23 & 23 & 27 & 27 & 0.1 & 23.7 & 26 & 26 & 24.8 & 16.6 & 19 & 19 & 19 \\
\hline $\mathrm{Sr}$ & 204 & 190 & 398 & 420 & 1.6 & 156 & 156 & 168 & 181 & 136 & 137 & 136 & 143 \\
\hline $\mathrm{Ba}$ & 172 & 175 & 121 & 135 & 0.9 & 10 & 14 & 13 & 4 & 19 & 2 & 17.5 & 7 \\
\hline $\mathrm{Rb}$ & ND & ND & ND & ND & ND & 0.4 & 2 & - & 0.4 & 1 & 2 & - & 0.6 \\
\hline $\mathrm{Nb}$ & ND & ND & ND & ND & ND & 1.6 & - & - & 1.3 & 0.95 & - & - & 0.39 \\
\hline Cs & - & & - & & & - & - & - & 0.01 & - & - & - & 0.01 \\
\hline $\mathrm{U}$ & - & & - & & & - & - & - & 0.06 & - & - & - & 0.05 \\
\hline Th & - & & - & & & - & - & - & 0.07 & - & - & - & 0.05 \\
\hline $\mathrm{Pb}$ & - & & - & & & - & - & - & 0.5 & 0.94 & - & - & 0.65 \\
\hline Co & - & & - & & & 34 & 46 & - & 39.6 & 41 & 49 & - & 45.1 \\
\hline $\mathrm{Ta}$ & - & & - & & & - & - & - & 0.12 & - & - & - & 0.05 \\
\hline $\mathrm{Hf}$ & - & & - & & & - & - & - & 1.74 & - & - & - & 0.85 \\
\hline W & - & & - & & & - & - & - & 0.02 & - & - & - & 0.02 \\
\hline $\mathrm{Ga}$ & - & & - & & & - & - & - & 17 & - & - & - & 14 \\
\hline $\mathrm{Tl}$ & - & & - & & & - & - & - & 0.04 & - & - & - & 0.08 \\
\hline $\mathrm{La}$ & 11 & 10.5 & 15 & 17 & 0.3 & - & - & 4 & 3.14 & - & - & 2 & 1.31 \\
\hline $\mathrm{Ce}$ & - & & - & & & - & $=$ & - & 9.82 & - & - & - & 4.26 \\
\hline $\mathrm{Pr}$ & - & & - & & & - & - & - & 1.61 & - & - & - & 0.72 \\
\hline $\mathrm{Nd}$ & - & & - & & & - & - & - & 8.99 & - & - & - & 4.18 \\
\hline Sm & - & & - & & & - & - & - & 2.81 & - & - & - & 1.7 \\
\hline $\mathrm{Eu}$ & - & & - & & & - & - & - & 1.06 & - & - & - & 0.63 \\
\hline $\mathrm{Gd}$ & - & & - & & & - & - & - & 3.71 & - & - & - & 2.23 \\
\hline $\mathrm{Tb}$ & - & & - & & & - & - & - & 0.65 & - & - & - & 0.45 \\
\hline Dy & - & & - & & & - & - & - & 3.84 & - & - & - & 2.8 \\
\hline Ho & - & & - & & & - & - & - & 0.86 & - & - & - & 0.59 \\
\hline $\mathrm{Er}$ & - & & - & & & - & - & - & 2.57 & - & - & - & 1.85 \\
\hline $\mathrm{Tm}$ & - & & - & & & - & - & - & 0.37 & - & - & - & 0.27 \\
\hline $\mathrm{Yb}$ & - & & - & & & - & - & - & 2.1 & - & - & - & 1.66 \\
\hline Lu & - & & - & & & - & - & - & 0.43 & - & - & - & 0.37 \\
\hline
\end{tabular}

the lavas of the presently active arc (Table 3). The Site 841 intrusives bear the closest resemblance to lavas of the Lau Group, a sequence of 14- to 5.4-Ma basalts to dacites from the Lau Ridge remnant arc (Cole et al., 1985; Table 3). The least altered basalts have $\mathrm{Y} / \mathrm{Zr}$ and $\mathrm{Ba} / \mathrm{Zr}$ (the most diagnostic difference between arc units of different ages in the Tonga region) very close to those of the Lau Group lavas (Fig. 6). The $\mathrm{Ba} / \mathrm{La}$ ratios in the least altered samples range from 24 to 43; the Lau Group has Ba/La ratios of 10 to 37 , whereas the active Tofua Arc has Ba/La ratios of 36 to 160 (Cole et al., 1990). Unit 1 $\mathrm{Sr} / \mathrm{Nd}$ values are 21 to 30 , overlapping the range of the Lau Group ( 23 to 25 ), but they are much lower than lavas of the active arc ( 34 to 116; Cole et al., 1990). The La/Zr of Unit 1 lavas are like those of the Lau Group, although their $\mathrm{La}$ and $\mathrm{Zr}$ abundances are at the low end of the range for those lavas (Fig. 6). The Unit 1 basalts have $\mathrm{Sr}$ and $\mathrm{Nd}$ isotopic compositions within the range for lavas of the Korobasaga Group, a lava series that developed late in the evolution of the Lau Ridge (4.4-2.4 Ma) as the Lau Basin opened (Cole et al., 1985; Fig. 5). However, the Unit 1 lavas are not anywhere near as enriched in LILEs as the Korobasaga Group (Fig. 3 and Table 3).

The element abundances and ratios show a striking similarity between the Unit 1 basalt intrusives and the late Miocene Lau Group.
This similarity is consistent with the apparent age of the intrusives. If all of the dikes and sills are indeed part of a single intrusive event, that event must be late Miocene (foraminifer Zone N16 to Subzone 17a; 12-6 Ma; Parson, Hawkins, Allan, et al., 1992) or younger.

\section{Discussion}

The discovery of upper Miocene or younger sills and dikes in the outer forearc is surprising. Site 841 is now over $140 \mathrm{~km}$ from the presently active Tofua arc, and at least $75 \mathrm{~km}$ from what may have been the axis of late Miocene volcanism (near' 'Eua; Fig. 2). The outer parts of the forearc are generally assumed to be relatively cold, and far removed from arc volcanic activity since the late Eocene.

However, this is not the first report of such intrusives in forearc basin sediments. A diabase sill of basaltic andesite composition, intruded into mid-Miocene sediments, was cored at Site 793 in the Bonin forearc, $75 \mathrm{~km}$ east of the presently active arc (Shipboard Scientific Party, 1990b). The diabase has baked sediment along its margin, clearly showing that it was intruded into the sediments, and therefore is younger than mid-Miocene. A basalt interval was recovered within late Pliocene sediments at Site 781 in the Mariana forearc; 
Table 1 (continued).

\begin{tabular}{|c|c|c|c|c|c|c|c|c|c|c|c|c|}
\hline \multirow{3}{*}{$\begin{array}{l}\text { Sample: } \\
\text { Laboratory: } \\
\text { Method: }\end{array}$} & \multicolumn{4}{|c|}{ 135-835B-7R-2, 75-84 cm } & \multicolumn{4}{|c|}{$135-836 \mathrm{~A}-3 \mathrm{H}-3,33-43 \mathrm{~cm}$} & \multicolumn{4}{|c|}{$135-836 \mathrm{~A}-3 \mathrm{H}-4,88-100 \mathrm{~cm}$} \\
\hline & Queensland & d WHOI & $\mathrm{BU}$ & Durham & Queensland & WHOI & $\mathrm{I} B \mathrm{BU}$ & Durham & Queensland & WHOI & $\mathrm{BU}$ & Durham \\
\hline & XRF, AA & XRF & ICP & ICP-MS & XRF, AA & XRF & ICP & ICP-MS & XRF, AA & XRF & ICP & ICP-MS \\
\hline \multicolumn{13}{|c|}{ Major elements (wt\%): } \\
\hline $\mathrm{SiO}_{2}$ & 50.80 & 51.77 & 50.62 & - & 55.51 & 55.29 & 54.34 & - & 57.03 & 56.67 & 55.60 & - \\
\hline $\mathrm{TiO}_{2}^{2}$ & 1.04 & 0.85 & 0.86 & 0.89 & 1.35 & 1.34 & 1.32 & 1.35 & 1.21 & 1.19 & 1.16 & 1.21 \\
\hline $\mathrm{Al}_{2} \mathrm{O}_{3}$ & 15.52 & 16.37 & 16.20 & - & 14.95 & 14.84 & 14.60 & - & 14.70 & 14.63 & 14.40 & - \\
\hline $\mathrm{Fe}_{2} \mathrm{O}_{3}$ & 4.15 & $9.12 *$ & $9.26^{*}$ & - & 2.94 & $13.23^{*}$ & $13.14 *$ & - & 2.78 & $11.35^{*}$ & $12.46^{*}$ & - \\
\hline $\mathrm{FeO}$ & 5.75 & - & - & - & 9.45 & & & - & 8.93 & & - & - \\
\hline $\mathrm{MnO}$ & 0.13 & 0.13 & 0.121 & 0.125 & 0.20 & 0.21 & 0.20 & 0.20 & 0.26 & 0.26 & .249 & 0.254 \\
\hline $\mathrm{MgO}$ & 8.19 & 8.31 & 7.98 & - & 3.98 & 4.10 & 3.99 & - & 3.65 & 3.82 & 3.64 & - \\
\hline $\mathrm{CaO}$ & 11.43 & 12.86 & 12.71 & - & 8.45 & 8.63 & 8.42 & - & 8.12 & 8.33 & 7.96 & - \\
\hline $\mathrm{Na}_{2} \mathrm{O}$ & 2.59 & 2.03 & 2.20 & - & 3.39 & 2.89 & 3.00 & - & 3.26 & 3.01 & 3.11 & - \\
\hline $\mathrm{K}_{2} \mathrm{O}$ & 0.12 & 0.13 & 0.08 & $\overline{-}$ & 0.23 & 0.26 & 0.24 & $\bar{z}$ & 0.28 & 0.29 & 0.28 & - \\
\hline $\mathrm{P}_{2} \mathrm{O}_{5}$ & 0.07 & 0.08 & 0.10 & - & 0.13 & 0.14 & 0.16 & - & 0.13 & 0.15 & 0.17 & - \\
\hline Sum & $99.79 \div$ & $100.82 \dagger$ & 100.13 & & $100.58 \div$ & $99.73 \div$ & 99.42 & & $100.35+$ & $99.70 \div$ & 99.02 & \\
\hline LOI & 3.00 & - & - & - & 1.68 & - & - & - & 2.06 & - & - & - \\
\hline \multicolumn{13}{|c|}{ Trace elements (ppm): } \\
\hline $\mathrm{Zn}$ & & 76 & 106 & 93 & 113 & 97 & 82 & 122 & 112 & 96 & 114 & 107 \\
\hline $\mathrm{Ni}$ & 58 & 79 & 74 & 76 & 11 & 21 & $\begin{array}{l}02 \\
18\end{array}$ & 15 & 13 & 22 & 18 & 18 \\
\hline $\mathrm{Cr}$ & 108 & 121 & 204 & 193 & 10 & 10 & 8 & 4.9 & 4 & 8 & 7 & 4.2 \\
\hline $\mathrm{V}$ & 289 & 246 & 252 & 276 & 431 & 422 & $399^{\circ}$ & 412 & 389 & 367 & 354 & 377 \\
\hline $\mathrm{Cu}$ & 85 & 78 & 75 & 72 & 109 & 110 & 117 & 111 & 120 & 124 & 132 & 127 \\
\hline $\mathrm{Zr}$ & 48 & 43 & 38 & 33.8 & 72 & 73 & 68 & 73 & 76.9 & 77 & 72 & 74.7 \\
\hline $\mathrm{Sc}$ & 33 & - & 38 & 39.2 & 40 & - & $\begin{array}{l}100 \\
36\end{array}$ & 39.2 & 40 & - & 36 & 38.9 \\
\hline $\mathrm{Y}$ & 21.9 & 24 & 21 & 20.6 & 30 & 34 & 32 & 36 & 32.5 & 36 & 34 & 36.7 \\
\hline $\mathrm{Sr}$ & 123 & 131 & 128 & 132 & 136 & 147 & 150 & 156 & 134 & 147 & 148 & 154 \\
\hline $\mathrm{Ba}$ & 46 & 46 & 34 & 28.3 & 65 & 58 & 54 & 54 & 79 & 85 & 65 & 60.3 \\
\hline $\mathrm{Rb}$ & 1.9 & 3 & - & 1.9 & 2.7 & 6 & - & 4.1 & 4.4 & 7 & - & 4.1 \\
\hline $\mathrm{Nb}$ & 0.7 & - & - & 0.45 & 1.6 & - & - & 0.99 & 2.1 & - & - & 1.19 \\
\hline Cs & - & - & - & 0.01 & - & - & - & 0.14 & - & - & - & 0.12 \\
\hline $\mathrm{U}$ & $\overline{-}$ & $\bar{z}$ & Z & 0.13 & $=$ & 二 & 二 & 0.09 & $\bar{z}$ & $\bar{z}$ & $=$ & 0.13 \\
\hline Th & $\overline{-}$ & $=$ & $\bar{z}$ & 0.12 & $\overline{-}$ & 二 & 二 & 0.16 & $\bar{z}$ & $\bar{z}$ & $=$ & 0.23 \\
\hline $\mathrm{Pb}$ & 0.98 & - & - & 0.79 & - & - & - & $\begin{array}{l}1.10 \\
1.23\end{array}$ & 1.4 & - & - & 1.36 \\
\hline Co & 36 & 49 & - & 39.8 & 31 & 49 & - & 34.2 & 34 & 46 & - & 34.5 \\
\hline $\mathrm{Ta}$ & - & - & - & 0.04 & - & - & Z & 0.08 & - & - & - & 0.12 \\
\hline $\mathrm{Hf}$ & - & - & $\overline{-}$ & 1.02 & E & $=$ & - & 2.02 & $\overline{-}$ & $\overline{-}$ & - & 2.19 \\
\hline w & - & - & $\overline{-}$ & 0.06 & $\overline{-}$ & I & - & 0.03 & $\overline{-}$ & $\overline{-}$ & - & 0.10 \\
\hline $\mathrm{Ga}$ & - & - & - & 16 & - & - & - & 18 & - & - & - & 18 \\
\hline $\mathrm{Tl}$ & - & - & - & 0.04 & $\overline{-}$ & - & - & 0.10 & $=$ & $\overline{-}$ & - & 0.37 \\
\hline $\mathrm{La}$ & E & $\overline{-}$ & 1.5 & 1.57 & 二 & 二 & $2 . \overline{5}$ & 2.72 & Z & Z & 3 & 2.93 \\
\hline $\mathrm{Ce}$ & Z & $\equiv$ & - & 4.56 & $\overline{-}$ & $\bar{z}$ & - & 8.32 & $\overline{-}$ & $\overline{-}$ & - & 8.75 \\
\hline $\mathrm{Pr}$ & - & - & - & 0.75 & - & - & - & $\begin{array}{l}\text { l. } \\
1.36\end{array}$ & - & - & - & 1.47 \\
\hline $\mathrm{Nd}$ & - & - & - & 4.67 & - & - & - & 8.51 & - & - & - & 9.05 \\
\hline $\mathrm{Sm}$ & - & $=$ & - & 1.79 & $\overline{-}$ & $=$ & $=$ & $\begin{array}{l}3.09 \\
3.09\end{array}$ & $\overline{-}$ & $=$ & - & 3.42 \\
\hline Eu & - & $=$ & $\overline{-}$ & 0.77 & $\overline{-}$ & $=$ & $=$ & 1.11 & $\overline{-}$ & - & - & 1.18 \\
\hline Gd & - & $=$ & $\overline{-}$ & 2.7 & $\overline{-}$ & $=$ & $\bar{z}$ & 48.7 & $\bar{z}$ & $\bar{z}$ & $\overline{-}$ & 4.80 \\
\hline $\mathrm{Tb}$ & - & - & - & 0.53 & - & - & - & 0.85 & $\overline{-}$ & $\overline{-}$ & - & 0.88 \\
\hline Dy & - & - & - & 3.28 & $=$ & - & - & 5.4 & - & - & - & 5.67 \\
\hline Ho & $\overline{-}$ & $\bar{Z}$ & $\overline{-}$ & 0.76 & 二 & 二 & $\overline{-}$ & $\begin{array}{l}1.4 \\
1.24\end{array}$ & $\bar{z}$ & $\bar{z}$ & $\overline{-}$ & 1.23 \\
\hline Er & - & $=$ & $=$ & 2.14 & 二 & $\bar{z}$ & $\overline{-}$ & $\begin{array}{l}3.24 \\
3.77\end{array}$ & $\bar{Z}$ & 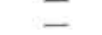 & $=$ & 4.00 \\
\hline $\mathrm{Tm}$ & - & - & $\overline{-}$ & 0.31 & - & - & $\overline{-}$ & 0.52 & $\bar{z}$ & $\overline{-}$ & - & 0.60 \\
\hline $\mathrm{Yb}$ & - & - & - & 1.91 & - & - & - & 3.36 & - & - & - & 3.60 \\
\hline Lu & $\overline{-}$ & $=$ & $\overline{-}$ & 0.39 & $\bar{z}$ & $\bar{z}$ & $=$ & 0.73 & $\overline{-}$ & $\overline{-}$ & - & 0.78 \\
\hline
\end{tabular}

no contacts were recovered, and the sample could be a sill or a flow (Shipboard Scientific Party, 1990a). Site 781 is about $100 \mathrm{~km}$ east of the Mariana active arc.

The recovery of mafic intrusions or flows within forearc basin sediments in three different forearcs indicates that magmatic activity may be far more common in forearcs than has been recognized. There are two possible explanations for the origin of these intrusives. First, they may represent melts generated in the mantle immediately beneath the forearc. This has been suggested for the Site 781 flow (Marlow et al., 1992). Alternatively, these mafic magmas may be injected into the forearc from the associated active arc along dikes or sills. Two arguments need to be examined in determining which explanation is the more likely. The first concerns the chemical composition of the intrusives, the second the physical constraints on dike injection and melt generation.

The Site 781 intrusives, which occur within late Miocene sediments, are strikingly similar to lavas that were erupting from the active arc in the late Miocene. The intrusives, in all regards, are typical island-arc lavas. The same is true of sills and flows from Sites 781 and 793 (Fig. 7). Each of the mafic units has element abundances and ratios typical of "main" arc eruptives and, in particular, are similar to lavas erupted from the arc active when the units were likely intruded (Miocene for Site 793; late Pliocene-Pleistocene for Site 781).

If the Lau Ridge is restored against the Tonga platform, where it would have been in the Miocene, it appears that the crest of the active arc had to be over $100 \mathrm{~km}$ from the trench. There are Miocene dikes on 'Eua, but no substantial Miocene volcanic section, which suggests that 'Eua was near the eastern side of the active arc province. Given that geometry, Site 841 must have occupied a position in the Miocene much like that in which it presently occurs. If it was less than $60 \mathrm{~km}$ from the trench the surface of the subducting slab was at most $40 \mathrm{~km}$ below the site (taking a slab geometry similar to that which now exists). If the Unit 1 intrusives were generated in the mantle, they had to be made at very shallow depths, presumably at unusually low temperatures, between the top of the slab and the base of the crust. This mantle might be expected to be extremely depleted because of older episodes of melt generation. Basaltic melts from that thin corner wedge should carry some distinctive chemical signatures: a greater silica saturation because of the low pressure of melting, very high volatile contents because of the high water concentrations needed to melt the cold mantle, signs of low degrees of melting because of the cool thermal regime, and very depleted incompatible element com- 
Table 1 (continued).

\begin{tabular}{|c|c|c|c|c|}
\hline \multirow{3}{*}{$\begin{array}{l}\text { Sample: } \\
\text { Laboratory: } \\
\text { Method: }\end{array}$} & \multicolumn{4}{|c|}{$135-834 \mathrm{~B}-13 \mathrm{R}-1,130-131 \mathrm{~cm}$} \\
\hline & Queensland & WHOI & $\mathrm{BU}$ & Durham \\
\hline & XRF, AA & XRF & ICP & ICP-MS \\
\hline \multicolumn{5}{|c|}{ Major elements (wt\%): } \\
\hline $\mathrm{SiO}_{2}$ & 49.97 & 50.12 & 48.92 & - \\
\hline $\mathrm{TiO}_{2}^{2}$ & 1.18 & 1.13 & 1.14 & 1.15 \\
\hline $\mathrm{Al}_{2} \mathrm{O}_{3}$ & 16.84 & 16.90 & 16,48 & - \\
\hline $\mathrm{Fe}_{2} \mathrm{O}_{3}$ & 3.79 & $8.88^{*}$ & $9.02 *$ & - \\
\hline $\mathrm{FeO}$ & 4.91 & - & - & - \\
\hline $\mathrm{MnO}$ & 0.15 & 0.14 & 0.133 & 0.136 \\
\hline $\mathrm{MgO}$ & 8.82 & 8.74 & 8.44 & - \\
\hline $\mathrm{CaO}$ & 11.55 & 12.00 & 11.32 & - \\
\hline $\mathrm{Na}_{2} \mathrm{O}$ & 2.89 & 2.66 & 2.80 & - \\
\hline $\mathrm{K}_{2} \mathrm{O}$ & 0.13 & 0.14 & 0.12 & - \\
\hline $\mathrm{P}_{2}^{2} \mathrm{O}_{5}$ & 0.10 & 0.12 & 0.12 & - \\
\hline Sum & $100.33 \dagger$ & $100.02 \dagger$ & 98.48, & \\
\hline LOI & 4.90 & - & - & - \\
\hline \multicolumn{5}{|c|}{ Trace elements (ppm): } \\
\hline $\mathrm{Zn}$ & 71 & 62 & 74 & 79 \\
\hline $\mathrm{Ni}$ & 95 & 106 & 90 & 93 \\
\hline $\mathrm{Cr}$ & 202 & 189 & 243 & 241 \\
\hline V & 210 & 225 & 237 & 252 \\
\hline $\mathrm{Cu}$ & 68 & 75 & 84 & 81 \\
\hline $\mathrm{Zr}$ & 81 & 86 & 78 & 73.7 \\
\hline $\mathrm{Sc}$ & 30 & - & 37 & 36.8 \\
\hline $\mathrm{Y}$ & 21.9 & 26 & 23 & 23.2 \\
\hline $\mathrm{Sr}$ & 164 & 161 & 175 & 178 \\
\hline $\mathrm{Ba}$ & 37 & 46 & 37 & 28.1 \\
\hline $\mathrm{Rb}$ & 1.2 & 2 & - & 1.1 \\
\hline $\mathrm{Nb}$ & 1.2 & - & - & 0.96 \\
\hline $\mathrm{Cs}$ & - & - & - & 0.03 \\
\hline $\mathrm{U}$ & - & - & - & 0.05 \\
\hline Th & - & - & - & 0.10 \\
\hline $\mathrm{Pb}$ & 1.81 & - & - & 1.31 \\
\hline Co & 35 & 48 & - & 39.1 \\
\hline $\mathrm{Ta}$ & - & - & - & 0.09 \\
\hline Hf & - & - & - & 1.7 \\
\hline W & - & - & - & 0.03 \\
\hline $\mathrm{Ga}$ & - & - & - & 16 \\
\hline $\mathrm{Tl}$ & - & - & - & 0.16 \\
\hline $\mathrm{La}$ & & & 3 & 2.63 \\
\hline $\mathrm{Ce}$ & - & - & - & 8.32 \\
\hline $\operatorname{Pr}$ & - & - & - & 1.26 \\
\hline $\mathrm{Nd}$ & - & - & - & 7.68 \\
\hline $\mathrm{Sm}$ & - & - & - & 2.67 \\
\hline $\mathrm{Eu}$ & - & - & - & 1.03 \\
\hline $\mathrm{Gd}$ & - & - & - & 3.45 \\
\hline $\mathrm{Tb}$ & - & - & - & 0.61 \\
\hline Dy & - & - & - & 3.71 \\
\hline Ho & - & - & - & 0.8 \\
\hline $\mathrm{Er}$ & - & - & - & 2.3 \\
\hline $\mathrm{Tm}$ & - & - & - & 0.35 \\
\hline $\mathrm{Yb}$ & - & - & - & 1.97 \\
\hline $\mathrm{Lu}$ & - & - & - & 0.42 \\
\hline
\end{tabular}

Notes: Values marked with an asterisk $(*)$ represent total iron as $\mathrm{Fe}_{2} \mathrm{O}_{3}$; a dash ( - ) indicates values that were not determined; a dagger $(\uparrow)$ represents major element analyses performed on a volatile-free basis. $\mathrm{BU}=$ Boston University, $\mathrm{WHOI}=$ Woods Hole Oceanographic Institution, ICP = inductively coupled plasma source spectrometry, ICP-MS = ICP mass spectrometry, $\mathrm{AA}=$ atomic absorption, and $\mathrm{XRF}=\mathrm{X}$-ray fluorescence. $\mathrm{ND}=$ no data.

positions because of the nature of the mantle. These are, in fact, all characteristic of the boninitic volcanic rocks that constitute an important phase of early arc volcanism in the Izu-Bonin-Marianas (Arculus et al., 1992) and that are generated at low pressures $(<6 \mathrm{~kb}$; van der Laan et al., 1989). Similar geometric arguments can be made for melting in the mantle beneath Sites 781 and 793 .

None of the forearc basin intrusives in the Tonga, Mariana, or Bonin forearcs have such a geochemical signature. They are all, in fact, exactly like the lavas erupted from their associated active arcs. An interesting contrast is provided by the sill at Site 793 in the Izu-Bonin forearc and the Oligocene basement there. The sill has $\mathrm{Ti} / \mathrm{Zr}=110, \mathrm{Ba} / \mathrm{Ce}=8$ and $\mathrm{K} / \mathrm{Ba}=61$, all values typical of the active arc. The Oligocene basement, however, has $\mathrm{Ti} / \mathrm{Zr}=63, \mathrm{Ba} / \mathrm{Ce}=4.6$, and $\mathrm{K} / \mathrm{Ba}=132$ to 600 . These values are characteristic of the depleted boninitic and tholeiitic lavas that form the Eocene forearc basement, rocks formed by shallow melting of a depleted, hydrous mantle wedge (Murton et al., 1992; Taylor et al., 1992). The Oligocene basement at Site 793, in fact, formed by rifting and magmatism within the forearc, so it is not surprising that basement has the same geochemical signature as the Eocene volcanics (Taylor, 1992). The sill within the Miocene sediments, however, has a chemical signature much more like the Miocene and recent active arc.

The chemical evidence, then, is most consistent with the derivation of the forearc basin dikes and sills in both the Tonga and Mariana-Bonin forearcs from the active arc. Do the physical constraints on melt generation and dike injection give the same answer? Melt generation in a depleted mantle wedge, even under water-saturated conditions, will require temperatures in excess of $1000^{\circ} \mathrm{C}$ (van der Laan et al., 1989). The sites of the Miocene and Pliocene or younger dike injections are 45 to $100 \mathrm{~km}$ from the trench. There was a well-established island arc to the west of the forearc when each of the dikes or flows was formed; the implication is that there existed a "normal," steady-state subduction zone. In such a case, temperatures at $50 \mathrm{~km}$ depth, $40-60 \mathrm{~km}$ behind the trench, $20 \mathrm{Ma}$ after the beginning of subduction, should be on the order of $500^{\circ} \mathrm{C}$ (Fryer and Fryer, 1985). This requires a substantial thermal anomaly to generate melts in situ in the corner of the mantle wedge. Ridge subduction could provide a mechanism for such an anomaly, but there is no other evidence suggesting the subduction of a ridge in any of the three forearcs during the appropriate time period.

If, on the other hand, the dikes and flows are derived from the associated active arc, they have been injected very large distances into the forearc. Site 841 was likely at least $70 \mathrm{~km}$, and perhaps over 100 $\mathrm{km}$, from the Miocene arc. Site 781 is $100 \mathrm{~km}$ from the active arc; Site 793 is $75 \mathrm{~km}$ from the active arc and probably occupied about the same position relative to the Miocene arc (Taylor, 1992). These are not unreasonable distance for large basaltic dikes and sills. The Palisades sill is $300 \mathrm{~m}$ thick and $80 \mathrm{~km}$ long, the Whin Sill in England $75 \mathrm{~m}$ thick and $125 \mathrm{~km}$ long, and Icelandic dikes are not uncommonly tens of meters wide and over $100 \mathrm{~km}$ long (Philpotts, 1990). The Higganum dike in New England runs nearly $250 \mathrm{~km}$ through the basement (Philpotts and Martello, 1986). The emplacement of dikes is likely to be facilitated by fracturing of the forearc. All of these intraoceanic forearcs are in extension (Mrozowski and Hayes, 1980; Hussong and Uyeda, 1982; Fryer and Fryer, 1985; Taylor, 1992). Both the Tonga and the Mariana forearcs are cut by both trench-parallel and trench-perpendicular faults and fractures (Fryer and Fryer, 1985; Herzer and Exon, 1985; Bloomer et al., 1988; MacLeod, this volume). These fractures would facilitate the intrusion of low-viscosity basaltic melts outward from the arc.

It is unlikely that the sills, dikes, and flows sampled have been emplaced all the way from the arc through the forearc basin sediments. Typical width/length ratios for shallow dikes emplaced by hydraulic fracture in consolidated sediments are $10^{-2}$ to $10^{-3}$ (Fedotov, 1978). The 18 - $\mathrm{m}$-thick dike sequence at Site 841 could only have traveled 18 $\mathrm{km}$ in such a case. Also, injection through wet sediments would have produced very high cooling rates and shorter propagation lengths. However, in the deeper crust and in higher density rocks, basaltic dikes typically have length-to-width ratios of $10^{-3}$ to $10^{-4}$, or for the same 18-m-thick unit distances of 18-180 km (Fedotov, 1978). The preexisting fractures in the forearc would only increase the distance such dikes could be injected.

We suggest that the dikes and sills found in Site 841 , and in similar positions in the Mariana-Bonin forearc, are derived from their associated active arc. They are fed by large dikes propagated through the forearc basement; the sampled intervals are intrusive bodies that have been fed from that deeper seated large dike. The intersection of multiple sets of faults, like those described on the Tonga platform (Herzer and Exon, 1985), could provide pathways for vertical movement of melt from a central feeder dike or sill. A very similar geometry has been described for en-echelon dike sets in New England, where 

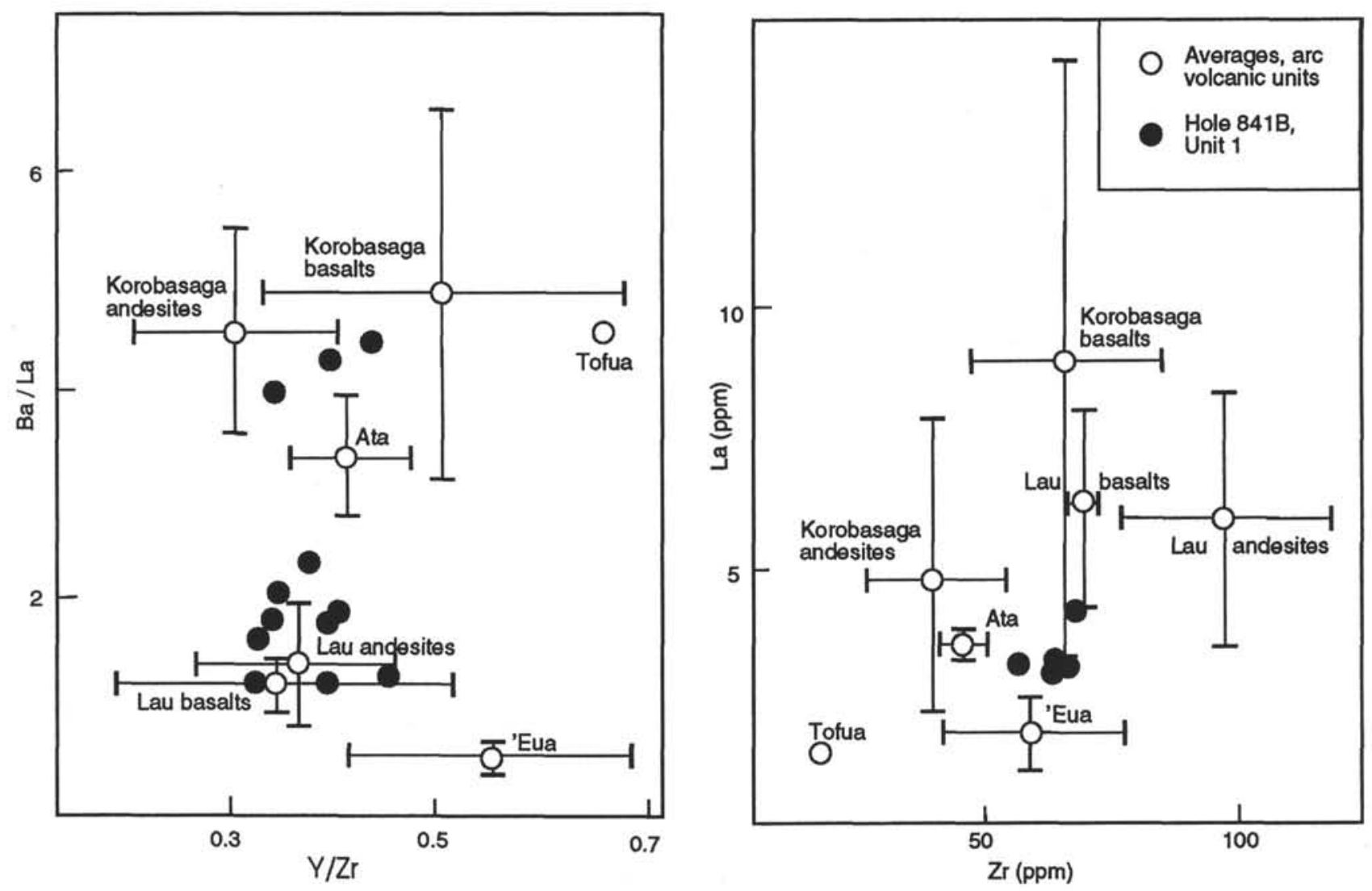

Figure 6. Comparison of Unit I basalts and other arc units in the Tonga region. The high-Ba Unit I samples are all noted as extensively veined. The reference fields are shown as averages (dots) and standard deviations (bars) for published analyses of the particular groups. Sources as in Figure 3. 'Eua volcanic rocks are Eocene in age, Lau Group basalts are Miocene, Korobasaga Group rocks are Pliocene, and rocks from 'Ata and the Tofua Arc are Pleistocene to Recent.

individual 4 to $10 \mathrm{~km}$ near-surface dikes are fed by the deeper and regionally extensive Higganum dike (Philpotts and Martello, 1986). This interpretation is mechanically reasonable and is more consistent with the chemistry of the intrusives than is an origin by in-situ melting of the mantle wedge beneath the forearc sites.

\section{PRE-LATE EOCENE SILICIC BASEMENT (UNITS 2-6) \\ Description}

At Site $841,209.55 \mathrm{~m}$ of volcanic basement ( 605.05 to $815.6 \mathrm{mbsf}$ ) were drilled; these rocks were divided into five units (Fig. 3). Unit 2, at the top of the rhyolitic basement, is $41.9 \mathrm{~m}$ of rhyolites and pumice breccias, which are divided into three subunits. Subunit $2 \mathrm{~A}$ is a $7.25-\mathrm{m}$ thick fault zone, developed within rhyolites, that separates the basement from the overlying calcareous sandstones. Subunit 2B (19.51 m thick) is a quartz-plagioclase phyric rhyolite flow or dome; it is the least altered unit within the basement complex (Figs. 8A-8B). The rhyolite averages $14 \%$ modal plagioclase $\left(\mathrm{An}_{48-40}\right), 7 \%$ quartz, $0.6 \%$ clinopyroxene (augite, $\mathrm{En}_{35} \mathrm{Wo}_{40} \mathrm{Fs}_{25}$ to $\mathrm{En}_{32} \mathrm{Wo}_{39} \mathrm{Fs}_{29}$ ), $0.6 \%$ orthopyroxene (hypersthene-ferrohypersthene $\mathrm{En}_{51} \mathrm{Wo}_{3} \mathrm{Fs}_{46}$ to $\mathrm{En}_{44} \mathrm{Wo}_{3} \mathrm{Fs}_{54}$ ), trace amounts of hornblende, and $0.5 \%$ opaques (magnetite and ilmenite), with $8 \%$ vesicles in a hydrated, perlitic groundmass. Representative analyses of the pyroxene and opaque phases are in Table 5. Locally within the unit, there are transitions to a poorly welded rhyolitic pumice. A similar poorly welded pumice breccia constitutes the 22.4-m-thick Subunit 2C.

Unit $3(25.6 \mathrm{~m})$ includes rhyolitic lapilli tuffs (Subunit 3A), welded rhyolitic lapilli tuffs (Subunit 3B), laminated crystal to lapilli tuffs
(Subunit 3C), and rhyolite breccias (Subunit 3D). Subunit 3B is bounded by clearly erosive contacts. The tuffs in Subunit $3 \mathrm{C}$ have convoluted and steeply dipping laminations that are cut by clastic dikes of sand to silt sized tuffaceous sediment. The tuffs coarsen in the lower $50 \mathrm{~cm}$ of the unit, and there is a concentration of large $(2.5$ $\mathrm{cm}$ ) lithic clasts at the base. The laminated unit could be a surge deposit or a reworked ash flow. Subunit 3D includes angular fragments of rhyolite, some of which are welded, with pumice and siltstone clasts. The rhyolites have $3 \%-5 \%$ quartz phenocrysts, $1 \%-$ $5 \%$ plagioclase, and $<1 \%$ magnetite in a granular matrix of quartz and feldspar. Symplectic plagioclase-quartz overgrowths on the phenocrysts are common in the rhyolite clasts.

Unit 4 is a 10.2-m-thick welded rhyolitic lapilli tuff with clasts of pumice, rhyolite, and basaltic andesite. The flattened pumice clasts are more concentrated toward the top of the unit, whereas the lithic clasts become more abundant, and larger, toward the base. The base of the unit is sheared and is gradational into Unit 5, an 18.8-m-thick sequence of sheared pumice breccias. Unit 6 , at the base of the hole, is at least $39 \mathrm{~m}$ thick. Recovery in the unit was less than $3 \%$ and it is difficult to characterize its lithology. Recovered fragments include welded tuffs, pumices, and mafic clasts. There are also mafic inclusions in some of the tuffs.

Alteration is pervasive throughout the basement cores, with the exception of the rhyolites in Subunit 2B. Illite, kaolinite, chlorite, pyrite, calcite, quartz and albite all are variously developed as replacements of the groundmass and as overgrowths and alterations of phenocrysts (see Schöps and Herzig, this volume). More detailed petrographic descriptions of each igneous unit are in Parson, Hawkins, Allan, et al. (1992). 
Table 2. Analyses of samples from Hole 841B Unit 1.

\begin{tabular}{|c|c|c|c|c|c|c|c|c|c|c|c|}
\hline Core: & $18 \mathrm{R}-1$ & $18 \mathrm{R}-2$ & $23 R-4$ & $23 \mathrm{R}-4$ & $25 R-1$ & $25 \mathrm{R}-4$ & $25 R-4$ & $25 \mathrm{R}-4$ & $26 \mathrm{R}-2$ & 26R-2 & 26R-2 \\
\hline Interval $(\mathrm{cm})$ : & $137-140$ & $28-32$ & $17-21$ & $8-12$ & $105-109$ & $21-22$ & $38-46$ & $42-46$ & $88-91$ & $81-86$ & $84-86$ \\
\hline Subunit: & IA & $1 \mathrm{~A}$ & 1B & IB & ID & ID & 1D & ID & $1 \mathrm{E}$ & $1 \mathrm{E}$ & $1 \mathrm{~F}$ \\
\hline Laboratory: & Durham & Ship & $\mathrm{BU}$ & Ship & Ship & Durham & $\mathrm{BU}$ & Queensland & Ship & BU & Ship \\
\hline \multicolumn{12}{|c|}{ Major elements (wt\%): } \\
\hline $\mathrm{SiO}_{2}$ & - & 54.13 & 50.66 & 52.59 & 52.59 & - & 49.66 & 50.25 & 52.58 & 51.03 & 51.85 \\
\hline $\mathrm{TiO}_{2}^{2}$ & - & 1.01 & 0.98 & 1.06 & 1.05 & - & 1.04 & 1.21 & 1.08 & 1.05 & 1.03 \\
\hline $\mathrm{Al}_{2} \mathrm{O}_{3}$ & - & 16.04 & 15.68 & 16.83 & 16.62 & - & 16.80 & 17.36 & 16.46 & 16.15 & 15.64 \\
\hline $\mathrm{Fe}_{2} \mathrm{O}_{3}^{*}$ & - & 12.53 & 11.96 & 13.06 & 13.13 & - & 12.51 & 13.43 & 13.08 & 12.78 & 12.42 \\
\hline $\mathrm{MnO}^{2}$ & - & 0.22 & 0.24 & 0.27 & 0.24 & - & 0.23 & 0.26 & 0.25 & 0.23 & 0.2 \\
\hline $\mathrm{MgO}$ & - & 4.55 & 4.54 & 4.76 & 4.8 & - & 4.64 & 4.98 & 4.93 & 4.80 & 4.36 \\
\hline $\mathrm{CaO}$ & - & 9.52 & 9.32 & 10.26 & 10.18 & - & 9.54 & 9.69 & 9.61 & 9.23 & 9.33 \\
\hline $\mathrm{Na}_{2} \mathrm{O}$ & - & 2.78 & 3.23 & 2.84 & 2.9 & - & 3.60 & 3.26 & 3.28 & 3.10 & 2.94 \\
\hline $\mathrm{K}_{2} \mathrm{O}$ & - & 0.16 & 0.15 & 0.2 & 0.09 & - & 0.17 & 0.17 & 0.45 & 0.92 & 0.26 \\
\hline $\mathrm{P}_{2} \mathrm{O}_{5}$ & - & 0.15 & 0.16 & 0.17 & 0.15 & - & 0.18 & 0.15 & 0.17 & 0.18 & 0.16 \\
\hline Total & & $101.09 \dagger$ & $96.93 * *$ & $102.04 \uparrow$ & $101.74 \dagger$ & & $98.36^{\text {*** }}$ & $100.76 t$ & $101.16 \div$ & $99.47 * *$ & $100.98 \dagger$ \\
\hline LOI & - & 1.29 & - & 1.01 & 0.72 & - & - & 3.39 & 1.55 & - & 0.87 \\
\hline \multicolumn{12}{|c|}{ Trace elements $(\mathrm{ppm})$ : } \\
\hline $\mathrm{Zn}$ & - & 123 & 148 & 173 & 132 & - & 128 & 186 & 166 & 146 & 90 \\
\hline $\mathrm{Ni}$ & - & 20 & 20 & 22 & 21 & - & 22 & 18 & 20 & 22 & 18 \\
\hline $\mathrm{Cr}$ & - & 14 & 26 & 17 & 12 & - & 28 & $26(24)$ & 17 & 27 & 12 \\
\hline V & - & 345 & 358 & 376 & 387 & - & 380 & 416 & 382 & 386 & 351 \\
\hline $\mathrm{Cu}$ & - & 122 & 114 & 114 & 128 & - & 133 & 115 & 117 & 140.5 & 132 \\
\hline $\mathrm{Zr}$ & 57 & 71 & 64 & 56 & 74 & 64.3 & 66 & 69 & 76 & 67 & 74 \\
\hline Sc & - & - & 39 & - & - & - & 40 & $43(38)$ & - & 40.5 & - \\
\hline $\mathrm{Y}$ & 25.6 & 23 & 25 & 24 & 24 & 26.1 & 26 & 23.5 & 25 & 26.5 & 25 \\
\hline $\mathrm{Sr}$ & 241 & 216 & 248 & 229 & 230 & 256 & 250 & 225 & 227 & 241 & 213 \\
\hline $\mathrm{Ba}$ & 76.1 & 90 & 79 & 256 & 125 & 123.6 & 124 & 145 & 310 & 294.5 & 140 \\
\hline $\mathrm{Rb}$ & 2.51 & 2 & - & 5 & 1 & 1.4 & - & 2 & 4 & - & 4 \\
\hline $\mathrm{Nb}$ & 0.63 & 1 & - & 1 & i & 0.67 & - & 0.77 & 1 & - & 2 \\
\hline Cs & 0.01 & - & - & - & - & BDL & - & 0.14 & - & - & - \\
\hline $\mathrm{U}$ & 0.16 & - & - & - & - & 0.18 & - & 0.18 & - & - & - \\
\hline Th & 0.25 & - & - & - & - & 0.25 & - & 0.15 & - & - & - \\
\hline $\mathrm{Pb}$ & 0.97 & - & - & - & - & 1.67 & - & 4.58 & - & - & - \\
\hline Co & - & - & - & - & - & - & - & 37 & - & - & - \\
\hline $\mathrm{Ta}$ & 0.04 & - & - & - & - & 0.12 & - & 0.06 & - & - & - \\
\hline $\mathrm{Hf}$ & 1.64 & - & - & - & - & 1.68 & - & 2.90 & - & - & - \\
\hline W & 0.06 & - & - & - & - & 0.07 & - & 0.09 & - & - & - \\
\hline $\mathrm{Tl}$ & - & - & - & - & - & - & - & 1.44 & - & - & - \\
\hline $\mathrm{Be}$ & - & - & - & - & - & - & - & 0.18 & - & - & - \\
\hline $\mathrm{La}$ & 3.13 & - & 3 & - & - & 3.24 & 3.1 & $4.17(3.4)$ & - & 3.4 & - \\
\hline $\mathrm{Ce}$ & 9.17 & - & - & - & - & 9.08 & - & $11.7(9.3)$ & - & - & - \\
\hline Pr & 1.47 & - & - & - & - & 1.54 & - & 2.05 & - & - & - \\
\hline $\mathrm{Nd}$ & 8.69 & - & - & - & - & 8.42 & - & $10.8(7.8)$ & - & - & - \\
\hline $\mathrm{Sm}$ & 2.81 & - & - & - & - & 2.84 & - & $3.46(2.6)$ & - & - & - \\
\hline $\mathrm{Eu}$ & 1.01 & - & - & - & - & 0.97 & - & $1.16(.99)$ & - & - & - \\
\hline $\mathrm{Gd}$ & 3.97 & - & - & - & - & 3.95 & - & $4.08(3.6)$ & - & - & - \\
\hline $\mathrm{Tb}$ & 0.67 & - & - & - & - & 0.64 & - & $0.72(0.6)$ & - & - & - \\
\hline Dy & 3.94 & - & - & - & - & 3.98 & - & 4.36 & - & - & - \\
\hline Ho & 0.87 & - & - & - & - & 0.91 & - & $0.93(0.8)$ & - & - & - \\
\hline $\mathrm{Er}$ & 2.58 & - & - & - & - & 2.69 & - & 2.63 & - & - & - \\
\hline $\mathrm{Tm}$ & 0.4 & - & - & - & - & 0.41 & - & 0.38 & - & - & - \\
\hline $\mathrm{Yb}$ & 2.4 & - & - & - & - & 2.48 & - & $2.52(2.6)$ & - & - & - \\
\hline $\mathrm{Lu}$ & 0.51 & - & - & - & - & 0.48 & - & $0.41(0.4)$ & - & - & - \\
\hline
\end{tabular}

Notes: Single asterisk $(*)$ represents total iron as $\mathrm{Fe}_{2} \mathrm{O}_{3}$; double asterisk $(* *)$ indicates that the sum does not include volatiles; dagger $\left(\frac{\hbar}{)}\right.$ indicates major elemen analyses performed on a volatile-free basis; dashes $(-)$ indicate values that were not determined. Values in parentheses were determined by instrumental neutron activation from Australian National University, B.W. Chappell, analyst; other analyses as in text. BDL = below detection level.

\section{Subaerial vs. Subaqueous Origin}

The environment of eruption of the Site 841 rhyolites has an important bearing on the tectonic history of the forearc. Clear evidence of welding exists in some of the tuffs (Fig. 8C), indicating a subaerial or very shallow submarine origin. No interbedded sediments are present in any of the units, and all of the units are completely devoid of microfossils. There is a very large volume of pumice within the section, which indicates eruption subaerially or in very shallow water, or which requires very high volatile contents. However, the phenocryst assemblage in the rhyolites is anhydrous, implying low concentrations of water or temperatures too high for the crystallization of biotite or amphibole. More important, many of the pumice breccias are poorly sorted; they include abundant low-density pumice clasts intimately mixed with higher density rhyolite and andesitic clasts. The pumice clasts would normally be separated from the lithic clasts by flotation in a submarine eruption. Only Unit 4 shows evidence of density sorting but is still poorly sorted.
The volcanic facies at Site 841 are similar to facies associated with subaerial eruptions in places like the Taupo volcanic zone (Ewart, 1968). Unit 2 is similar to late-stage ash flow deposits associated with plagioclase-quartz rhyolite domes (Ewart, 1968). Poorly consolidated ash-flow deposits (producing pumice breccias), ignimbrites, and plagioclase-quartz rhyolites are a common association throughout the Taupo zone (Ewart, 1968). We consider the textures of the volcanic units at Site 841 to be indicative of subaerial eruption. This is consistent with the interpretation that the environment of deposition for the calcareous sandstones above the rhyolites was in the photic zone (see Chaproniere, this volume). These sandstones contain fragments of rhyolitic debris like those found in the basement rocks.

\section{Geochemistry}

Most of the rocks recovered from Site 841 are tuffaceous or pumiceous and are extensively altered. The rhyolites of Subunit 2B, and rhyolite clasts within Subunits $3 \mathrm{C}-3 \mathrm{D}$ and Unit 4 , provide the 
Table 3. Average compositions of Site 841 Unit 1 lavas compared with compositions of arc lavas of different ages from the Tonga region.

\begin{tabular}{|c|c|c|c|c|c|c|c|}
\hline \multirow[t]{2}{*}{ Location: } & \multirow{2}{*}{$\begin{array}{c}\text { Hole 841B } \\
\text { Unit } 1\end{array}$} & \multirow[b]{2}{*}{ 'Eua } & \multicolumn{5}{|c|}{ Korobasaga } \\
\hline & & & 'Eua & Lau Group & Group & Tonga Arc & Ata \\
\hline Source: & $\begin{array}{l}\text { Table } 1 \\
\text { Average }\end{array}$ & $\begin{array}{l}\text { Cunningham } \\
\text { and } \\
\text { Anscombe } \\
\text { (1985) }\end{array}$ & $\begin{array}{c}\text { Hawkins and } \\
\text { Falvey } \\
(1985)\end{array}$ & $\begin{array}{c}\text { Cole et al. } \\
\text { (1985) }\end{array}$ & $\begin{array}{c}\text { Cole et al. } \\
\text { (1985) }\end{array}$ & $\begin{array}{c}\text { Ewart and } \\
\text { Hawkesworth } \\
\text { (1987) }\end{array}$ & $\begin{array}{c}\text { Vallier, } \\
\text { Stevenson, } \\
\text { And Scholl, } \\
\text { et al. (1985) }\end{array}$ \\
\hline \multicolumn{8}{|c|}{ Major elements (wt\%): } \\
\hline $\mathrm{SiO}_{2}$ & 51.52 & 53.95 & 54.87 & 55.16 & 55.76 & 53.21 & 52.28 \\
\hline $\mathrm{TiO}_{2}^{2}$ & 1.05 & 0.77 & 0.71 & 1.14 & 0.73 & 0.51 & 0.74 \\
\hline $\mathrm{Al}_{2} \mathrm{O}_{3}$ & 16.33 & 16.35 & 18.30 & 18.08 & 18.58 & 17.09 & 17.13 \\
\hline $\mathrm{Fe}_{2} \mathrm{O}_{3}^{*}$ & 12.72 & 9.66 & 10.32 & 9.37 & 7.44 & 10.92 & 10.98 \\
\hline $\mathrm{MnO}$ & 0.24 & 0.18 & 0.21 & 0.17 & 0.15 & 0.18 & 0.19 \\
\hline $\mathrm{MgO}$ & 4.67 & 4.52 & 5.36 & 3.62 & 4.41 & 5.37 & 5.48 \\
\hline $\mathrm{CaO}$ & 9.59 & 6.15 & 8.07 & 8.54 & 8.81 & 11.45 & 11.13 \\
\hline $\mathrm{Na}_{2} \mathrm{O}$ & 3.09 & 3.33 & 2.58 & 3.30 & 2.99 & 1.57 & 2.03 \\
\hline $\mathrm{K}_{2} \mathrm{O}$ & 0.28 & 0.40 & 0.20 & 0.84 & 1.24 & 0.34 & 0.52 \\
\hline $\mathrm{P}_{2} \mathrm{O}_{5}$ & 0.16 & 0.06 & 0.08 & 0.25 & 0.29 & 0.07 & 0.14 \\
\hline Sum & 99.65 & 95.37 & 100.70 & 100.47 & 100.40 & 100.71 & 100.62 \\
\hline \multicolumn{8}{|c|}{ Trace elements (ppm): } \\
\hline $\mathrm{Zn}$ & 144 & 75 & - & 90 & 80 & 84 & 57 \\
\hline $\mathrm{Ni}$ & 20 & 8 & 49 & 14 & 16 & 23 & 86 \\
\hline $\mathrm{Cr}$ & 20 & 31 & - & 28 & 27 & 52 & 51 \\
\hline $\mathrm{V}$ & 376 & 280 & 181 & 243 & 179 & 305 & 482 \\
\hline $\mathrm{Cu}$ & 124 & 22 & - & 45 & 47 & - & - \\
\hline $\mathrm{Zr}$ & 67 & - & 42 & 97 & 66 & 18 & 46 \\
\hline $\mathrm{Sc}$ & 40 & 40 & - & 30 & 21 & - & - \\
\hline $\mathrm{Y}$ & 25 & 21 & 26 & 35 & 20 & 12 & 19 \\
\hline $\mathrm{Sr}$ & 234 & 140 & 115 & 331 & 533 & 196 & 251 \\
\hline $\mathrm{Ba}$ & 157 & 72 & 37 & 138 & 309 & 88 & 159 \\
\hline $\mathrm{Rb}$ & 2.74 & - & 1 & 11.2 & 37 & 4.4 & 11 \\
\hline $\mathrm{Nb}$ & 1 & - & - & 2 & 2 & 0.56 & - \\
\hline $\mathrm{Pb}$ & 2.41 & - & - & 2 & 4.3 & 1.8 & 9 \\
\hline $\mathrm{La}$ & 3.49 & 1.24 & - & 6 & 9 & 1.5 & 3.5 \\
\hline $\mathrm{Ce}$ & 9.81 & - & - & 19 & 20 & 3.7 & 8.9 \\
\hline \multicolumn{8}{|l|}{ Ratios: } \\
\hline $\mathrm{Ba} / \mathrm{Zr}$ & 2.3 & - & 0.9 & 1.4 & 4.7 & 4.9 & 3.5 \\
\hline $\mathrm{Ti} / \mathrm{Zr}$ & 94 & - & 101 & 70 & 66 & 170 & 96 \\
\hline $\mathrm{Y} / \mathrm{Zr}$ & 0.37 & - & 0.62 & 0.36 & 0.30 & 0.67 & 0.41 \\
\hline $\mathrm{Ba} / \mathrm{La}$ & 45 & 58 & - & 23 & 34 & 59 & 45 \\
\hline
\end{tabular}

Notes: Dashes (-) indicate values that were not determined; single asterisk (*) indicates total iron as $\mathrm{Fe}_{2} \mathrm{O}_{3}$.

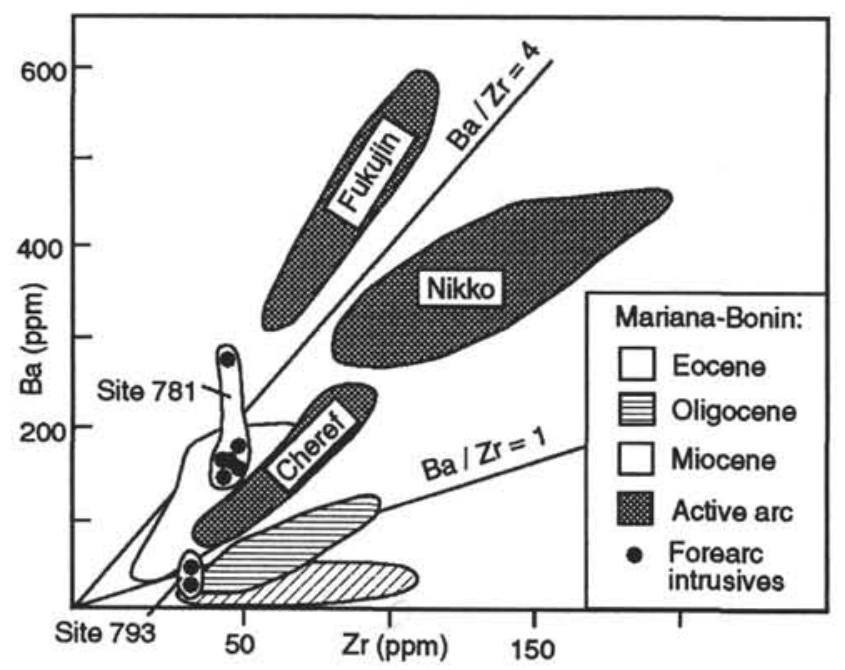

Figure 7. Compositions of forearc basin dikes and sills from Site 781 (in Pliocene-Pleistocene sediments; Shipboard Scientific party, 1990a) and Site 793 (in Miocene sediments; Shipboard Scientific Party, 1990b) compared with arc volcanic units of different ages in the Mariana system. Eocene analyses for forearc lavas from Bloomer (1987) and Reagan and Meijer (1984); Oligocene analyses from Reagan and Meijer (1984) and Wood et al. (1980); Miocene analyses from Wood et al. (1980); active arc analyses for selected volcanoes from Bloomer et al. (1989).
Table 4. Isotopic analyses of volcanic rocks from Hole 841B.

\begin{tabular}{|c|c|c|c|c|}
\hline Core, section: & $\begin{array}{r}18 \mathrm{R}-1 \\
137-140\end{array}$ & $\begin{array}{l}25 \mathrm{R}-3 \\
0\end{array}$ & $25 R-4$ & $\begin{array}{l}50 \mathrm{R}-1 \\
16-18\end{array}$ \\
\hline $\begin{array}{l}\text { Interval }(\mathrm{cm}) \text { : } \\
\text { Subunit: }\end{array}$ & $\begin{array}{c}137-140 \\
1 \mathrm{~A}\end{array}$ & $\begin{array}{c}118-119 \\
\text { ID }\end{array}$ & $\begin{array}{c}21-22 \\
1 D\end{array}$ & $\begin{array}{c}16-18 \\
2 B\end{array}$ \\
\hline${ }^{206} \mathrm{~Pb} /{ }^{204} \mathrm{~Pb}$ & 18.707 & 18.716 & 18.709 & 18.750 \\
\hline${ }^{207} \mathrm{~Pb} / 204 \mathrm{~Pb}$ & 15.536 & 15.537 & 15.547 & 15.539 \\
\hline${ }^{208} \mathrm{~Pb} /{ }^{204} \mathrm{~Pb}$ & 38.296 & 38.324 & 38.310 & 38.341 \\
\hline${ }^{87} \mathrm{Sr} /{ }^{\beta 6} \mathrm{Sr}$ & 0.703380 & & 0.703466 & \\
\hline${ }^{143} \mathrm{Nd} /{ }^{144} \mathrm{Nd}$ & 0.513096 & 0.513085 & 0.513085 & 0.513116 \\
\hline
\end{tabular}

Note: Analytical methods detailed in Hergt and Nilsson (this volume).

only materials suitable for analysis. All of the analyzed samples are high-silica, low-K rhyolites (Table 6). The freshest samples, the perlitic glasses in Subunit 2B, average $77.6 \% \mathrm{SiO}_{2}$ and $5.6 \%$ total alkalis (Table 6), making them rhyolites sensu strictu, by the criteria of Le Bas et al. (1986). We will refer to these rocks as low-K rhyolites, to emphasize their low $\mathrm{K}_{2} \mathrm{O} / \mathrm{Na}_{2} \mathrm{O}(0.12-0.4$; Ewart, 1979). Some of the rhyolitic clasts show very high $\mathrm{SiO}_{2}$ ( $>80 \%$; Table 6); this results from secondary silica developed in post-crystallization graphic intergrowths with feldspar (Shipboard Scientific Party, 1992). All of the rhyolites have low contents of $\mathrm{Zr}, \mathrm{Y}, \mathrm{Ba}$, and REEs, considering their high $\mathrm{SiO}_{2}$ concentrations. All of the analyzed rocks have similar 
A $\mathrm{cm}$

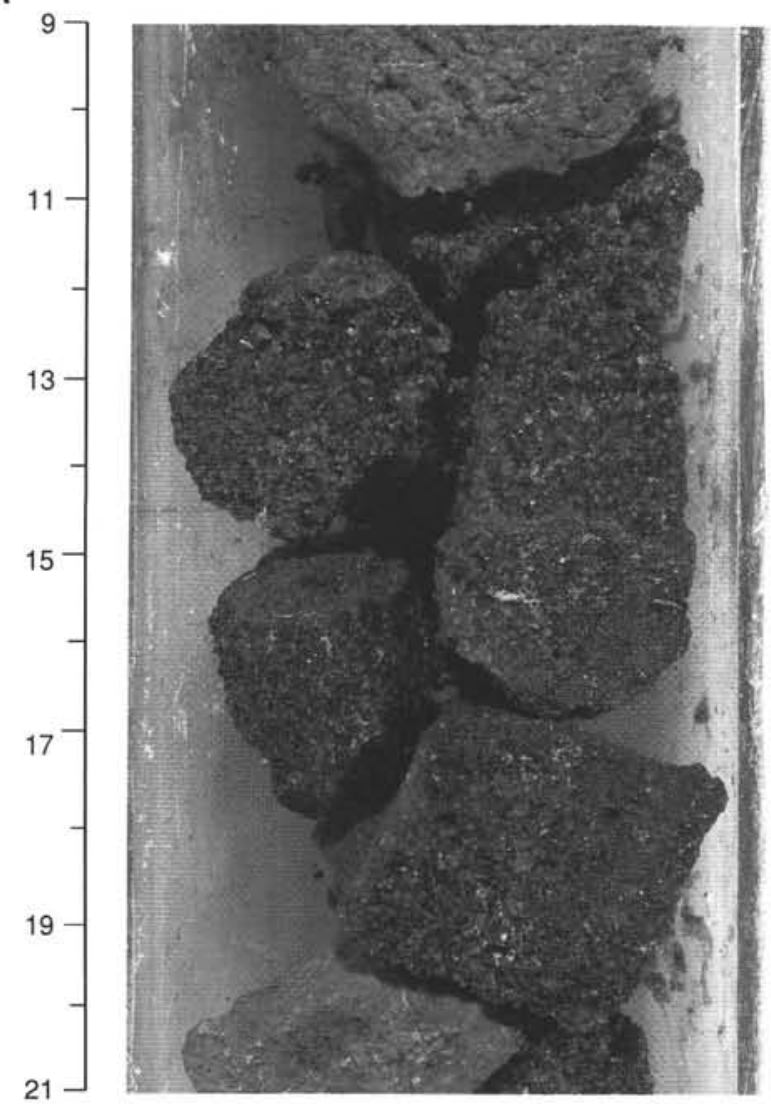

C ${ }_{24}$
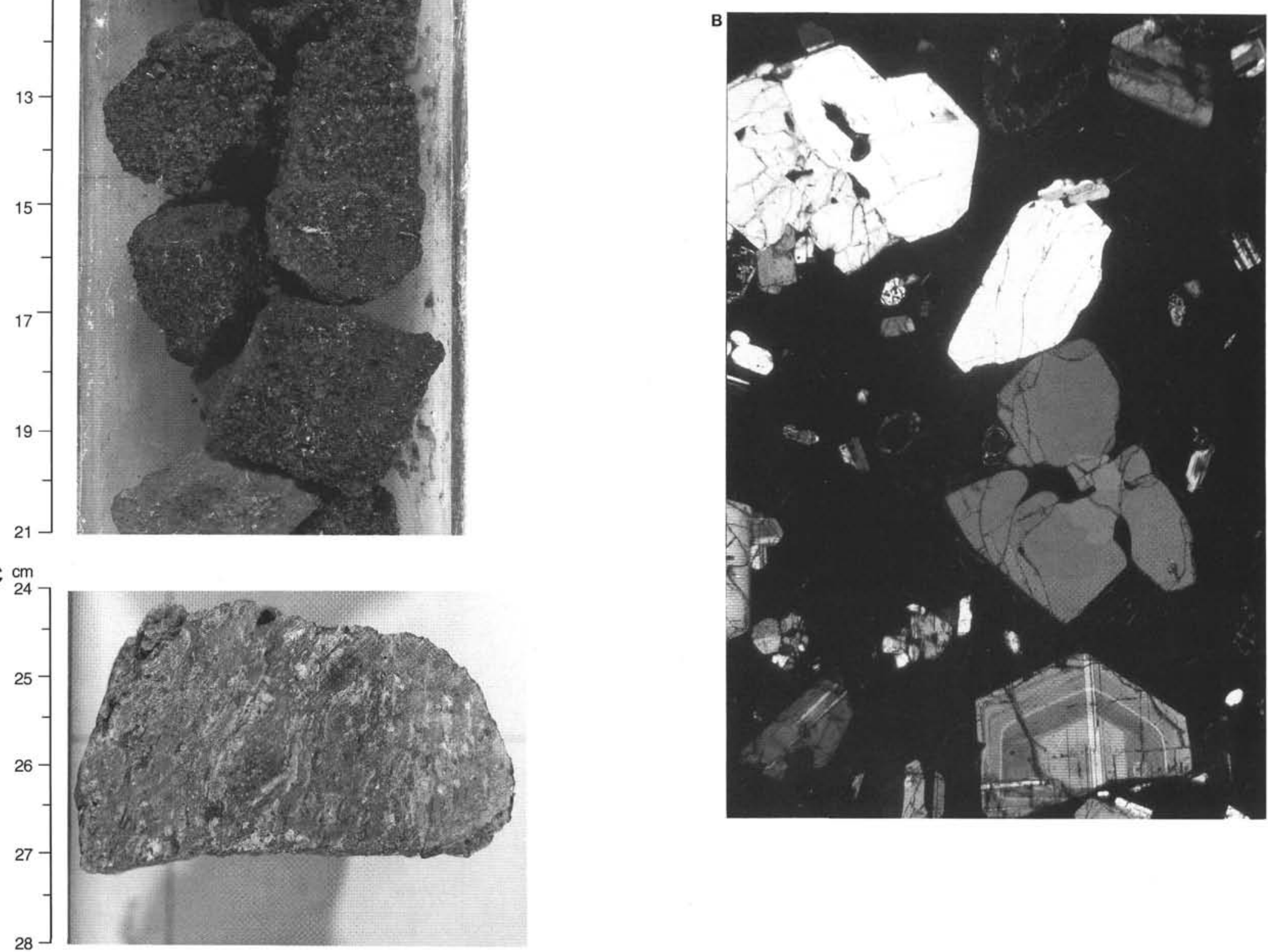

Figure 8. A. Plagioclase-quartz phyric rhyolite pitchstone from Subunit 2B (Interval I35-84IB-49R-1, 9-2I cm). B. Photomicrograph of Subunit 2B rhyolite; field of view is $6 \mathrm{~mm}$ from top to bottom (Sample 135-84IB-50R-1, 14-17 cm). C. Welded tuff from Unit 6 (Sample 135-84I B-66R-CC, 24-28 cm). 
Table 5. Representative analyses of phenocryst phases in Hole 841B Subunit 2B.

\begin{tabular}{|c|c|c|c|c|c|}
\hline & Magnetite & $\begin{array}{l}\text { Low-Mg } \\
\text { ilmenite }\end{array}$ & $\begin{array}{l}\text { High- } \mathrm{Mg} g \\
\text { ilmenite }\end{array}$ & $\begin{array}{l}\text { Average } \\
\text { clinopyroxene } \\
(N=10)\end{array}$ & $\begin{array}{c}\text { Average } \\
\text { orthopyroxene } \\
(N=9)\end{array}$ \\
\hline & 0.14 & BDL & 0.02 & 51.77 & 51.21 \\
\hline $\mathrm{TiO}_{2}^{-}$ & 14.05 & 47.22 & 48.02 & 0.21 & 0.13 \\
\hline $\mathrm{Al}_{2} \mathrm{O}_{3}$ & 2.11 & 0.14 & 0.17 & 0.76 & 0.36 \\
\hline $\mathrm{FeO}{ }^{3}$ & 76.57 & 49.56 & 48.11 & 15.38 & 30.71 \\
\hline $\mathrm{MnO}$ & 0.65 & 0.80 & 0.63 & 0.68 & 1.22 \\
\hline $\mathrm{MgO}$ & 0.81 & 1.47 & 2.86 & 11.44 & 15.77 \\
\hline $\mathrm{CaO}$ & 0.09 & 0.09 & 0.03 & 18.97 & 1.33 \\
\hline $\mathrm{Na}_{2} \mathrm{O}$ & BDL & BDL & $\mathrm{BDL}$ & 0.25 & 0.05 \\
\hline $\mathrm{ZnO}$ & 0.29 & $\mathrm{BDL}$ & $\mathrm{BDL}$ & BDL & BDL \\
\hline Sum & 94.71 & 99,28 & 99.82 & 99.46 & 100.78 \\
\hline $\mathrm{Fe}_{2} \mathrm{O}_{3}$ & 38.49 & 11.83 & 11.82 & $-\overline{0}$ & 0.71 \\
\hline $\mathrm{FeO}$ & 41.94 & 38.92 & 37.48 & 15.38 & 30.07 \\
\hline Sum & 98.57 & 100.47 & 101.01 & 99.46 & 100.85 \\
\hline $\begin{array}{l}\mathrm{T}\left({ }^{\circ} \mathrm{C}\right) \\
\log \mathrm{f}_{\mathrm{O} 2}\end{array}$ & & $\begin{array}{l}906 \\
-11.87\end{array}$ & $\begin{array}{l}907 \\
-11.85\end{array}$ & & \\
\hline
\end{tabular}

Note: Data determined on Section 135-841B-50R-1,5-9 cm. Single asterisk (*) indicates total iron as $\mathrm{FeO} . \mathrm{Fe}_{2} \mathrm{O}_{3}$ and $\mathrm{FeO}$ partitioning based on Stormer (1983). Temperatures and oxygen fugacities from Buddington and Lindsley (1964) and Ghiorso and Carmichael (1981). Analyses by electron microprobe at the University of Queensland. $\mathrm{BDL}=$ below detection limit. chemical compositions, indicating that the units at Site 841 are part of a single magma series. However, the rhyolites of Subunit $2 \mathrm{~B}$ are the freshest samples and the only ones that are clearly part of a flow or dome. The subsequent discussion of the chemistry of the basement units will refer to the average composition of the Subunit $2 \mathrm{~B}$ rhyolites (Table 7).

The two hypotheses advanced for the origin of the basement at Site 841 (Parson, Hawkins, Allan, et al., 1992) were that it was part of an Eocene sequence correlative to rocks on 'Eua, or that it was a fragment derived from rifted Cretaceous crust, like that exposed on the Lord Howe Rise, that was dispersed by the original breakup of the Southwest Pacific (Burns and Andrews, 1973). Analyses of Lord Howe Rise basement samples from DSDP Leg 21, Site 207 (Table 6) show that they are high- $\mathrm{K}_{2} \mathrm{O}$ rhyolites similar to other continental rift rhyolitic sequences (Fig. 9). Although they have $\mathrm{Nb}, \mathrm{Ta}$, and $\mathrm{Ti}$ depletions like the Site 841 rocks, the Lord Howe Rise rhyolites are highly enriched in incompatible elements (Fig. 10) and have pronounced LREE enrichments (Fig. 11). The Site 841 rhyolites clearly are not materials derived from a crustal fragment similar to the Cretaceous rhyolites of the Lord Howe Rise.

The other hypothesis is that the Site 841 rhyolites are part of an Eocene complex developed during the earliest subduction of the Pacific Plate beneath the Indo-Australian Plate. The rhyolites have a

Table 6. Analyses of rhyolitic volcanic rocks from Hole 841B Units 2-6.

\begin{tabular}{|c|c|c|c|c|c|c|c|c|c|c|c|c|c|}
\hline Hole: & $841 \mathrm{~B}$ & $841 B$ & $841 \mathrm{~B}$ & $841 \mathrm{~B}$ & $841 \mathrm{~B}$ & $841 \mathrm{~B}$ & $841 \mathrm{~B}$ & $841 \mathrm{~B}$ & $841 \mathrm{~B}$ & $207 \mathrm{~A}$ & $207 \mathrm{~A}$ & $207 \mathrm{~A}$ & $207 \mathrm{~A}$ \\
\hline Core, section: & $49 \mathrm{R}-1$ & $47 \mathrm{R}-2$ & $50 R-1$ & 50R-1 & $54 \mathrm{R}-2$ & 56R-CC & $57 \mathrm{R}-1$ & $59 \mathrm{R}-2$ & $62 \mathrm{R}-\mathrm{CC}$ & $34 \mathrm{R}-2$ & $35 \mathrm{R}-3$ & $40 \mathrm{R}-1$ & $42 \mathrm{R}-2$ \\
\hline Interval $(\mathrm{cm})$; & $10-13$ & $147-149$ & $5-9$ & $16-18$ & $142-146$ & $2-3$ & $10-13$ & $14-18$ & $11-15$ & $110-113$ & $108-111$ & $98-101$ & $43-46$ \\
\hline Subunit: & $2 \mathrm{~B}$ & 2B & $2 \mathrm{~B}$ & 2B & $3 \mathrm{C}$ & 3D & 3D & 3D & 4 & Lord Howe Rise & Lord Howe Rise & Lord Howe Rise & Lord Howe Rise \\
\hline Laboratory: & Ship & $\mathrm{BU}$ & Queensland & Durham & WHOI & Ship & $\mathrm{BU}$ & BU & Ship & Queensland & Queensland & Queensland & Queensland \\
\hline \multicolumn{14}{|c|}{ Major elements (wt\%): } \\
\hline $\mathrm{SiO}_{2}$ & 78.46 & 75.64 & 74.52 & 78.63 & 76.31 & 80.5 & 80.84 & 77.25 & 75.94 & 75.97 & 76.89 & 77.50 & 75.77 \\
\hline $\mathrm{TiO}_{2}^{2}$ & 0.25 & 0.24 & 0.37 & 0.16 & 0.34 & 0.28 & 0.24 & 0.26 & 0.23 & 0.18 & 0.20 & 0.17 & 0.26 \\
\hline $\mathrm{Al}_{2} \mathrm{O}_{3}$ & 12.35 & 11.46 & 12.87 & 12.31 & 12.43 & 11.56 & 11.44 & 11.79 & 10.83 & 13.52 & 12.89 & 12.58 & 13.15 \\
\hline $\mathrm{Fe}_{2} \mathrm{O}_{3}^{\circ}$ & 2.37 & 2.15 & 3.29 & 2.06 & 3.72 & 2.48 & 0.92 & 2.21 & 4.35 & 2.38 & 2.01 & 1.87 & 2.58 \\
\hline $\mathrm{MnO}$ & 0.07 & 0.06 & 0.07 & 0.09 & 0.03 & 0.02 & 0.01 & 0.01 & 0.06 & 0.012 & 0.014 & 0.024 & 0.04 \\
\hline $\mathrm{MgO}$ & 0.25 & 0.33 & 0.85 & 0.21 & 1.81 & 0.95 & 1.08 & 0.51 & 0.74 & 0.79 & 0.27 & 0.34 & 0.16 \\
\hline $\mathrm{CaO}$ & 1.83 & 1.71 & 2.93 & 1.59 & 1.32 & 1.80 & 1.43 & 1.65 & 4.97 & 0.30 & 0.46 & 0.55 & 1.09 \\
\hline $\mathrm{Na}_{2} \mathrm{O}$ & 4.52 & 4.55 & 4.03 & 4.31 & 3.85 & 3.00 & 3.25 & 3.45 & 3.18 & 2.75 & 3.23 & 2.98 & 3.14 \\
\hline $\mathrm{K}_{2} \mathrm{O}$ & 1.46 & 1.24 & 1.23 & 0.82 & 0.68 & 0.38 & 0.22 & 0.67 & 1.39 & 4.09 & 4.43 & 4.30 & 4.14 \\
\hline $\mathrm{P}_{2} \mathrm{O}_{5}$ & 0.05 & 0.04 & 0.04 & 0 & 0.06 & 0.04 & 0.05 & 0.00 & 0.06 & 0.02 & 0.03 & 0.02 & 0.03 \\
\hline Sum & $101.61 \dagger$ & $97.42^{* *}$ & $100.20 t$ & $100.00+$ & 100.194 & 101.014 & $99.45 * *$ & $97.79 * *$ & $101.75 t$ & $100.01 \dagger$ & $100.42 \dagger$ & $100.33 \%$ & $100.36 t$ \\
\hline LOI & 5.42 & - & 4.66 & - & - & 2.59 & - & - & 5.17 & 9.08 & 5.24 & 9.18 & 5.34 \\
\hline \multicolumn{14}{|c|}{ Trace elements (ppm): } \\
\hline $\mathrm{Zn}$ & 35 & 43 & 57 & - & - & 44 & 20 & 33 & 0 & 131 & 165 & 128 & 174 \\
\hline $\mathrm{Ni}$ & 2 & $<$ & 1 & - & 7 & 4 & 7 & 14 & i & - & - & - & - \\
\hline $\mathrm{Cr}$ & 0 & 5 & $19(15)$ & - & 7 & 0 & & & 0 & 2 & 4 & 5 & 5 \\
\hline $\mathrm{V}$ & 3 & $<5$ & 34 & - & 33 & 15 & & & 9 & 2 & - & 3 & 3 \\
\hline $\mathrm{Cu}$ & 10 & 21 & 1 & - & 25 & 9 & & 22 & 21 & - & - & & - \\
\hline $\mathrm{Zr}$ & 175 & 182 & 134 & 161 & 148 & 184 & 143 & 145 & 137 & 334 & 368 & 296 & 492 \\
\hline $\mathrm{Sc}$ & 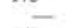 & 11 & $16(13)$ & - & - & - & 10 & 9 & - & 1 & 2 & 2 & 6 \\
\hline $\mathrm{Y}$ & 62 & 61 & 44 & 60 & 53 & 64 & 53 & 44 & 50 & 52 & 76 & 55 & 60 \\
\hline $\mathrm{Sr}$ & 49 & 50 & 63 & 70 & 72 & 76 & 47 & 61 & 137 & 32 & 63 & 33 & 145 \\
\hline $\mathrm{Ba}$ & 198 & 190 & 191 & 179 & 342 & 116 & 86 & 104 & 89 & 193 & 547 & 152 & 1260 \\
\hline $\mathrm{Rb}$ & 14 & - & 10.4 & ii & 7 & 8 & - & - & 4 & 198 & 188 & 206 & 174 \\
\hline $\mathrm{Nb}$ & 2 & - & 1.13 & 1.2 & - & 2 & - & $=$ & 2 & 30.4 & 37.5 & 28 & 30.2 \\
\hline $\mathrm{Cs}$ & - & - & $0.25(0.40)$ & ) 0.37 & - & - & - & - & - & 10.7 & 10.2 & 11.3 & 10.3 \\
\hline U & - & - & 0.28 & 0.25 & - & - & - & - & - & 3.65 & 3.96 & 3.66 & 3.68 \\
\hline Th & - & - & 0.39 & 0.42 & - & - & - & $=$ & - & 16.1 & 14.5 & 14.5 & 13.3 \\
\hline $\mathrm{Pb}$ & - & - & 3.06 & 4.94 & - & - & - & - & - & 25 & 27.9 & 20.4 & 42.0 \\
\hline Co & - & - & 5 & & 13 & - & - & - & - & 3 & 2 & - & - \\
\hline $\mathrm{Ta}$ & - & - & 0.08 & 0.12 & - & - & - & - & - & 1.96 & 1.81 & 1.76 & 1.63 \\
\hline $\mathrm{Hf}$ & - & - & 4.34 & 4.76 & - & - & - & - & - & 8.3 & 6.63 & 7.45 & 8.85 \\
\hline w & - & - & 0.08 & 0.14 & - & - & - & - & - & 1.64 & 1.79 & 1.74 & 1.69 \\
\hline $\mathrm{TI}$ & - & - & 0.79 & & - & - & - & - & - & 9.92 & 10.7 & 17.8 & 12.4 \\
\hline $\mathrm{Be}$ & - & - & 0.25 & & - & - & $=$ & $=$ & - & 5.1 & 5.3 & 5.2 & 6.5 \\
\hline $\mathrm{La}$ & - & 5 & $4.33(3.5)$ & 4.23 & - & - & 4 & 5 & - & 47.6 & 75 & 55.3 & 59.5 \\
\hline $\mathrm{Ce}$ & 20 & - & $13.7(11.2)$ & 12.95 & - & 19 & - & - & 20 & 101 & 142 & 115 & 124 \\
\hline Pr & - & - & 2.57 & 2.15 & - & - & - & - & - & 12.3 & 19.6 & 14.2 & 15.2 \\
\hline $\mathrm{Nd}$ & - & - & 13.9 (11) & 12.61 & - & - & - & $=$ & - & 44.9 & 70.3 & 51.9 & 55.3 \\
\hline $\mathrm{Sm}$ & - & - & $4.92(3.6)$ & 4.96 & - & - & - & - & - & 10.2 & 15.4 & 11.6 & 12.4 \\
\hline $\mathrm{Eu}$ & - & - & $1.15(0.96)$ & 1.12 & - & - & - & - & - & 0.48 & 1.39 & 0.54 & 2.23 \\
\hline Gd & - & - & $6.42(5.5)$ & 7.5 & $=$ & $\overline{-}$ & $=$ & $=$ & $=$ & 10.3 & 14.8 & 11.6 & 12.2 \\
\hline $\mathrm{Tb}$ & - & - & $1.24(0.8)$ & 1.12 & - & - & - & - & - & 1.57 & 2.22 & 1.75 & 1.81 \\
\hline Dy & - & - & 7.90 & 9.01 & - & - & - & - & - & 9.0 & 12.5 & 9.79 & 10.0 \\
\hline Ho & - & - & $1.75(1.6)$ & 1.98 & - & - & - & - & - & 1.84 & 2.54 & 1.97 & 2.04 \\
\hline $\mathrm{Er}$ & - & - & 5.20 & 5.85 & - & - & - & $=$ & $=$ & 5.02 & 6.98 & 5.32 & 5.53 \\
\hline $\mathrm{Tm}$ & - & - & 0.80 & 1.01 & - & - & - & - & - & 0.75 & 1.05 & 0.80 & 0.82 \\
\hline $\mathrm{Yb}$ & - & - & $5.35(5.4)$ & 6.23 & - & - & - & - & - & 4.79 & 6.9 & 5.17 & 5.25 \\
\hline Lu & - & - & $0.88(0.79)$ & ) 1.12 & - & - & - & - & - & 0.77 & 1.03 & 0.79 & 0.80 \\
\hline
\end{tabular}

Notes: Single asterisk $(*)$ indicates total iron as $\mathrm{Fe}_{2} \mathrm{O}_{3}$; double asterisk $\left({ }^{* *}\right)$ indicates sum that does not include volatiles, dagger $(\dagger)$ indicates that major element analyses were performed on a volatile-free basis: dashes (197 indicate values that were not determined; values in parentheses by instrumental neutron activation from Australian National University, B.W. Chappell, analyst; other analyses as in text. BU = Boston University, WHOI $=$ Woods Hole Oceanographic Institution. $\mathrm{BDL}=$ below detection level. 
Table 7. Average composition of Hole 841B Subunit 2B rhyolites compared with other western Pacific dacites and rhyolites.

\begin{tabular}{|c|c|c|c|c|c|c|c|c|}
\hline \multirow{2}{*}{$\begin{array}{l}\text { Location: } \\
\text { Source: }\end{array}$} & \multirow{2}{*}{$\begin{array}{c}\text { Site } 841 \\
\text { Subunit 2B } \\
\\
\text { Average } \\
\text { Table } 5\end{array}$} & \multicolumn{2}{|c|}{ Lord Howe Rise } & \multirow{2}{*}{$\begin{array}{c}\text { Saipan } \\
\text { Boninitic } \\
\text { rhyolite } \\
\text { Meijer } \\
\text { (1983) }\end{array}$} & \multirow{2}{*}{$\begin{array}{c}\text { Site } 786 \\
61 \mathrm{R}-4, \\
96-102 \mathrm{~cm} \\
\text { Pearce et } \\
\text { al. (1992) }\end{array}$} & \multirow{2}{*}{$\begin{array}{c}\text { Site } 786 \\
67 \mathrm{R}-1, \\
33-41 \mathrm{~cm} \\
\text { Pearce et } \\
\text { al. (1992) }\end{array}$} & \multirow{2}{*}{$\begin{array}{c}\begin{array}{c}\text { Mariana } \\
\text { forearc }\end{array} \\
\text { Boninitic } \\
\text { dacite } \\
\text { Bloomer } \\
(1983)\end{array}$} & \multirow{2}{*}{$\begin{array}{c}\begin{array}{c}\text { Mariana } \\
\text { forearc }\end{array} \\
\begin{array}{c}\text { Tholeiitic } \\
\text { dacite }\end{array} \\
\text { Bloomer } \\
(1983)\end{array}$} \\
\hline & & $\begin{array}{l}\text { Average } \\
\text { Table } 5\end{array}$ & SD & & & & & \\
\hline \multicolumn{9}{|c|}{ Major elements (wt\%): } \\
\hline $\begin{array}{l}\mathrm{SiO}_{2} \\
\mathrm{TiO}_{2} \\
\mathrm{Al}_{2} \mathrm{O}_{3} \\
\mathrm{Fe}_{2} \mathrm{O}_{3} * \\
\mathrm{MnO} \\
\mathrm{MgO} \\
\mathrm{CaO} \\
\mathrm{Na}_{2} \mathrm{O} \\
\mathrm{K}_{2} \mathrm{O} \\
\mathrm{P}_{2} \mathrm{O}_{5} \\
\mathrm{Sum} \\
\mathrm{LOI}\end{array}$ & $\begin{array}{r}77.58 \\
0.22 \\
12.04 \\
2.19 \\
0.07 \\
0.26 \\
1.71 \\
4.46 \\
1.17 \\
0.03 \\
99.68 \\
5.42\end{array}$ & $\begin{array}{r}76.53 \\
0.20 \\
13.04 \\
2.21 \\
0.03 \\
0.39 \\
0.60 \\
3.03 \\
4.24 \\
0.03 \\
100.20 \\
7.21\end{array}$ & $\begin{array}{l}0.70 \\
0.03 \\
0.35 \\
0.28 \\
0.01 \\
0.24 \\
0.30 \\
0.18 \\
0.13 \\
0.01 \\
\\
1.92\end{array}$ & $\begin{array}{r}78.20 \\
0.17 \\
10.58 \\
1.47 \\
0.04 \\
0.22 \\
1.28 \\
3.54 \\
1.69 \\
0.12 \\
97.25 \\
3.00\end{array}$ & $\begin{array}{r}70.88 \\
0.32 \\
13.38 \\
4.63 \\
0.07 \\
0.56 \\
3.52 \\
4.84 \\
1.72 \\
0.08 \\
100.00 \\
2.93\end{array}$ & $\begin{array}{r}76.03 \\
0.23 \\
12.51 \\
2.60 \\
0.03 \\
0.40 \\
1.19 \\
4.25 \\
2.71 \\
0.05 \\
100.00 \\
0.69\end{array}$ & $\begin{array}{r}67.45 \\
0.19 \\
13.20 \\
5.57 \\
0.09 \\
3.55 \\
3.97 \\
3.78 \\
1.37 \\
0.06 \\
98.85 \\
1.4\end{array}$ & $\begin{array}{r}67.54 \\
0.56 \\
13.48 \\
7.14 \\
0.13 \\
0.81 \\
4.00 \\
3.34 \\
1.20 \\
0.16 \\
98.36 \\
2.24\end{array}$ \\
\hline \multicolumn{9}{|c|}{ Trace elements (ppm): } \\
\hline $\begin{array}{l}\mathrm{Zn} \\
\mathrm{Ni}\end{array}$ & $\begin{array}{r}39 \\
3\end{array}$ & ${ }^{150}$ & ${ }^{20}-$ & 1 & $\begin{array}{r}57 \\
4\end{array}$ & $\begin{array}{r}105 \\
3\end{array}$ & 24 & 8 \\
\hline $\mathrm{Cr}$ & 6 & 4 & 1 & 4 & 8 & 11 & 98 & 20 \\
\hline V & 4 & 3 & 0 & - & 38 & 22 & 85 & 21 \\
\hline $\mathrm{Cu}$ & 16 & - & - & - & 57 & 38 & - & - \\
\hline $\mathrm{Zr}$ & 173 & 373 & 74 & 125 & 81 & 77 & 76 & 99 \\
\hline Sc & 12 & 3 & 2 & - & 12 & 14 & - & - \\
\hline $\mathrm{Y}$ & 61 & 61 & 9 & & 15 & 12 & 7 & 34 \\
\hline $\mathrm{Sr}$ & 56 & 68 & 46 & 92 & 123 & 102 & 283 & 118 \\
\hline $\mathrm{Ba}$ & 190 & 538 & 444 & 175 & 175 & 430 & 42 & 31 \\
\hline $\mathrm{Rb}$ & 12 & 192 & 11.9 & 15 & 28 & 24 & 7 & 10 \\
\hline $\mathrm{Nb}$ & 1.4 & 32 & 3.6 & - & 1.39 & 0.85 & - & - \\
\hline Cs & 0.31 & 10.6 & 0.4 & - & 0.36 & - & - & - \\
\hline $\mathrm{U}$ & 0.27 & 3.74 & 0.13 & 0.85 & 0.43 & - & - & - \\
\hline Th & 0.41 & 14.6 & 1 & 1.6 & 0.83 & 0.52 & - & - \\
\hline $\mathrm{Pb}$ & 4.00 & 28.8 & 8.1 & - & 2.35 & 2.46 & - & - \\
\hline Co & 4 & 2.5 & 0.5 & - & - & - & - & - \\
\hline $\mathrm{Ta}$ & 0.10 & 1.79 & 0.12 & - & 0.12 & 0.06 & - & - \\
\hline Hf & 4.55 & 7.81 & 0.84 & - & 2.9 & 2.22 & - & - \\
\hline $\mathrm{La}$ & 4.28 & 59.4 & 10 & 5.50 & 4.53 & 3.06 & - & - \\
\hline $\mathrm{Ce}$ & 13.32 & 120 & 15 & 9.96 & 10.9 & 6.16 & 7.02 & 11.76 \\
\hline $\operatorname{Pr}$ & 2.36 & 15.3 & 2.7 & - & 1.42 & 0.81 & - & - \\
\hline $\mathrm{Nd}$ & 13.26 & 55.6 & 9.3 & 7.71 & 7.34 & 4.72 & 3.96 & 8.15 \\
\hline Sm & 4.94 & 12.4 & 1.9 & 2.48 & 1.88 & 1.35 & 1.00 & 2.62 \\
\hline $\mathrm{Eu}$ & 1.14 & 1.16 & 0.7 & 0.54 & 0.63 & 0.51 & 0.30 & 0.81 \\
\hline Gd & 6.96 & 12.2 & 1.6 & 3.31 & 2.43 & 1.42 & 0.98 & 3.98 \\
\hline $\mathrm{Tb}$ & 1.18 & 1.84 & 0.24 & - & 0.37 & 0.19 & - & - \\
\hline Dy & 8.46 & 10.3 & 1.3 & 3.42 & 2.50 & 1.53 & 0.86 & 4.52 \\
\hline Ho & 1.87 & 2.10 & 0.27 & - & 0.55 & 0.29 & - & - \\
\hline Er & 5.53 & 5.71 & 0.75 & 2.13 & 1.42 & 0.92 & 0.48 & 3.18 \\
\hline $\mathrm{Tm}$ & 0.91 & 0.86 & 0.12 & - & 0.24 & 0.18 & - & - \\
\hline $\mathrm{Yb}$ & 5.79 & 5.53 & 0.81 & 2.4 & 1.43 & 1.16 & - & 3.62 \\
\hline $\mathrm{Lu}$ & 1.00 & 0.85 & 0.11 & 0.43 & 0.23 & 0.13 & - & - \\
\hline
\end{tabular}

Notes: Single asterisk $\left({ }^{*}\right)$ indicates total iron as $\mathrm{Fe}_{2} \mathrm{O}_{3}$; dashes $(-)$ indicate values that were not determined. $\mathrm{SD}=$ standard deviation.

clear subduction signature, with enrichments in LILEs, low compatible-element concentrations, depletions in $\mathrm{Nb}$ and $\mathrm{Ta}$, and pronounced $\mathrm{Pb}$ enrichments (Fig. 10). They have low abundances of REEs as well as LREE depletions (Fig. 11). Temperatures calculated from coexisting magnetite and ilmenite in the rhyolite give temperatures of $906^{\circ} \mathrm{C}$ and oxygen fugacities of $10^{-11.82}$ (using the curves of Buddington and Lindsley [1964] with the recalculation procedure of Stormer [1983] and the fitting procedure of Ghiorso and Carmichael [1981]; Table 5). These data, as argued for similar Eocene rhyolites from Saipan, are most consistent with derivation of the rhyolites by fractional crystallization of a more mafic parent (Meijer, 1983). Rhyolites are not the product of hydrous melting of the mantle (Green, 1973) and the compatible element concentrations in the rhyolites are far too low for them to be mantle-derived melts. Melts of the downgoing slab should produce dacites (Ringwood, 1974) with pronounced heavy-rare-earth (HREE) depletions, because of equilibration with garnet eclogite, and LILE enrichments.

Melting of the altered lower oceanic crust beneath the Eocene forearc under hydrous conditions could produce rhyolites at $680^{\circ}-$ $720^{\circ} \mathrm{C}(\mathrm{Helz}, 1976)$. These melts, if the crust were in amphibolite facies conditions, should have higher $\mathrm{Al}_{2} \mathrm{O}_{3}$ ( Helz, 1976), more pronounced Eu depletions, greater LREE enrichments, and possibly higher HREE element "tails" than the Site 841 rhyolites. The crystallization temperatures for the rhyolites are also much higher than those for anatectites from a basaltic amphibolite $\left(680^{\circ}-720^{\circ} \mathrm{C}\right.$; Helz, 1976; Meijer, 1983).

However, Beard and Lofgren (1991) have recently shown that dehydration melting, rather than water-saturated melting, of greenstones at low pressures does produce melts very similar to low- $\mathrm{K}_{2} \mathrm{O}$ arc rhyolites at $850^{\circ}-900^{\circ} \mathrm{C}$. The restite from this melting lacks amphibole and includes plagioclase ( $>50$ modal $\%$ ), orthopyroxene and clinopyroxene. The experimental rhyolites with $78 \% \mathrm{SiO}_{2}$ have $12 \%$ $\mathrm{Al}_{2} \mathrm{O}_{3}, 2 \% \mathrm{CaO}, 0.5 \% \mathrm{TiO}_{2}$, and $0.5 \% \mathrm{MgO}$, values very similar to those in the Site 841 Subunit $2 \mathrm{~B}$ rhyolites. The Eu anomalies in the Subunit $2 \mathrm{~B}$ rhyolites are unusually small if they are indeed derived from partial melts that were in equilibrium with a plagioclase-rich residue. Also, production of the rhyolites by partial melting of the crust might be expected to produce a bimodal rock suite. However, the few analyses of arc clasts contained within the Site 841 rhyolites (see below) show a diverse range of $\mathrm{SiO}_{2}$ from $50 \%$ to $70 \%$, suggesting that the basement is not bimodal. However, the evidence for the 


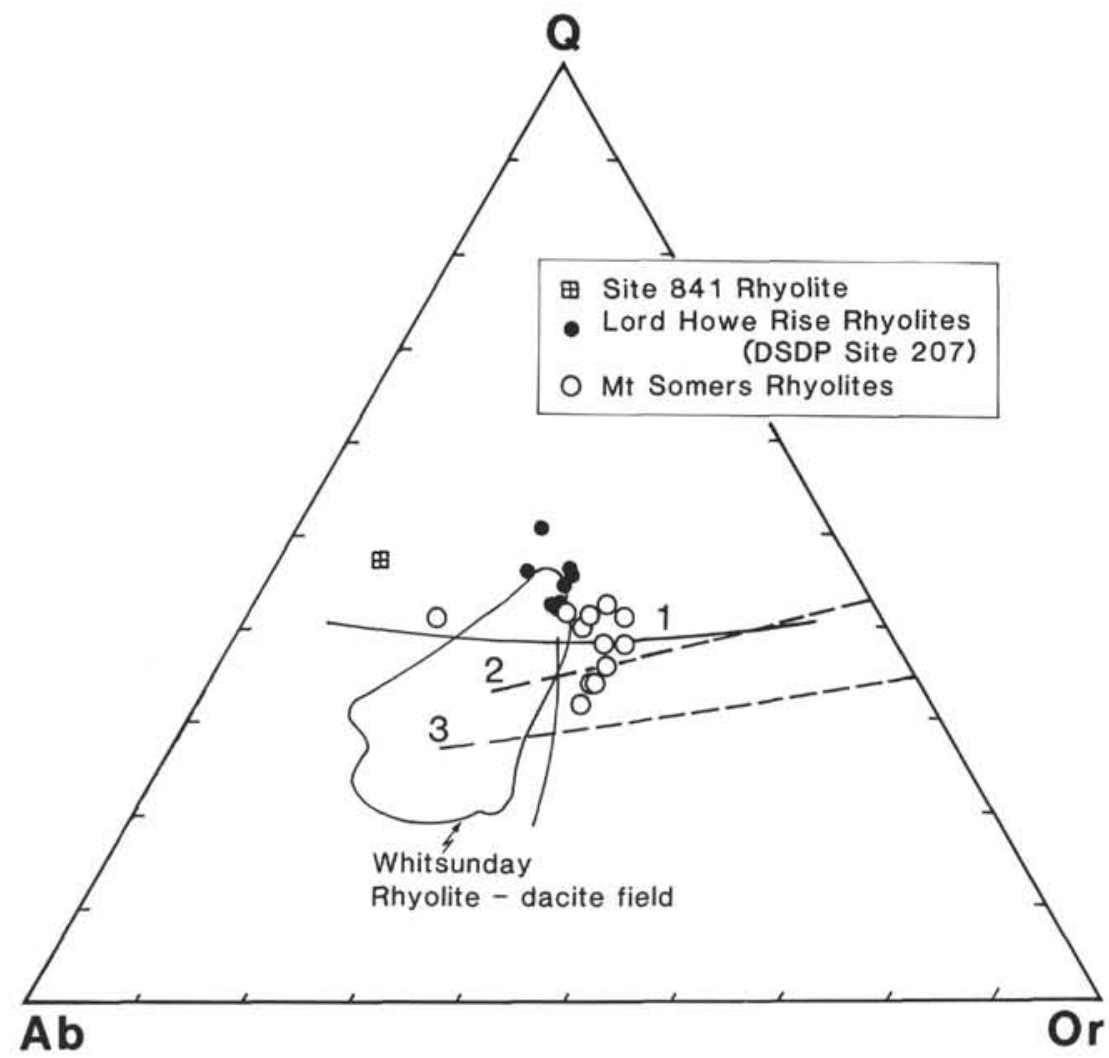

Figure 9. Q-Or-Ab normative projection for rhyolite compositions from the Southwest Pacific. Lord Howe Rise rhyolites (this paper), Whitsunday rhyolites in Queensland Province, Australia (Ewart et al., in press) and Mt. Somers rhyolites are all examples of Cretaceous rhyolitic fields associated with the fragmentation of the Southwest Pacific continental margins. Note the distinct compositions of the Site 841 rhyolite. Curve I is the water saturated curve at $100 \mathrm{MPa}$ for compositions of $\mathrm{An}_{3}$, after James and Hamilton (1969); curves 2 and 3 are the calculated 4-phase surfaces in the system Ab-An-Or-Q$\mathrm{H}_{2} \mathrm{O}$ for $\mathrm{a}_{w}=1.0$ and 0.2 , respectively, at $200 \mathrm{MPa}$ (after Nekvasil, 1988).

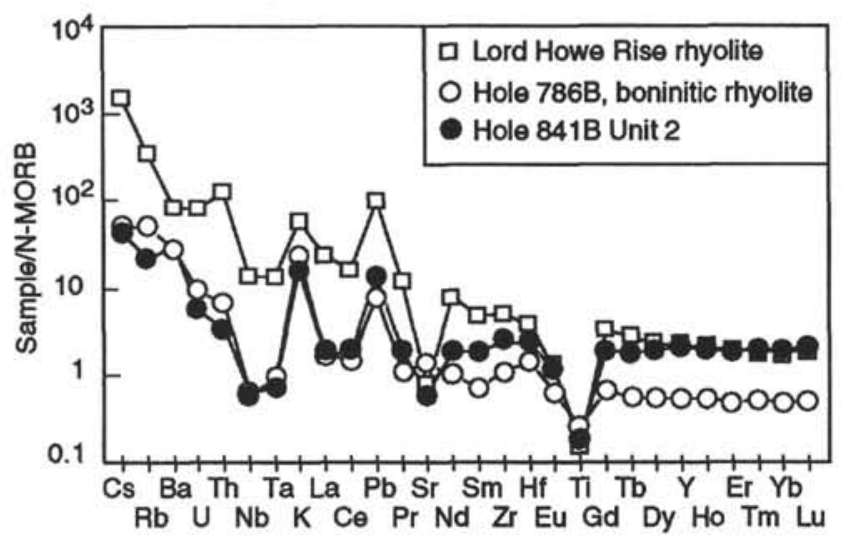

Figure 10. N-MORB-normalized compositions of Site 841 Subuit 2 B analyses, Lord Howe Rise rhyolites, and Site 786 boninitic dacite (Murton et al., 1992). Normalizing values from Sun and McDonough (1989).

basement composition is fragmentary and the possibility that the Site 841 rhyolites represent dehydration melting of lower arc crust cannot be ruled out.

The Site 841 rhyolites are, therefore, most reasonably interpreted as derivatives of a more mafic magma, requiring a substantial volume of mafic cumulates at depth, or as dehydration melts of lower arc crust, leaving a substantial granulite facies mafic residue. In either case, the parent material must have been very depleted in incompatible elements, given the low incompatible element abundances in the rhyolites. There are two mafic-silicic associations described from Eocene sequences in the Izu-Bonin-Mariana and Tonga forearcs. Boninitic series lavas have been described from a number of places in the IBM forearc (e.g., Hussong and Uyeda, 1982; Bloomer and Hawkins, 1987; Meijer, 1980; Reagan and Meijer, 1984; Ishii, 1985; Arculus et al., 1992; Pearce et al., 1992). These boninitic associations include dacitic and rhyolitic lavas (as on Saipan, first described by Schmidt [1957]) that are interpreted to have developed by fractional crystallization of a boninitic magma (Table 7; Meijer, 1983; Bloomer, 1987; Murton et al., 1992). Associated with these boninitic series, in time and space, are depleted island-arc-tholeiitic series lavas. These also include dacitic to rhyolitic fractionates (e.g., Bloomer, 1987; Murton et al., 1992) that are not as depleted in incompatible elements as their boninite series counterparts. Similar tholeiitic series basalts, andesites, dacites, and rhyolites comprise the Eocene basement on 'Eua (Ewart and Bryan, 1972; Hawkins and Falvey, 1985; Cunningham and Anscombe, 1985).

The rhyolites from Site 841 Subunit 2B show a closer similarity to tholeiite series lavas than to the boninite series. They are not as depleted in HREEs and HFSEs as are high-silica rocks derived from boninitic parents, such as those on Saipan and in Site 786 (Figs. 10 and 12). They are, however, very similar in element abundances and ratios to tholeiite series dacites from 'Eua (Fig. 12). In fact, they have trace element abundances nearly identical to the $73 \% \mathrm{SiO}_{2}$ volcanics on 'Eua (Table 7 and Fig. 12).

Stern et al. (1991) noticed that boninitic-series lavas in the Mariana forearc were characterized by high $\mathrm{K} / \mathrm{Ba}$ and low $\mathrm{Ba} / \mathrm{La}$, in 


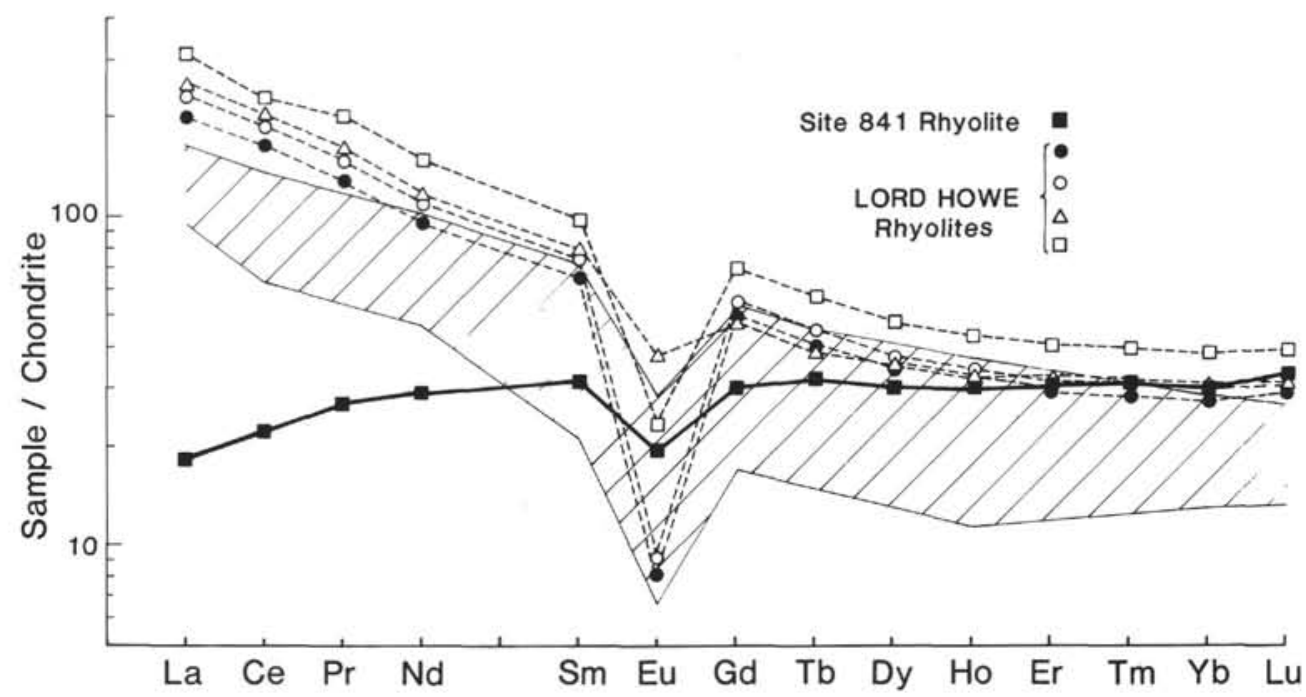

Figure 11. Chondrite-normalized, rare-earth-element diagrams for Site 841 rhyolite, Lord Howe Rise rhyolites, and rhyolites from the East Queensland Cretaceous Province (striped field, from Ewart et al., in press).
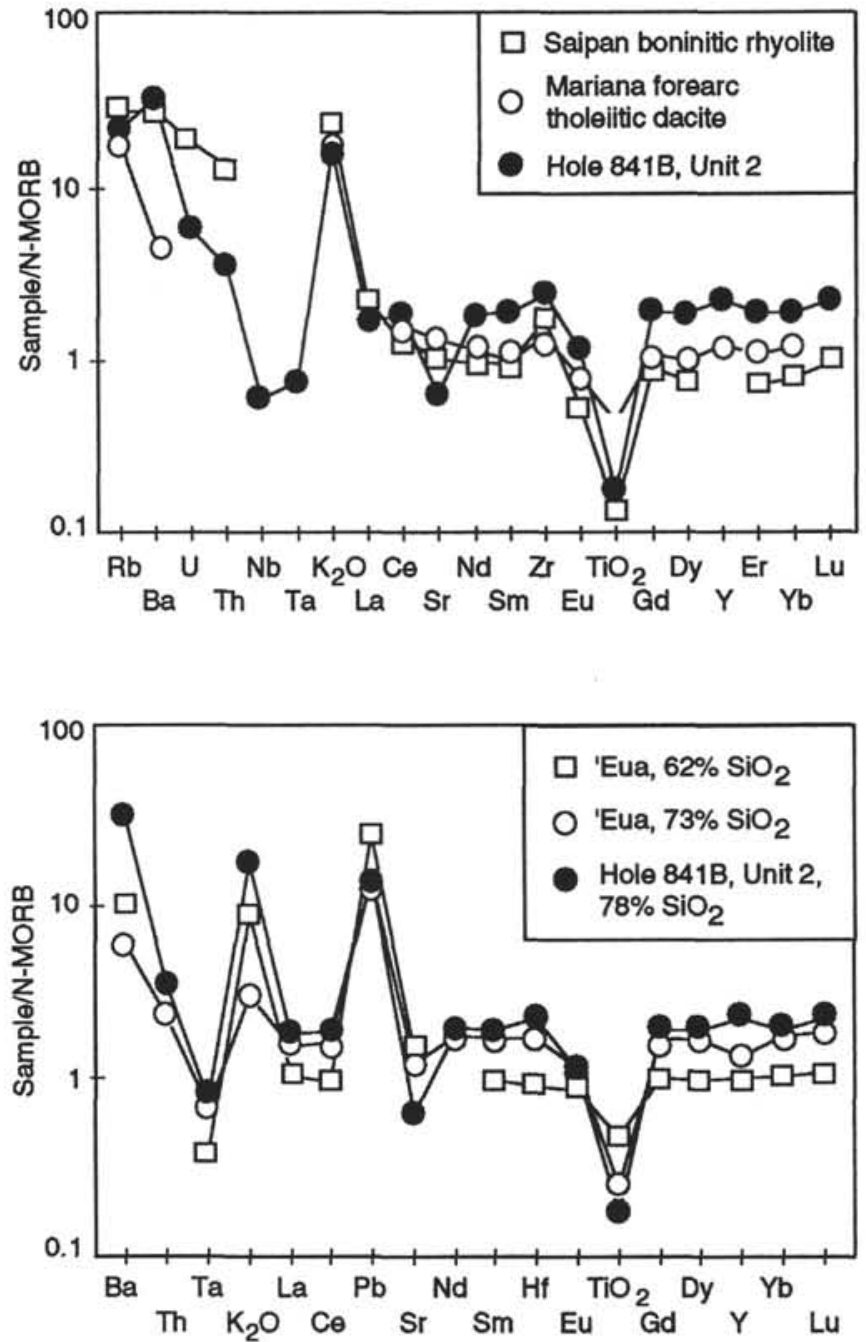

Figure 12. Hole 841B rhyolite compared to other siliceous Eocene forearc lavas. Normalizing values from Sun and McDonough (1989). Saipan analysis from Meijer (1983), Mariana forearc dacite from Bloomer (1987), and 'Eua analyses from Cunningham and Anscombe (1985).

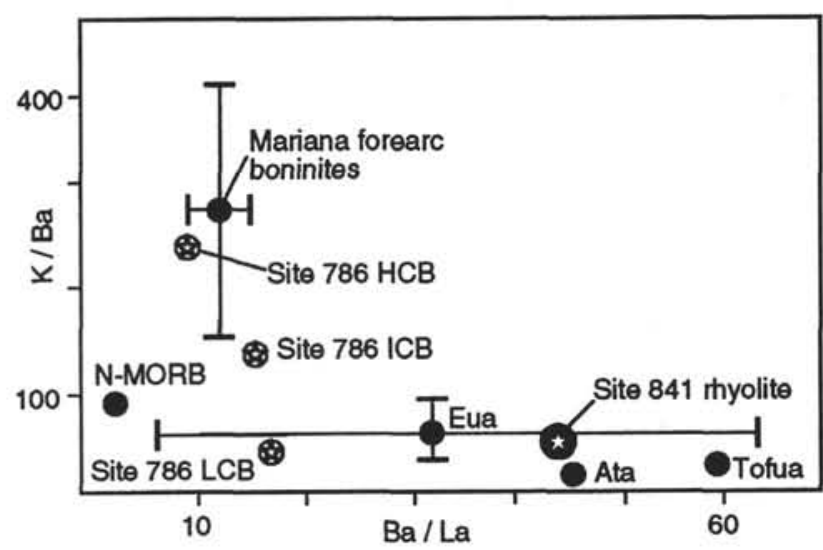

Figure 13. Trace element ratios for Site 841 lavas compared with boninite and lava on an island-arc-tholeiitic series. Average compositions for 'Ata and Tofua Arc from Ewart and Hawkesworth (1987); average and standard deviation for Mariana boninites from Stern et al. (1991), averages and standard deviations for 'Eua from Cunningham and Anscombe (1985), averages for Site 786 boninites from Murton et al. (1992; LCB = low-Ca boninite, ICB = intermediate-Ca boninites, and $\mathrm{HCB}=$ high-Ca boninite); N-MORB average from Sun and McDonough (1989).

contrast to the normal arc signature of high $\mathrm{Ba} / \mathrm{La}$ and low $\mathrm{K} / \mathrm{Ba}$ (Fig. 13). They suggested that this signature was unique to the boninitic eruptives that characterized the early phases of subduction. Indeed, the boninitic series at Site 786 show a low Ba/La signature, although $\mathrm{K} / \mathrm{Ba}$ varies between high-Ca and low-Ca boninites (Fig. 13). The Site 841 rhyolites have high $\mathrm{Ba} / \mathrm{La}$ and low $\mathrm{K} / \mathrm{Ba}$, suggesting an affinity to an arc-tholeiitic, not boninitic, magma stem.

\section{Volcanic Clast Compositions}

The extreme degree of fractionation of rhyolitic rocks makes it difficult to be specific about the nature of the parental lavas in the Eocene forearc. Furthermore, no information is available about the basement on which the silicic edifice was built. However, a variety of mafic clasts are present within the section at Site 841 that may provide a clue about the nature of both the parental lava for the rhyolites and about the basement beneath them.

We have examined three populations of clasts to search for information about the Eocene history of the forearc (Table 8). The first 
Table 8. Analyses of clasts from Hole 841B basement and sediments.

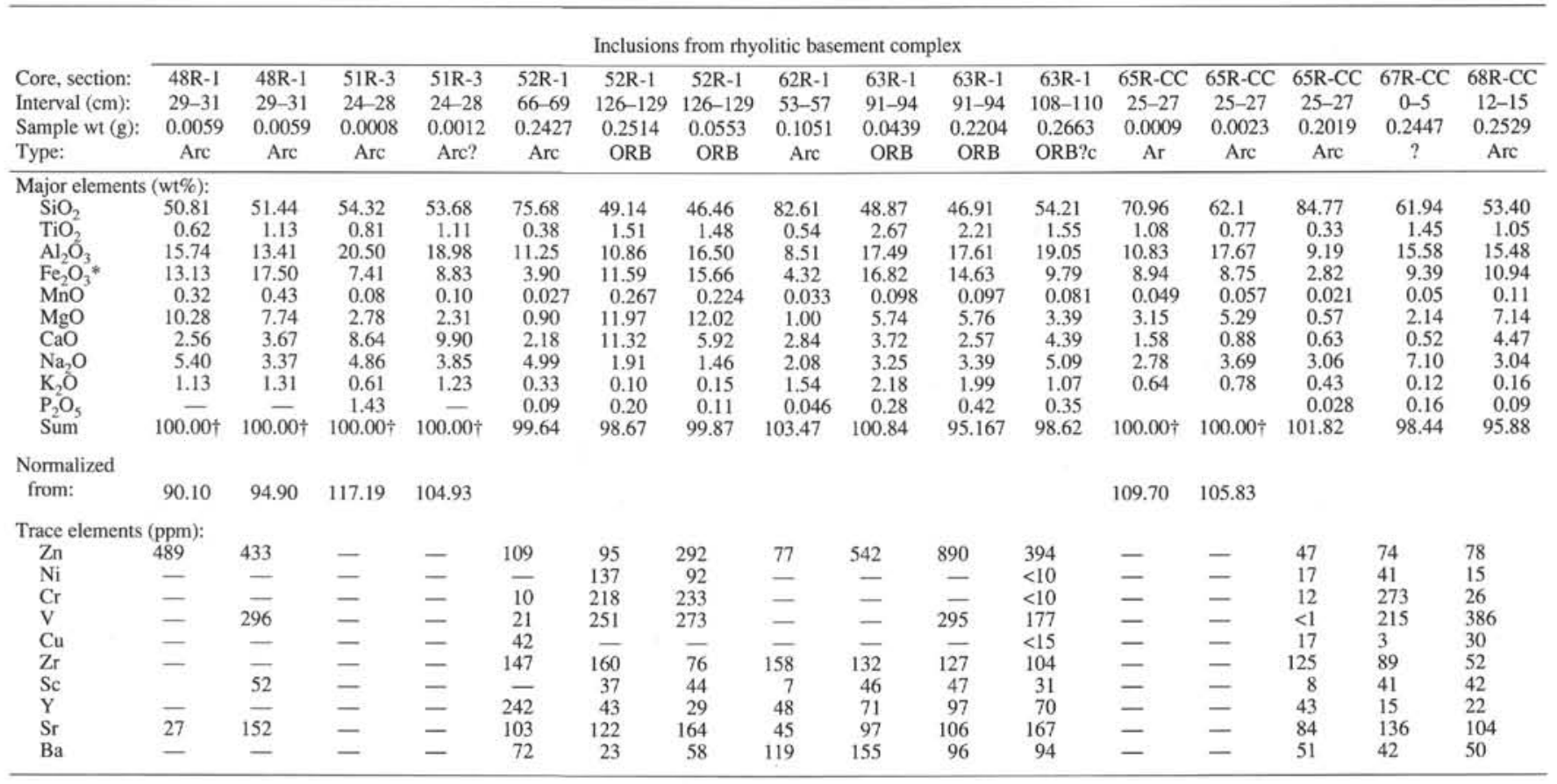

Table 8 (continued).

\begin{tabular}{|c|c|c|c|c|c|c|c|c|c|c|c|c|c|c|c|}
\hline \multirow{5}{*}{$\begin{array}{l}\text { Core, section: } \\
\text { Interval }(\mathrm{cm}) \text { : } \\
\text { Sample wt (g): } \\
\text { Type: }\end{array}$} & \multicolumn{2}{|c|}{$\begin{array}{l}\text { Inclusions from } \\
\text { Eocene sediments }\end{array}$} & & \multicolumn{3}{|c|}{$\begin{array}{l}\text { Inclusions from Oligocene } \\
\text { sediments }\end{array}$} & \multicolumn{9}{|c|}{ Inclusions from Miocene volcaniclastics with reworked Eocene fauna } \\
\hline & $45 \mathrm{R}-1$ & $46 \mathrm{R}-\mathrm{CC}$ & & $41 \mathrm{R}-\mathrm{CC}$ & $42 \mathrm{R}-2$ & $43 \mathrm{R}-1$ & 22R-2 & $22 \mathrm{R}-2$ & $22 \mathrm{R}-2$ & 22R-2 & 22R-2 & 22R-2 & $22 \mathrm{R}-2$ & $22 \mathrm{R}-2$ & $22 \mathrm{R}-2$ \\
\hline & $38-40$ & & & $15-20$ & $35-40$ & $116-119$ & $81-85$ & $81-85$ & $81-85$ & $81-85$ & $81-85$ & $81-85$ & $125-129$ & $125-129$ & $125-129$ \\
\hline & 0.0045 & 0.0012 & & 0.0047 & 0.0025 & 0.0057 & 0.0056 & 0.0022 & 0.0115 & 0.1257 & 0.0022 & 0.0829 & 0.2482 & 0.2451 & 0.1033 \\
\hline & Arc? & Arc & & Arc & Arc & Arc? & $?$ & $?$ & ORB? & Arc & Arc & Arc & Arc & ORB? & Arc \\
\hline \multicolumn{16}{|c|}{ Major elements (wt\%): } \\
\hline $\mathrm{SiO}_{2}$ & 51.50 & 48.28 & & 50.46 & 65.60 & 54.31 & 49.23 & 51.24 & 49.22 & 64.00 & 57.25 & 64.66 & 50.40 & 45.60 & 54.32 \\
\hline $\mathrm{TiO}_{2}^{2}$ & 1.07 & 0.87 & & 0.88 & 0.99 & 1.14 & 1.04 & 1.10 & 1.81 & 0.48 & 0.75 & 0.58 & 0.74 & 1.29 & 0.71 \\
\hline $\mathrm{Al}_{2} \mathrm{O}_{3}$ & 14.31 & 13.71 & & 16.13 & 16.99 & 14.39 & 18.39 & 15.62 & 16.52 & 16.48 & 14.42 & 12.08 & 15.20 & 18.64 & 18.71 \\
\hline $\mathrm{Fe}_{2} \mathrm{O}_{3}^{*}$ & 13.06 & 15.42 & & 11.45 & 6.75 & 11.64 & 10.91 & 14.87 & 14.22 & 4.59 & 11.64 & 10.66 & 12.00 & 14.37 & 11.37 \\
\hline $\mathrm{MnO}^{3}$ & 0.136 & 0.122 & & 0.274 & 0.53 & 0.177 & 0.223 & 0.241 & 0.163 & 0.052 & 0.13 & 0.13 & 0.252 & 0.22 & 0.16 \\
\hline $\mathrm{MgO}$ & 4.88 & 7.37 & & 7.28 & 0.71 & 5.32 & 6.49 & 6.77 & 3.83 & 1.29 & 4.09 & 3.38 & 9.31 & 15.45 & 3.19 \\
\hline $\mathrm{CaO}$ & 5.82 & 5.09 & & 6.46 & 4.27 & 9.18 & 9.76 & 4.17 & 10.42 & 2.67 & 4.80 & 3.18 & 1.71 & 2.10 & 2.60 \\
\hline $\mathrm{Na}_{2} \mathrm{O}$ & 3.32 & - & & 3.20 & 2.46 & 2.82 & 4.03 & 5.00 & 3.13 & 7.37 & 4.18 & 2.22 & 5.82 & 2.09 & 8.70 \\
\hline $\mathrm{K}_{2} \mathrm{O}$ & 1.53 & - & & 1.11 & 1.83 & 1.02 & 0.19 & 0.99 & 0.77 & 0.42 & 2.73 & 3.12 & 0.22 & 0.23 & 0.25 \\
\hline $\mathrm{P}_{2} \mathrm{O}_{5}$ & - & - & & - & 0.66 & 0.46 & - & 0.67 & 0.09 & 0.07 & 8.01 & 0.19 & 0.25 & 0.15 & 0.06 \\
\hline Sum & 95.63 & 90.86 & & 97.24 & $100.00 \div$ & $100.00 \dagger$ & 100.26 & $100.00 \dagger$ & $100.00 \dagger$ & 97.35 & $100.00 \div$ & $100.00 \dagger$ & 95.65 & $100.00 \dagger$ & $100.00 \dagger$ \\
\hline \multirow{2}{*}{\multicolumn{16}{|c|}{$\begin{array}{l}\text { Normalized } \\
\text { from: }\end{array}$}} \\
\hline & & & & & 109.69 & 105.00 & & 107.50 & 105.12 & & 108.70 & 94.64 & & 91.95 & 93.15 \\
\hline \multicolumn{16}{|c|}{ Trace elements (ppm): } \\
\hline $\mathrm{Zn}$ & 252 & - & - & 263 & - & 232 & 180 & - & 82 & 31 & - & 90 & 190 & 99 & 77 \\
\hline $\mathrm{Ni}$ & - & - & - & - & - & - & 229 & - & 183 & 7 & - & 18 & 115 & 153 & 20 \\
\hline $\mathrm{Cr}$ & - & - & - & - & - & - & 180 & - & 39 & 7 & - & 35 & 413 & 470 & 13 \\
\hline V & 322 & - & - & - & - & 355 & - & - & 392 & 84 & - & 187 & 181 & 323 & 206 \\
\hline $\mathrm{Cu}$ & - & - & - & 272 & - & 695 & - & - & - & 19 & - & 27 & 30 & 5 & 43 \\
\hline $\mathrm{Zr}$ & - & - & - & - & - & - & - & - & - & 38 & - & 35 & 45 & 90 & 42 \\
\hline $\mathrm{Sc}$ & 53 & - & - & - & - & 65 & - & - & 40 & 14 & - & 22 & 32 & 45 & 30 \\
\hline $\mathrm{Y}$ & - & - & - & - & - & - & - & - & - & 15 & - & 38 & 34 & 21 & 11 \\
\hline $\mathrm{Sr}$ & 208 & - & - & 207 & - & 189 & 148 & - & 264 & 58 & - & 79 & 98 & 63 & 56 \\
\hline $\mathrm{Ba}$ & 278 & - & - & 318 & - & 269 & 258 & - & 261 & 93 & - & 697 & 41 & 42 & 63 \\
\hline
\end{tabular}

group comprises clasts contained within the rhyolites. These include aphyric greenstones, mafic grains and pebbles, and silicic pebbles. Similar clasts occur within the Oligocene and Eocene sediments immediately overlying the rhyolites. A third group of clasts comes from a Miocene breccia/conglomerate sequence in which there is a reworked Eocene fauna, indicating that Eocene basement was locally exposed during sedimentation. Many of these clasts are extensively altered, and their mobile element concentrations are suspect; also many were too small to allow analysis of trace elements.

The compositions of the clasts are shown in Figure 14, compared to fields for their most likely sources. The field for 'Eua represents basaltic to rhyolitic Eocene arc compositions, whereas fields for E- 
Table 8 (continued)

\begin{tabular}{|c|c|c|c|c|c|c|c|c|c|c|}
\hline \multicolumn{11}{|c|}{ Inclusions from Miocene Volcaniclastics with reworked Eocene fauna } \\
\hline Core, section: & $22 \mathrm{R}-2$ & 23R-1 & $23 \mathrm{R}-1$ & $23 \mathrm{R}-2$ & 24R-CC & 24R-CC & $29 \mathrm{R}-1$ & 29R-1 & $29 \mathrm{R}-1$ & $29 \mathrm{R}-1$ \\
\hline Interval $(\mathrm{cm})$ : & $125-129$ & $12-14$ & $12-14$ & $113-115$ & $13-15$ & $13-15$ & $52-54$ & $52-54$ & $71-73$ & $71-73$ \\
\hline Sample wt $(\mathrm{g})$ : & 0.0234 & 0.2149 & 0.0058 & 0.0056 & 0.2604 & 0.1141 & 0.0366 & 0.0147 & 0.1367 & 0.0079 \\
\hline Type: & ORB? & Arc & Arc & $?$ & ORB? & Arc? & ORB? & $?$ & Arc & ORB \\
\hline \multicolumn{11}{|c|}{ Major elements (wt $\%$ ): } \\
\hline $\mathrm{SiO}_{2}$ & 48.35 & 51.38 & 53.16 & 53.78 & 50.13 & 54.27 & 52.54 & 50.88 & 53.24 & 48.81 \\
\hline $\mathrm{TiO}_{2}$ & 1.03 & 0.62 & 0.56 & 1.03 & 1.13 & 1.01 & 1.40 & 1.17 & 0.74 & 2.19 \\
\hline $\mathrm{Al}_{2} \mathrm{O}_{3}$ & 14.61 & 17.02 & 20.78 & 14.90 & 16.51 & 14.85 & 15.99 & 14.68 & 13.77 & 15.31 \\
\hline $\mathrm{Fe}_{2} \mathrm{O}_{3}{ }^{*}$ & 15.67 & 16.15 & 9.55 & 12.32 & 12.93 & $\begin{array}{l}12.76 \\
12.76\end{array}$ & 15.14 & 15.55 & 15.88 & 15.63 \\
\hline $\mathrm{MnO}$ & 0.31 & 0.29 & 0.15 & 0.19 & 0.29 & 0.26 & 0.22 & 0.24 & 0.23 & 0.20 \\
\hline $\mathrm{MgO}$ & 8.25 & 6.47 & 3.19 & 3.71 & 5.16 & 4.12 & 3.77 & 5.84 & 6.95 & 9.39 \\
\hline $\mathrm{CaO}$ & 5.90 & 1.92 & 4.15 & 6.36 & 10.27 & 8.38 & 3.64 & 4.62 & 3.92 & 4.55 \\
\hline $\mathrm{Na}_{2} \mathrm{O}$ & 4.11 & 5.41 & 7.42 & 4.58 & 3.48 & $\begin{array}{l}0.30 \\
3.87\end{array}$ & 5.91 & 6.00 & 4.09 & 3.82 \\
\hline $\mathrm{K}_{2} \mathrm{O}$ & 0.70 & 0.74 & 1.04 & 0.84 & 0.11 & 0.20 & 1.38 & 0.65 & 1.16 & 0.04 \\
\hline $\mathrm{P}_{2} \mathrm{O}_{5}$ & 0.25 & 0.03 & - & 0.21 & 0.26 & 0.07 & 0.09 & 0.42 & 0.16 & 1.00 \\
\hline Sum & 98.93 & $100.00 \div$ & $100.00 \dagger$ & 97.71 & $100.00 \dagger$ & 99.72 & $100.00 \dagger$ & 99.63 & $100.00 \dagger$ & $100.00^{4}$ \\
\hline \multicolumn{11}{|l|}{ Normalized } \\
\hline from: & & 92.06 & 94.56 & & 90.75 & & 94.23 & & 91.47 & 108.00 \\
\hline \multicolumn{11}{|c|}{ Trace elements $(\mathrm{ppm})$ : } \\
\hline $\mathrm{Zn}$ & 150 & 153 & 152 & 171 & 122 & 97 & 168 & 156 & 195 & 161 \\
\hline $\mathrm{Ni}$ & 110 & 34 & - & - & 29 & 24 & 13 & 120 & 52 & 147 \\
\hline & 360 & 7 & - & - & 31 & 28 & 2 & 21 & 71 & 181 \\
\hline $\mathrm{v}$ & 165 & 251 & - & 331 & 436 & 229 & 517 & 238 & 303 & 228 \\
\hline $\mathrm{Cu}$ & & & - & - & 109 & - & 13 & - & 15 & - \\
\hline $\mathrm{Zr}$ & 99 & 49 & - & - & 80 & 63 & 62 & - & 25 & - \\
\hline $\mathrm{Sc}$ & 40 & 24 & - & - & 43 & 37 & 35 & 72 & 24 & 30 \\
\hline $\mathrm{Y}$ & 47 & 15 & - & 49 & 30 & 24 & 30 & - & 39 & - \\
\hline $\mathrm{Sr}$ & 81 & 52 & 74 & 179 & 257 & 213 & 117 & 53 & 2232 & 21 \\
\hline $\mathrm{Ba}$ & $\begin{array}{r}187 \\
\end{array}$ & 133 & 400 & 380 & 87 & 112 & 98 & 88 & 930 & - \\
\hline
\end{tabular}

Notes: Single asterisk $\left({ }^{*}\right)$ represents total iron as $\mathrm{Fe}_{2} \mathrm{O}_{3}$; dashes $(\mathrm{M})$ indicate values that were not determined. Some small samples yielded sums between $90 \%$ and $120 \%$ because of weighing errors or because of very high volatile contents caused by alteration. These analyses were normalized to $100 \%$ (noted by $\dagger$ ); the original sum is noted below each analysis. Volumes of small samples were insufficient to allow complete trace element analysis. Type designations are based on empirical comparison to the fields in Figure 13 and discriminant analysis using $\mathrm{Ti}, \mathrm{V}, \mathrm{CaO}, \mathrm{Fe}_{2} \mathrm{O}_{3}, \mathrm{MgO}_{\text {, }}$ $\mathrm{SiO}_{2}$, and $\mathrm{Sr} . \mathrm{ORB}=$ ocean ridge basalts, Arc = compositions similar to Eocene volcanics on 'Eua, and ? = clasts that could not be assigned a definitive origin.

MORB and N-MORB from the subducting Pacific Plate east of the Tonga Trench (Bloomer and Fisher, 1987) represent reasonable compositions for the basement on which the Eocene arc might have been built. The origins assigned to the clasts in Table 8 are based on comparison of the clast compositions to these fields (empirically and by discriminant analysis).

Two groups of clast types can be identified (Table 8 and Fig. 14); some of the clasts cannot be confidently assigned to either group. The principal population includes basalts, andesites, and dacites with low $\mathrm{TiO}_{2}$ and low Ti/V that are clearly of arc origin (Table 8). None of this population has the low $\mathrm{Ti}, \mathrm{Ca}$, and $\mathrm{Al}$ signatures typical of boninitic series lavas, supporting the conclusion that the Site 84 l volcanic complex is part of an arc-tholeiitic magma series.

The second population is small, but appears to comprise clasts of ocean ridge basalt composition. These clasts have $\mathrm{TiO}_{2}$ greater than $1.4 \%$ (some greater than $2 \%$ ), high $\mathrm{Ni}$ and $\mathrm{Cr}$ concentrations, and high $\mathrm{Ti} / \mathrm{V}$. Some of the highest Ti samples may represent enriched MORB or intraplate compositions, which do exist in the offshore plate (Bloomer and Fisher, 1987). These ocean-ridge-like clasts occur in both the reworked Miocene sediments and within the rhyolitic basement. The latter group is very significant, as it means that mid-ocean-ridge crust existed beneath the rhyolitic arc edifice that built the Site 841 basement.

\section{Discussion}

The rhyolitic complex found at Site 841 was one of the most surprising discoveries of Leg 135. There are a number of similarities between this arc sequence and Eocene arc lavas that have been drilled in the forearcs of the IBM systems. The Site 841 rhyolites appear to be mid-Eocene in age, on the basis of the age of the overlying sediments and preliminary $\mathrm{K}-\mathrm{Ar}$ ages. The IBM basement is all part of a middle to late Eocene construct (Taylor, 1992). The rhyolitic magma at Site 841 was derived by fractional crystallization of a more mafic, arc-tholeiitic lava, very similar to volcanic rocks in the Eocene basement on 'Eua or by dehydration melting of similar Eocene volcanic rocks in the arc basement. The IBM forearc is a composite of low-Ca to high-Ca boninites and depleted arc-tholeiite-series lavas (Natland and Tarney, 1981; Bloomer, 1983, 1987; Arculus et al., 1992; Murton et al., 1992; Taylor, 1992). Boninitic lavas have not been found with any of the igneous rocks on 'Eua or at Site 841; they have been dredged from the northern termination of the Tonga arc, but the measured age of those boninites is much younger than Eocene. Boninitic rocks have not been found in most of the Tonga forearc, though the volume of dredge and drill sampling in most of the forearc is still so sparse that their existence cannot be ruled out.

The basement at Site 841 has subsided over $5000 \mathrm{~m}$ since the late Eocene. This remarkably large subsidence is a consequence both of thermal subsidence and of subduction erosion. Substantial subsidence has been documented for forearc sites in the IBM system (Lagabrielle et al., 1992; Taylor, 1992). The boninitic volcano drilled at Site 786 in the Bonin forearc is also inferred to have been above sea level in the Eocene (Lagabrielle et al., 1992).

The results from Site 841 also support hypotheses for forearc evolution proposed in the IBM system. There the initiation of subduction was accompanied by the development of a very wide (up to $300 \mathrm{~km}$ ) and extensive (up to $3000 \mathrm{~km}$ long) zone of arc volcanism in the middle to late Eocene (Natland and Tarney, 1981; Taylor, 1992; Stern and Bloomer, 1992). This style of volcanism is required by the distribution of middle to late Eocene arc volcanics in the forearcs and frontal arcs. This Eocene volcanism developed in an extensional en- 

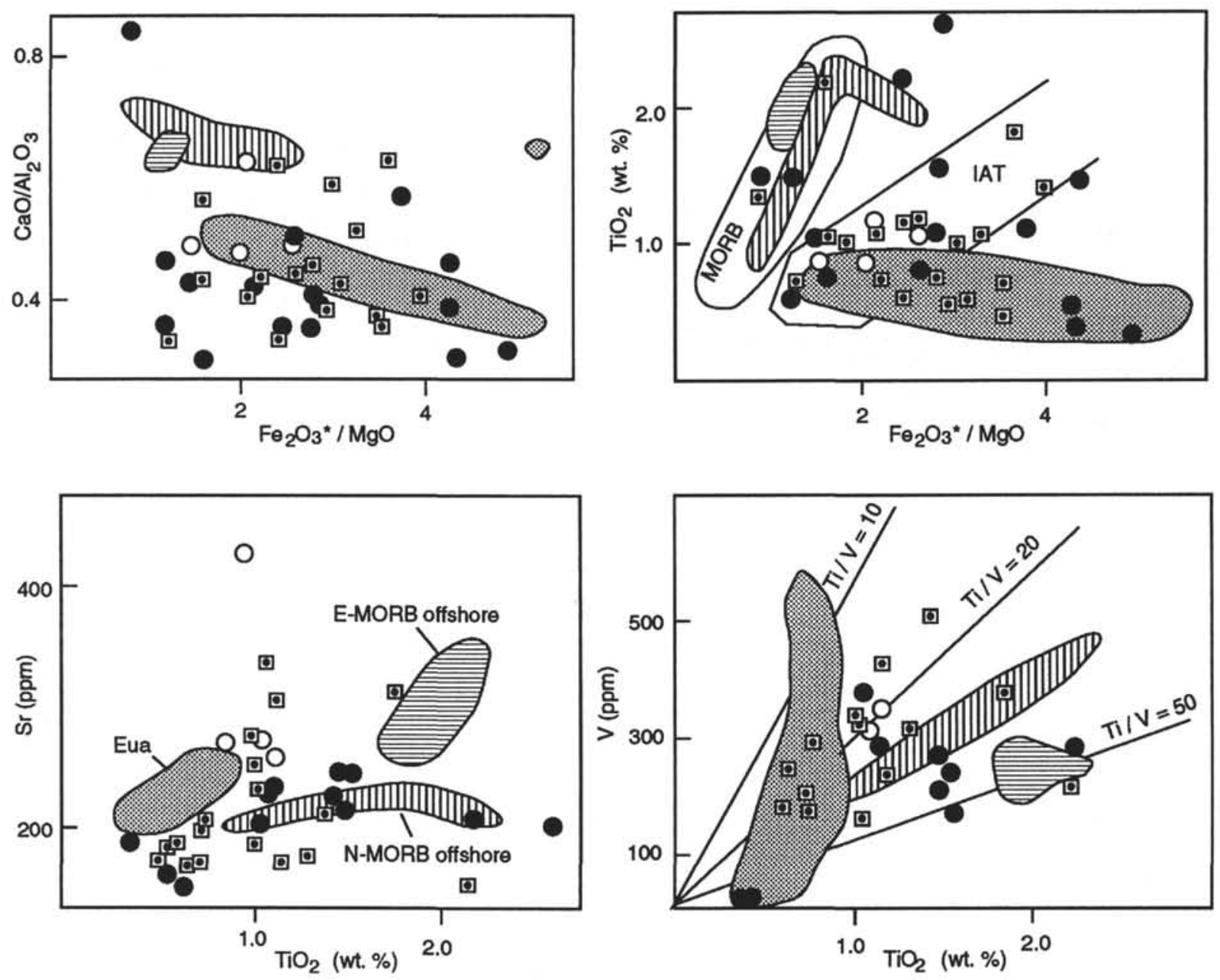

Figure 14. Compositions of clasts in Site 841 sections. Solid circles = clasts within the rhyolitic basement (Units 2-6); open circles $=$ clasts from Eocene-Oligocene calcareous sandstones: and dotted squares = clasts within Miocene sediments that contain reworked Eocene fauna. Fields for Eocene arc lavas on 'Eua from Cunningham and Anscombe (1985); fields for N-MORB and E-MORB, which form the Pacific Plate in the Tonga Trench, from Bloomer and Fisher (1987).

vironment, and in places may have occurred as true seafloor spreading (Stern and Bloomer, 1992).

A similar model can be applied to the Tonga forearc. Site 841 on the trench-slope break, and the basement on 'Eua at the edge of the Tonga platform, bracket a zone at least $65 \mathrm{~km}$ wide, on both sides of which identical lavas were erupted at 46-40 Ma. Arc lavas and plutonics are the principal materials dredged from the landward trench slope from the Louisville Seamount Chain intersection all the way to the north end of the trench (Fig. 1), a distance of over $1000 \mathrm{~km}$. The occurrence of ocean-ridge basalt clasts within the rhyolites at Site 841 is significant, because it requires that the older oceanic crust on which the Eocene arc was building had been rifted, but that crust was not completely replaced by juvenile arc volcanism. The age of the basement in the forearc is only well constrained at Site 841 and on 'Eua. Additional sampling is essential if we are to confirm that the Tonga forearc is indeed constructed in the same manner as the IBM forearc systems. However, the available evidence is completely consistent with the model for forearc evolution that has been proposed by Stern and Bloomer (1992) (Fig. 15).

This model supposes that subduction zones begin by sinking of old, unstable lithosphere, perhaps initiated at a fracture zone. The initial "subduction" is entirely a vertical movement (Fig. 15). A consequence of that sinking is a strong trench "suction" that extends the upper plate and begins to rift apart the preexisting oceanic crust.
Dehydration of the sinking slab initiates melting in the extending lithosphere, augmented by an influx of asthenosphere driven by the sinking lithosphere. This melting generates boninitic and arc-tholeiitic sequences. The dominant magma product depends upon the initial thermal structure of the mantle and the degree of depletion of the preexisting lithosphere. Highly depleted lithosphere produces boninitic-series melts; less depleted, perhaps deeper lithosphere and the inflowing asthenosphere produce arc-tholeiitic melts. These arc eruptives build atop the rifted oceanic crust. Zones of particularly high magma supply may yield subaerial volcanic edifices like those found at Site 841 and on Saipan (Meijer, 1980). If the degree of extension is sufficiently high, the arc volcanism may proceed in a seafloor spreading mode (Stern and Bloomer, 1992). That stage was apparently not reached beneath Site 841 .

The results from Site 841 provide strong support for the models of forearc evolution that have been proposed for the IBM system. The earliest phases of subduction in the Tonga region appear to have been accompanied by broadly distributed island arc-tholeiitic volcanism.

\section{SUMMARY}

The basement at Site 841 comprises over $200 \mathrm{~m}$ of rhyolites, pumice breccias, and tuffs that are part of a middle to late Eocene subaerial island-arc volcano. The rhyolites were derived by fractional 

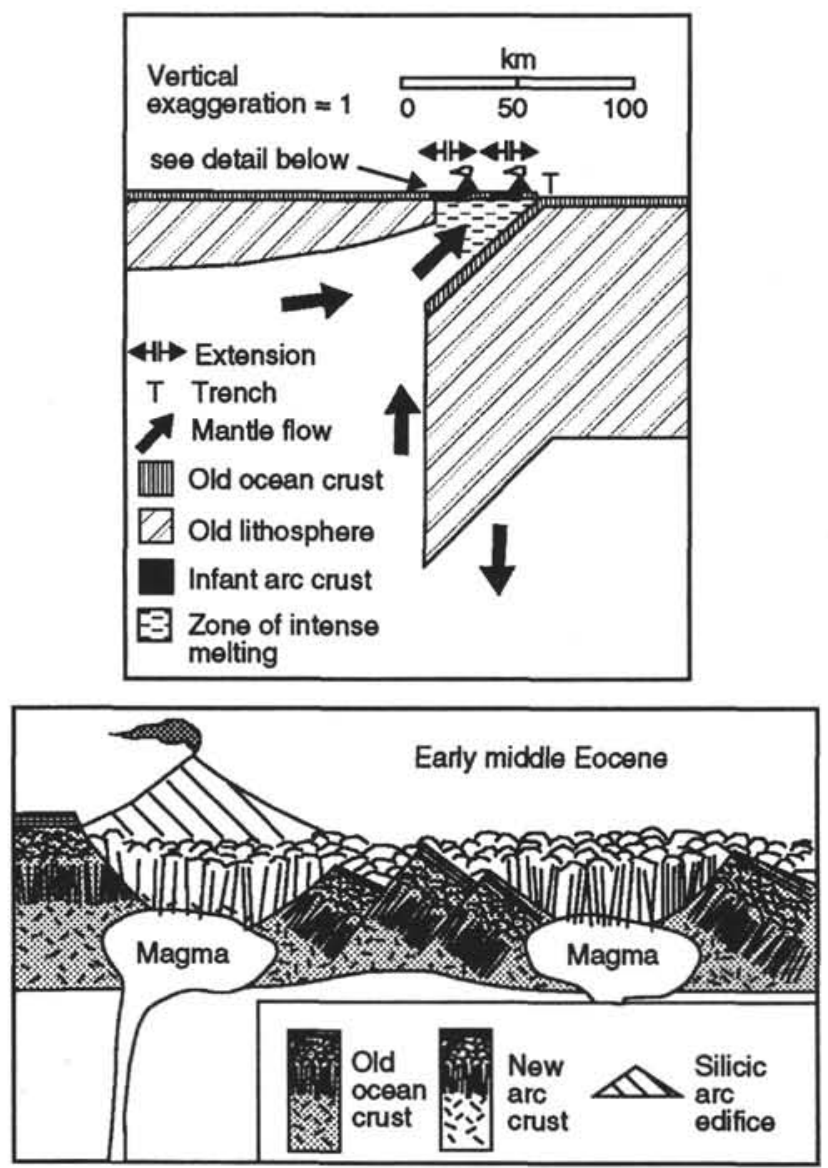

Figure 15. Model ror the initial phases of subduction (after Stern and Bloomer, 1992). Subduction is initiated by sinking of old lithosphere, producing extension in the overlying oceanic plate and melting in the mantle wedge (lithosphere and inflowing asthenosphere) above the sinking plate. Arc lavas erupt on, and cover, extended ocean crust. Sites of large magma supply may develop silicic, subaerial edifices.

crystallization of a more mafic arc-tholeiitic parent (implying a significant volume of mafic cumulates at depth) or by dehydration melting of lower arc crust (implying a substantial granulite facies mafic residue at depth). The Site 841 rhyolites are nearly identical to high- $\mathrm{SiO}_{2}$ lavas in the Eocene basement on 'Eua and are not the same as the Cretaceous rhyolites on the Lord Howe Rise, and are not part of a pre-Eocene crustal fragment.

The age and composition of the Site 841 rhyolites, and their position $65 \mathrm{~km}$ outboard of same-aged rocks on 'Eua supports models for forearc development that require an early episode of broadly distributed arc volcanism. Clasts of ocean-ridge basalt within the rhyolites suggests that the Eocene volcano was built on rifted oceanic crust.

Unlike the Mariana forearc, no evidence was found at Site 841 for extensive exposures of serpentine in the forearc. Such diapiric bodies may not exist here, or they may be too far away to have shed debris into the sedimentary section at Site 841 .

Basaltic dikes and sills intrude upper lower Miocene and midMiocene sediments at Site 841. These basalts appear to be part of one intrusive episode; they are identical to upper Miocene lavas erupted on the Lau Ridge and show no geochemical signature to suggest that they were generated by anomalous melting in the sub-forearc mantle. We consider it most likely that these intrusions were fed from basement dikes propagating out from the Miocene active arc. A similar origin is suggested for forearc basin intrusions in the Mariana and Bonin forearcs.

\section{ACKNOWLEDGMENTS}

We thank the technicians, crew, and drillers aboard Leg 135 for their enthusiasm and skill during the drilling at Site 841. Our ideas about forearc evolution have benefited from discussions with Bob Stern, Julian Pearce, Brian Taylor, Kristen Nilsson, Jim Hawkins, Patty Fryer, and Tony Crawford. Shawn Dolan and Jennifer Chase provided invaluable assistance with the analyses of the Site 841 samples. We would also like to thank members of the Western Pacific Panel; David Scholl, Tracy Vallier, and Andy Stevenson of the U.S. Geological Survey; and Jim Hawkins for their efforts in including Site 841 in the Leg 135 prospectus. Careful reviews by Robert Stern, Richard Arculus, and James Hawkins improved the final manuscript. This work was supported by a grant from JOI-USSAC.

\section{REFERENCES}

Acland, A.S., Vysotsky, S.V., Pearce, J.A., and Parson, L.M., 1992. Geochemistry of a boninitic crustal section from the northern Tonga Trench [presented at Back-Arc Development and Crustal Accretion in the Western Pacific, Cambridge, England, May 1990]. (Abstract)

Arculus, R.J., Pearce, J.A., Murton, B.J., and van der Laan, S.R., 1992. Igneous stratigraphy and major-element geochemistry of Holes 786A and 786B. In Fryer, P., Pearce, J.A., Stokking, L.B., et al., Proc. ODP, Sci. Results, 125: College Station, TX (Ocean Drilling Program), 143-169.

Beard, J.S., and Lofgren, G.G., 1991. Dehydration melting and water-saturated melting of basaltic and andesitic greenstones and amphibolites at I, 3 and 6.9 kb. J. Petrol., 32:365-401.

Bentz, F.P., 1974. Marine geology of the southern Lord Howe Rise, southwest Pacific. In Burk, C.A., and Drake, C.L. (Eds.), The Geology of Continental Margins: New York (Springer-Verlag), 537-547.

Billington, S., 1980. The morphology and tectonics of the subducted lithosphere in the Tonga-Kermadec-Fiji region from seismicity and focal mechanism solutions [Ph.D. dissert.]. Cornell Univ., Ithaca, NY.

Bloomer, S.H.. 1983. Distribution and origin of igneous rocks from the landward slopes of the Mariana Trench: implications for its structure and evolution. J. Geophys. Res., 88:7411-7428.

-1987. Geochemical characteristics of boninite- and tholeiite-series volcanic rocks from the Mariana forearc and the role of an incompatible element-enriched fluid in arc petrogenesis. Spec. Pap.-Geol. Soc. Am., 215:151-164.

Bloomer, S.H., and Fisher, R.L., 1987. Petrology and geochemistry of igneous rocks from the Tonga Trench-a nonaccreting plate boundary. J. Geol.. 95:469-495.

Bloomer, S.H., and Hawkins, J.W., 1987. Petrology and geochemistry of boninite series volcanic rocks from the Mariana trench. Contrib. Mineral. Petrol., 97:361-377.

Bloomer, S.H., Parsons, L., Huggett, Q., and Pearce, J., 1988. GLORIA surveys of the Tonga and Kermadec Trenches. Eos, 69:1442.

Bloomer, S.H., Stern, R.J., Fisk, E., and Geschwind, C.H., 1989. Shoshonitic volcanism in the northern Mariana Arc, 1. Mineralogy and major and trace element characteristics. J. Geophys. Res., 94:4469-4496.

Buddington, A.F., and Lindsley, D.H., 1964. Iron-titanium oxides minerals and synthetic equivalents. J. Petrol., 5:310-357.

Burns, R.E., and Andrews, J.E., 1973. Regional aspects of deep sea drilling in the southwest Pacific. In Burns, R.E.. Andrews, J.E., et al., Init. Repts. DSDP, 21: Washington (U.S. Govt. Printing Office), 897-906.

Cole, J.W., Gill, J.B., and Woodhall, D., 1985. Petrologic history of the Lau Ridge, Fiji. In Scholl, D.W., and Vallier, T.L. (Eds.), Geology and Offshore Resources of Pacific Island Arcs-Tonga Region. Circum-Pac. Counc. Energy Miner. Resour., Earth Sci. Ser., 2:379-414.

Cole, J.W., Graham, I.J., and Gibson, I.L., 1990. Magmatic evolution of Late Cenozoic volcanic rocks of the Lau Ridge, Fiji. Contrib. Mineral. Petrol., 104:540-554.

Cunningham, J.K., and Anscombe, K.J., 1985. Geology of 'Eua and other islands, Kingdom of Tonga. In Scholl, D.W., and Vallier, T.L. (Eds.), Geology and Offshore Resources of Pacific Island Arcs-Tonga Region. Circum-Pac. Counc. Energy Miner. Resour., Earth Sci. Ser., 2:221-258.

Abbreviations for names of organizations and publication titles in ODP reference lists follow the style given in Chemical Abstracts Service Source Index (published by American Chemical Society). 
Duncan, R.A., Vallier, T., and Falvey, D.A., 1985. Volcanic episodes at 'Eua Tonga. In Scholl, D.W., and Vallier, T.L. (Eds.), Geology and Offshore Resources of Pacific Island Arcs-Tonga Region. Circum-Pac. Counc. Energy Miner. Resour., Earth Sci. Ser., 2:281-290.

Ewart, A., 1968. The petrography of the central north island rhyolitic lavas, part 2. Regional petrography including notes on associated ash-flow pumice deposits. N.Z. J. Geol. Geophys., 11:478-545.

- 1979. A review of the mineralogy and chemistry of Tertiary-Recent dacitic, latitic, rhyolitic and related salic volcanic rocks. In Barker, F. (Ed.), Trondhjemites, Dacites, and Related Rocks: Amsterdam (Elsevier), 13-121.

Ewart, A., Brothers, R.N., and Mateen, A., 1977. An outline of the geology and geochemistry, and the possible petrogenetic evolution of the volcanic rocks of the Tonga-Kermadec-New Zealand island arc. J. Volcanol. Geotherm. Res., 2:205-250.

Ewart, A., and Bryan, W., 1972. Petrography and geochemistry of the igneous rocks from 'Eua, Tonga Islands. Geol. Soc. Am. Bull., 83:3281-3298.

Ewart, A., and Hawkesworth, C.J., 1987. The Pleistocene-Recent Tonga-Kermadec arc lavas: interpretation of new isotope and rare earth data in terms of a depleted mantle source model. J. Petrol., 28:495-530.

Ewart, A., Schon, R.W., and Chappell, B.W., in press. The Cretaceous volcanic-plutonic province of the central Queensland (Australia) coast-a rift related "calc-alkaline" province. Trans. R. Soc. Edimburgh: Earth Sci.

Falloon, T.J., Green, D.H., and Crawford, A.J., 1987. Dredged igneous rocks from the northern termination of the Tofua magmatic arc, Tonga and adjacent Lau Basin. Aust. J. Earth Sci., 34:487-506.

Fedotov, S.A., 1978. Ascent of basic magmas in the crust and the mechanism of basaltic fissure eruptions. Int. Geol. Rev., 20:33-47.

Fisher, R.L., and Engel, C.G., 1969. Ultramafic and basaltic rocks dredged from the nearshore flank of the Tonga Trench. Geol. Soc. Am. Bull., 80:1373-1378.

Fryer, P., Ambos, E.L., and Hussong, D.M., 1985. Origin and emplacement of Mariana forearc seamounts. Geology, 13:774-777.

Fryer, P., and Fryer, G.J., 1987. Origins of nonvolcanic seamounts in a forearc environment. In Keating, B.H., Fryer, P., Batiza, R., and Boehlert, G.W. (Eds.), Seamounts, Islands, and Atolls. Am. Geophys. Union, Monogr. Ser., 43:61-72.

Ghiorso, M.S., and Carmichael, I.S.E., 1981. A Fortran IV computer program for evaluating temperatures and oxygen fugacities from the compositions of coexisting iron-titanium oxides. Comput. Geosci., 7:123-129.

Gnibidenko, H.S., Anosov, G.I., Argentov, V.V., and Pushchin, I.K., 1985. Tectonics of the Tonga-Kermadec Trench and Ozbourn Seamount junction area. Tectonophysics, 112:357-383.

Green, D.H., 1973. Experimental melting studies on a model upper mantle composition at high pressure under water-saturated and water-undersaturated conditions. Earth Planet. Sci. Lett., 19:37-53.

Greene, H.G., and Wong, F.L., 1983. Hydrocarbon resource studies of the southwestern Pacific, 1982. Open File Rep.-U.S. Geol. Surv., 82-293.

Haggerty, J.A., 1987. Petrology and geochemistry of Neogene sedimentary rocks from Mariana forearc seamounts: implications for emplacement of the seamounts. In Keating, B., Fryer, P., Batiza, R., and Boehlert, G.W. (Eds.), Seamounts, Islands, and Atolls. Am. Geophys. Union., Geophys. Monogr. Ser., 43:175-185.

Hawkins, J.W., and Falvey, D.A., 1985. Petrology of andesitic dikes and flows from 'Eua, Tonga. In Scholl, D.W., and Vallier, T.L. (Eds.), Geology and Offshore Resources of Pacific Island Arcs-Tonga Region. Circum-Pac. Counc. Energy Miner. Resour., Earth Sci. Ser., 2:269-280.

Helz, R.T., 1976. Phase relations of basalts in their melting ranges at $\mathrm{pH}_{2} \mathrm{O}=$ 5kb. Part II. Melt compositions. J. Petrol., 17:139-193.

Herzer, R.H., and Exon, N.F., 1985. Structure and basin analysis of the southern Tonga forearc. In Scholl, D.W., and Vallier, T.L. (Eds.), Geology and Offshore Resources of Pacific Island Arcs-Tonga Region. CircumPac. Counc. Energy Miner. Resour., Earth Sci. Ser., 2:55-73.

Hussong, D.M., and Uyeda, S., 1982. Tectonic processes and the history of the Mariana Arc: a synthesis of the results of Deep Sea Drilling Project Leg 60. In Hussong, D.M., Uyeda, S., et al., Init. Repts. DSDP, 60: Washington (U.S. Govt. Printing Office), 909-929.

Ishii, T., 1985. Dredged samples from the Ogasawara fore-arc seamount or "Ogasawara paleoland"-"fore-arc ophiolite." In Nasu, N., Kobayashi, K., Kushiro, I., Kagami, H. (Eds.), Formation of Active Ocean Margins: Tokyo (Terra Sci. Publ.), 307-342.

James, R.S., and Hamilton, D.L., 1969. Phase relations in the system NaAISi $\mathrm{O}_{8-}$ $\mathrm{CaAl}_{2} \mathrm{O}_{8}-\mathrm{SiO}_{2}$ at I kilobar water vapour pressure. Contrib. Mineral. Petrol., 21:111-141.
Johnson, L.E., Fryer, P., Taylor, B., Silk, M., Jones, D.L., Sliter, W.V.. Itaya, T., and Ishii, T., 1991. New evidence for crustal accretion in the outer Mariana forearc: Cretaceous radiolarian cherts and MORB-like lavas. Geology, 19:811-814.

Karig, D.E., and Ranken, D., 1983. Marine geology of the forearc region, southern Mariana island arc. In Hayes, D.E. (Ed.), The Tectonic and Geologic Evolution of Southeast Asian Seas and Islands (Pt. 2). Am. Geophys. Union, Monogr. Ser., 27:266-280.

Lagabrielle, Y., Sizun, J.-P., and Arculus, R.J., 1992. The constructional and deformational history of the igneous basement penetrated at Site 786. In Fryer, P., Pearce, J.A., Stokking, L.B., et al., Proc. ODP, Sci. Results, 125: College Station, TX (Ocean Drilling Program), 263-276.

Le Bas, M.J., Le Maitre, R.W., Streckeisen, A., and Zanettin, B., 1986. A chemical classification of volcanic rocks based on the total alkali-silica diagram. J. Petrol., 27:745-750.

Lonsdale, P., 1986. A multibeam reconnaissance of the Tonga Trench axis and its intersection with Louisville Guyot Chain. Mar. Geophys. Res., 8:295-327.

Malahoff, A., Feden, R., II, and Fleming, H.S., 1982. Magnetic anomalies and tectonic fabric of marginal basins north of New Zealand. J. Geophys. Res., 87:4109-4125.

Marlow, M.S., Johnson, L.E., Pearce, J.A., Fryer, P.B., Pickthorn, L.G., and Murton, B.J., 1992. Pleistocene volcanic rocks in the Mariana forearc revealed by drilling at Site 781. In Fryer, P., Pearce, J.A., Stokking, L.B., et al., Proc. ODP, Sci. Results, 125: College Station, TX (Ocean Drilling Program), 293-310.

Meijer, A., 1980. Primitive island arc volcanism and a boninite series: examples from the western Pacific island arc system. In Hayes, D.E. (Ed.), Tectonic and Geologic Evolution of Southwest Asian Seas and Islands. Am. Geophys. Union, Geophys. Monogr. Ser., 23:269-282.

, 1983. The origin of low- $\mathrm{K}$ rhyolites from the Mariana frontal arc. Contrib. Mineral. Petrol., 83:45-51.

Mottl, M.J., Haggerty, J.A., and Scientific Party of Ocean Drilling Program Leg 125, 1989. Upwelling of $\mathrm{Cl}$-poor, $\mathrm{S}$-, and $\mathrm{C}$-rich waters through a serpentinite seamount, Mariana Forearc: ODP Leg 125. Eos, 70:1382.

Mrozowski, C.L., and Hayes, D.E., 1980. A seismic reflection study of faulting in the Mariana fore arc. In Hayes, D.E. (Ed.), The Tectonic and Geologic Evolution of Southeast Asian Seas and Islands. Am. Geophys. Union, Geophys. Monogr. Ser., 23:223-234.

Murton, B.J., Peate, D.W., Arculus, R.J., Pearce, J.A., and van der Laan, S., 1992. Trace-element geochemistry of volcanic rocks from Site 786: the Izu-Bonin forearc. In Fryer, P., Pearce, J.A., Stokking, L.B., et al., Proc. ODP, Sci. Results, 125: College Station, TX (Ocean Drilling Program), 211-235.

Natland, J.H., and Tarney, J., 1982. Petrologic evolution of the Mariana arc and back-arc basin system-a synthesis of drilling results in the South Philippine Sea. In Hussong, D.M., Uyeda, S., et al., Init. Repts. DSDP, 60: Washington (U.S. Govt. Printing Office), 877-908.

Nekvasil, H., 1988. Calculated effect of anorthite component on the crystallization paths of $\mathrm{H}_{2} \mathrm{O}$-undersaturated haplogranitic melts. Am. Mineral., 73:966-982.

Packham, G.H., 1985. Vertical tectonics on the Tonga Ridge from the Tongatapu oil exploration wells. In Scholl, D.W., and Vallier, T.L. (Eds.), Geology and Offshore Resources of Pacific Island Arcs-Tonga Region. Circum-Pac. Counc. Energy Miner. Resour., Earth Sci. Ser., 2:291-300.

Parson, L., Hawkins, J., Allan, J., et al., 1992. Proc. ODP, Init. Repts., 135: College Station, TX (Ocean Drilling Program).

Pearce, J.A., Lippard, S.J., and Roberts, S., 1984. Characteristics and tectonic significance of supra-subduction zone ophiolites. In Kokelaar, B.P., and Howells, M.F. (Eds.), Marginal Basin Geology. Geol. Soc. Spec. Publ. London, 16:74-94.

Pearce, J.A., Thirlwall, M.F., Ingram, G., Murton, B.J., Arculus, R.J., and van der Laan, S.R., 1992. Isotopic evidence for the origin of boninites and related rocks drilled in the Izu-Bonin (Ogasawara) forearc, Leg 125. In Fryer, P., Pearce, J.A., Stokking, L.B., et al., Proc. ODP, Sci. Results, 125: College Station, TX (Ocean Drilling Program), 237-261.

Pelletier, B., and Louat, R., 1989. Seismotectonics and present day relative plate motions in the Tonga-Lau and Kermadec-Havre region. Tectonophysics, 165:237-250.

Philpotts, A.R., 1990. Principles of lgneous and Metamorphic Petrology: Englewood Cliffs, NJ (Prentice Hall).

Philpotts, A.R., and Martello, A., 1986. Diabase feeder dikes for the Mesozoic basalts in southern New England. Am. J. Sci., 286:105-126.

Raitt, R.W., Fisher. R.L., and Mason, R.G., 1955. Tonga Trench. In Poldervaart, A. (Ed.), Crust of the Earth. Spec. Pap.-Geol. Soc. Am., 62:237-254. 
Reagan, M.K., and Meijer, A., 1984. Geology and geochemistry of early arc volcanic rocks from Guam. Geol. Soc. Am. Bull., 95:701-713.

Ringwood. A.E., 1974. The petrological evolution of island arc systems. J. Geol. Soc. London, 130:183-204.

Robertson, A.H.F., 1990. Tectonic evolution of Cyprus. In Malpas, J., Moores, E.M., Panayiotou, A., and Xenophontos, C. (Eds.), Ophiolites: Oceanic Crustal Analogues, Proc. Symp. "TROODOS 1987." Cyprus Geol. Surv. Dep., 235-249.

Schmidt, R.G.. 1957. Petrology of the volcanic rocks. In Cloud, P.E., et al., Geology of Saipan, Mariana Islands (Pt. 2, Chapt. B). Geol. Surv. Prof. Pap. U.S., 280:127-172.

Sharaskin, A.Y., Pustchin, 1.K., Zlobin, S.K., and Kolesov, G.M., 1983. Two ophiolitic sequences from the basement of the northern Tonga Arc. Ofioliti, $8: 411-430$.

Shipboard Scientific Party, 1990a. Site 781. In Fryer, P., Pearce, J.A., Stokking. L.B., et al., Proc. ODP, Init. Repts., 125: College Station, TX (Ocean Drilling Program), 179-195.

1990b. Site 793. In Taylor, B.. Fujioka, K.., et al.. Proc. ODP, Init. Repts., 126: College Station. TX (Ocean Drilling Program). 315-403. . 1992. Site 841. In Parson, L.. Hawkins, J., Allan. J., et al., Proc. $O D P$, Init. Repts., 135: College Station, TX (Ocean Drilling Program), $571-677$.

Stern, R.J., and Bloomer, S.H., 1992. Subduction zone infancy: examples from the Eocene Izu-Bonin-Mariana and Jurassic California Arcs. Geol. Soc. Am. Bull., 104:1621-1636.

Stern, R.J.. Morris, J., Bloomer, S.H., and Hawkins, J.W., 1991. The source of the subduction component in convergent margin magmas: trace element and radiogenic isotope evidence from Eocene boninites, Mariana forearc. Geochim. Cosmochim. Acta, 55:1467-1481.

Stormer, J.C., Jr., 1983. The effects of recalculation on estimates of temperature and oxygen fugacity from analyses of multicomponent iron-titanium oxides. Am. Mineral., 68:586-594.

Sun, S.-S., and McDonough, W.F., 1989. Chemical and isotopic systematics of oceanic basalts: implications for mantle composition and processes. In Saunders, A.D., and Norry, M.J. (Eds.). Magmatism in the Ocean Basins. Geol. Soc. Spec. Publ. London, 42:313-345.

Taylor, B., 1992. Rifting and the volcanic-tectonic evolution of the Izu-BoninMariana Arc. In Taylor, B., Fujioka, K., et al., Proc. ODP, Sci. Results. 126: College Station, TX (Ocean Drilling Program), 627-651.
Taylor, R.N., Lapierre, H., Vidal, P., Nesbitt, R.W., and Croudace, I.W., 1992. Igneous geochemistry and petrogenesis of the Izu-Bonin forearc basin. In Taylor, B., Fujioka, K., et al., Proc. ODP. Sci. Results, 126: College Station, TX (Ocean Drilling Program), 405-430.

Tsunakawa, H., 1983. K-Ar dating on volcanic rocks in the Bonin Islands and its tectonic implication. Tectonophysics, 95:221-232.

Umino, S., 1985. Volcanic geology of Chichijima, the Bonin Islands (Ogasawara Islands). Chishitsugaku Zasshi [J. Geol. Soc. Jpn.], 91:505-523.

Vallier, T.L., O'Connor, R.M., Scholl, D.W., Stevenson, A.J., and Quinterno, P.J., 1985. Petrology of rocks dredged from the landward slope of the Tonga Trench: implications for middle Miocene volcanism and subsidence of the Tonga Ridge. In Scholl. D., and Vallier, T.L. (Eds.), Geology and Offshore Resources of Pacific Island Arcs-Tonga Region. Circum-Pac. Counc. Energy Miner. Resour., Earth Sci. Ser., 2:109-120.

Vallier, T.L., Stevenson, A.J., and Scholl, D.W., 1985. Petrology of igneous rocks from 'Ata Island, Kingdom of Tonga. In Scholl, D.W., and Vallier, T.L. (Eds.), Geology and Offshore Resources of Pacific Island ArcsTonga Region. Circum-Pac. Counc. Energy Miner. Resour., Earth Sci. Ser., 2:301-316.

van der Laan, S.R., Flower, M.F.J., and Koster van Groos, A.F., 1989. Experimental evidence for the origin of boninites: near-liquidus phase relations to 7.5 kbar. In Crawford, A.J. (Ed.), Boninites and Related Rocks: London (Unwin Hyman), 112-147.

van der Lingen, G., 1973. The Lord Howe Rise rhyolites. In Burns, R.E., Andrews, J.E., et al., Init. Repts. DSDP, 21: Washington (U.S. Govt. Printing Office), 523-540.

Wood, D.A., Mattey, D.P., Joron, J.L., Marsh, N.G., Tarney, J., and Treuil, M., 1981. A geochemical study of 17 selected samples from basement cores recovered at Sites 447, 448, 449, 450, and 451, Deep Sea Drilling Project Leg 59. In Kroenke, L., Scott, R., et al., Init. Repts. DSDP, 59: Washington (U.S. Govt. Printing Office), 743-752.

Date of initial receipt: 22 June 1992

Date of acceptance: 7 June 1993

Ms 135SR-129 